\title{
Simulation of Ground-Water Flow in the Saginaw Aquifer, Clinton, Eaton, and Ingham Counties, Michigan
}

By DAVID J. HOLTSCHLAG, C.L. LUUKKONEN, and J.R. NICHOLS

Prepared in cooperation with the

TRI-COUNTY REGIONAL PLANNING COMMISSION 


\title{
U.S. DEPARTMENT OF THE INTERIOR BRUCE BABBITT, Secretary
}

\author{
U.S. GEOLOGICAL SURVEY \\ Gordon P. Eaton, Director
}

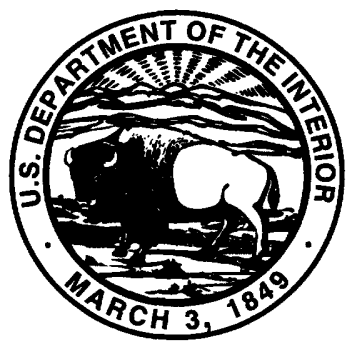

Any use of trade, product, or firm names in this publication is for descriptive purposes only and does not imply endorsement by the U.S. Government.

Printed in the Eastern Region, Reston, Va.

UNITED STATES GOVERNMENT PRINTING OFFICE, WASHINGTON : 1996

For sale by the

U.S. Geological Survey

Branch of Information Services

Box 25286

Denver, CO 80225

\author{
Library of Congress Cataloging in Publication Data \\ Holtschlag, David J. \\ Simulation of ground-water flow in the Saginaw Aquifer, Clinton, Eaton, and \\ Ingham Counties, Michigan / by D.J. Holtschlag, C.L. Luukkonen, and \\ J.R. Nicholas. \\ 49 p. cm. -- (U.S. Geological Survey water-supply paper ; 2480) \\ "Prepared in cooperation with Tri-County Regional Planning Commmission." \\ Includes bibliographical references (p. 48-49) \\ Supt. of Docs. no.: I 18.13: \\ 1. Groundwater flow--Michigan--Simulation methods. 2. Saginaw Aquifer \\ (Mich.) I. Luukkonen, C.L., (Carol L.) II. Nicholas, J.R. III. Tri-county Regional \\ Planning Commission (Mich.) IV. Title, V. Series. \\ GB1197.7H66 1996 \\ 551.49'09774'2--dc20
}




\section{CONTENTS}

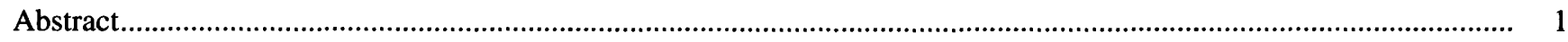

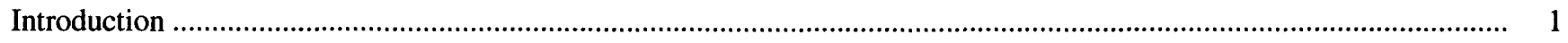

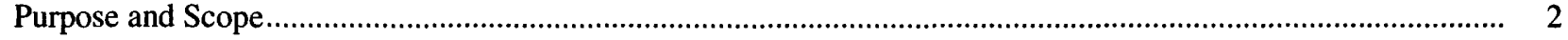

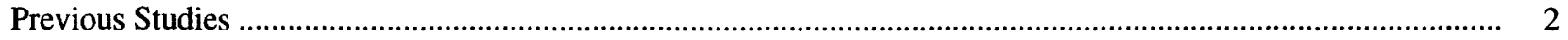

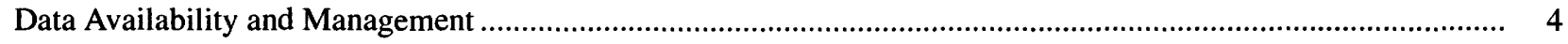

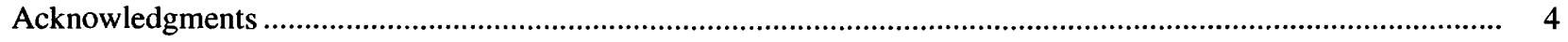

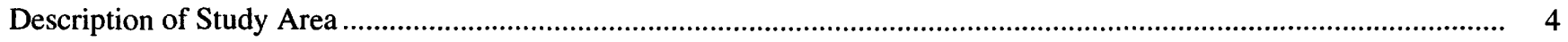

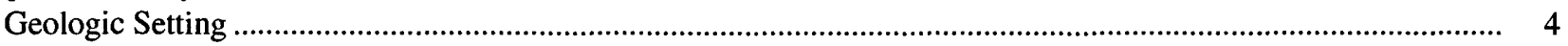

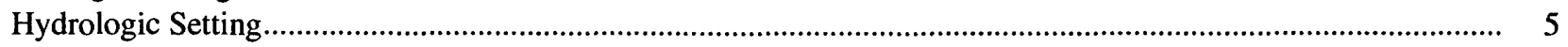

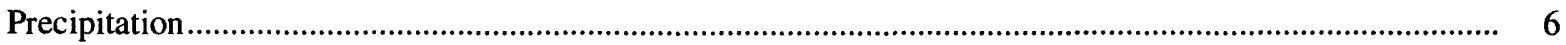

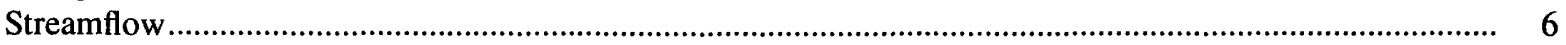

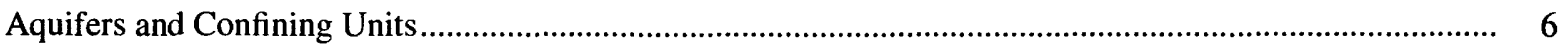

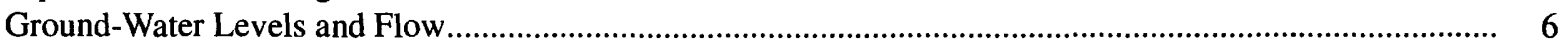

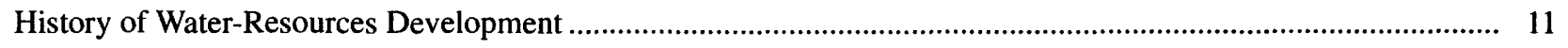

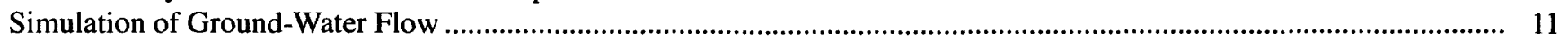

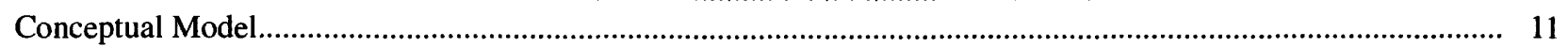

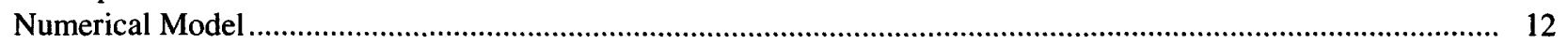

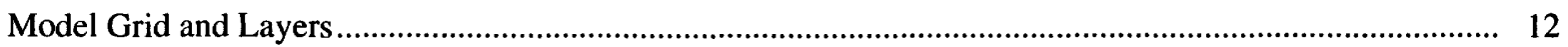

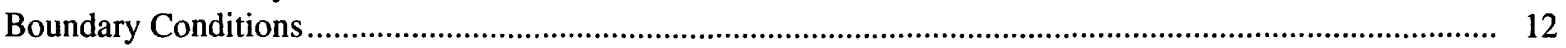

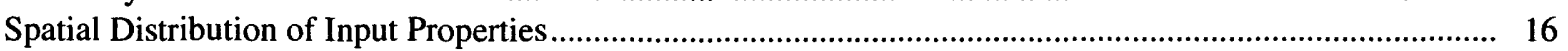

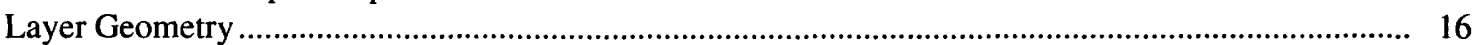

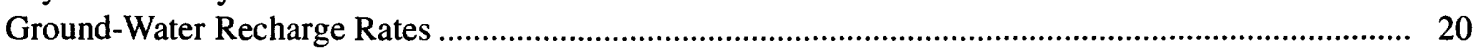

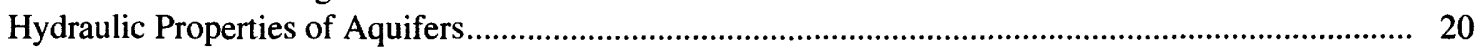

Transmissivity of the Saginaw Aquifer ............................................................................ 20

Horizontal Hydraulic Conductivity of the Glacial Deposits ............................................... 20

Vertical Hydraulic Conductivity .............................................................................. 24

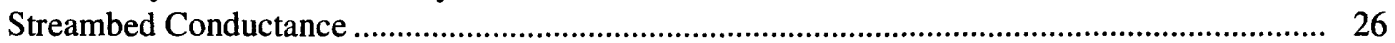

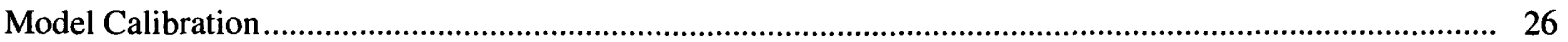

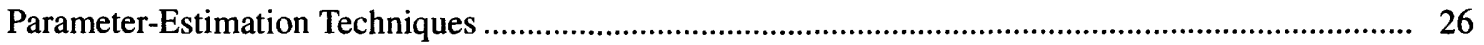

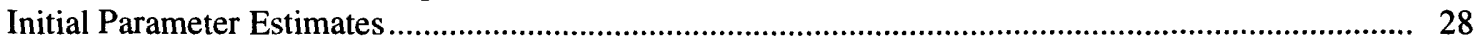

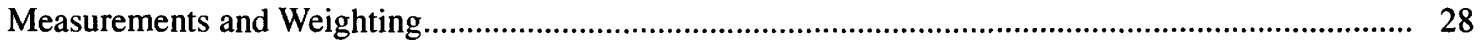

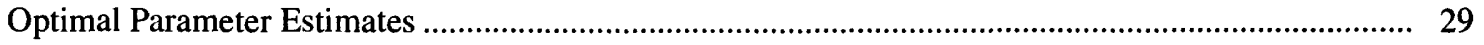

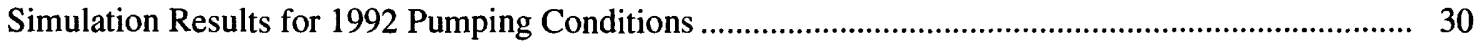

Ground-Water Heads ......................................................................................... 30

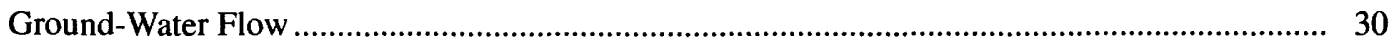

Expected Future Pumping Conditions ............................................................................... 34

Delineation of Contributing Areas ..................................................................................................... 38

Use of Tritium Data to Confirm Particle-Tracking Results ..........................................................................

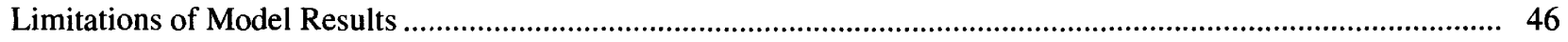

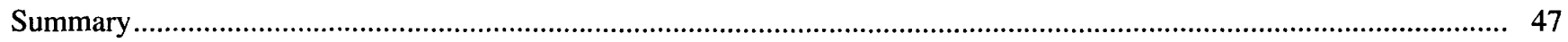

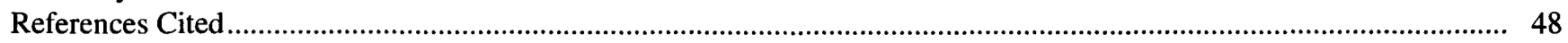




\section{FIGURES}

1,2. Maps showing locations of:

1. The Tri-County region in the Lower Peninsula of Michigan.

2. Active public-supply wells in 1992 , Tri-County region, Michigan

3. Diagram showing stratigraphic nomenclature and hydrogeologic units, Tri-County region, Michigan

4-6. Maps showing locations of:

4. Streamflow-gaging stations used in the analysis of ground-water flow, Tri-County region, Michigan.

5. Wells screened in the glacial deposits in the Tri-County region, Michigan, in which water levels were measured only once

6. Wells completed in the Saginaw aquifer in the Tri-County region, Michigan, in which water levels were measured one or more times

7. Graph showing ground-water withdrawals and population, Lansing, Michigan, 1910-90

8. Chart showing sources of water for public supply, Tri-County region, Michigan

9-10. Maps showing:

9. Ground-water levels in the glacial deposits in the model area, Tri-County region, Michigan

10. Ground-water levels in the Saginaw aquifer in the model area, Tri-County region, Michigan.

11. Diagram showing grid and upper-layer boundary conditions for the model area, Tri-County region, Michigan

12-15. Maps showing:

12. Estimated land-surface altitude in the model area, Tri-County region, Michigan.

13. Altitude of the bottom of the upper model layer, Tri-County region, Michigan

14. Altitude of the bottom of the lower model layer, Tri-County region, Michigan

15. Spatial variation of average ground-water recharge in the model area, Tri-County region, Michigan.

16. Box plots showing distribution of effective horizontal hydraulic conductivities in the glacial deposits

in the model area, Tri-County region, Michigan

17. Variogram of effective horizontal hydraulic conductivity in the glacial deposits, computed on

the basis of wells logged by driller $I 2$ in the model area, Tri-County region, Michigan.

18. Box plots showing distribution of effective vertical hydraulic conductivities in the glacial deposits in the model area, Tri-County region, Michigan

19. Variogram of effective vertical hydraulic conductivity in the glacial deposits, computed on the basis of wells logged by driller $B$ in the model area, Tri-County region, Michigan Maps showing:

20. Distribution of stream size classes in the model area, Tri-County region, Michigan.

21. Estimated transmissivity of the Saginaw aquifer in the model area, Tri-County region, Michigan

22. Estimated horizontal hydraulic conductivity in the glacial deposits in the model area,

Tri-County region, Michigan.

20-23.

23. Estimated vertical hydraulic conductivity between the Saginaw aquifer and the glacial deposits in the model area, Tri-County region, Michigan

24-25. Graphs showing:

24. Relation between measured and simulated heads in cells in the glacial deposits,

Tri-County region, Michigan.

25. Relation between measured and simulated heads in cells in the Saginaw aquifer, Tri-County region, Michigan.

26-27. Maps showing:

26. Simulated heads in the glacial deposits for 1992 pumping conditions in the model area, Tri-County region, Michigan.

27. Simulated heads in the Saginaw aquifer for 1992 pumping conditions in the model area, Tri-County region, Michigan.

28. Graph showing relation between measured and simulated streamflow, Tri-County region, Michigan

29. Diagram showing ground-water model budget components for 1992 pumping conditions, Tri-County region, Michigan 
30-35. Maps showing :

30. Simulated changes in water levels in the lower layer from 1992 conditions in the model area,

Tri-County region, Michigan, resulting from implementation of scenario 1

31. Simulated changes in water levels in the lower layer from 1992 conditions in the model area, Tri-County region, Michigan, resulting from implementation of scenario 2 .

32. Simulated changes in water levels in the lower layer from 1992 conditions in the model area, Tri-County region, Michigan, resulting from implementation of scenario 3.

33. Simulated contributing areas of public-supply wells in the nine-township area, Tri-County region, Michigan

34. Simulated 40 -year time-of-travel areas for public-supply wells in the nine-township area, Tri-County region, Michigan

35. Tritium concentrations and particle-tracking results for sampled wells in the model area, Tri-County region, Michigan

\section{TABLES}

1. Continuous-record streamflow-gaging stations in the Tri-County region, Michigan, used in the analysis of ground-water flow

2. Partial-record streamflow-gaging stations in the Tri-County region, Michigan, used in the analysis

of ground-water flow

3. Estimated hydraulic conductivities associated with strata codes in the statewide ground-water data base of Michigan.

4. Parameters for models of sample variogram of hydraulic conductivity, Tri-County region, Michigan.

5. Parameter estimates for coefficients multiplying matrices that describe the spatial variation of hydraulic properties, Tri-County region, Michigan.

\section{CONVERSION FACTORS AND VERTICAL DATUM}

\section{CONVERSION FACTORS}

\begin{tabular}{rll}
\hline Multiply & By & To obtain \\
\hline cubic foot per second $\left(\mathrm{ft}^{3} / \mathrm{s}\right)$ & 0.02832 & cubic meter per second \\
foot $(\mathrm{ft})$ & 0.3048 & meter \\
foot per day $(\mathrm{ft} / \mathrm{d})$ & 0.3048 & meter per day \\
foot squared per day $\left(\mathrm{ft}^{2} / \mathrm{d}\right)$ & 0.09290 & meter squared per day \\
inch (in.) & 25.4 & millimeter \\
inch per year (in/yr) & 25.4 & millimeter per year \\
mile $(\mathrm{mi})$ & 1.609 & kilometer \\
million gallons per day $\left(\mathrm{Mgal}^{2} \mathrm{~d}\right)$ & 3,785 & cubic meter per day \\
square mile $\left(\mathrm{mi}^{2}\right)$ & 2.590 & square kilometer \\
\hline
\end{tabular}

\section{VERTICAL DATUM}

Sea level: In this report, "sea level" refers to the National Geodetic Vertical Datum of 1929-a geodetic datum derived from a general adjustment of the first-order level nets of the United States and Canada, formerly called Sea Level Datum of 1929. 


\title{
Simulation of Ground-Water Flow in the Saginaw Aquifer, Clinton, Eaton, and Ingham Counties, Michigan
}

\author{
By D.J. Holtschlag, C.L. Luukkonen, and J.R. Nicholas
}

\section{Abstract}

A numerical model was developed to simulate ground-water flow in the Tri-County region, which consists of Clinton, Eaton, and Ingham Counties, Michigan. This region includes a nine-township area surrounding Lansing, Michigan. The model simulates the regional response of the Saginaw aquifer to major groundwater withdrawals associated with public-supply wells. The Saginaw aquifer, which is in the Grand River and Saginaw Formations of Pennsylvanian age, is the primary source of ground water for TriCounty residents. The Saginaw aquifer is overlain by glacial deposits, which also are important ground-water sources in some locations.

Flow in the Saginaw aquifer and the glacial deposits is simulated by discretizing the flow system into model cells arranged in two layers. Each cell, which corresponds to a land area of 0.0625 square mile, represents the locally averaged properties of the system. The spatial variation of hydraulic properties controlling ground-water flow was estimated by geostatistical analysis of 4,947 well logs. Parameter estimation, a form of nonlinear regression, was used to calibrate the flow model.

Results of steady-state ground-water-flow simulations show close agreement between water flowing into and out of the model area for 1992 pumping conditions; standard error of the difference between simulated and measured heads is $\mathbf{1 4 . 7}$ feet. Simulation results for three alternative pumping scenarios for the year 2020 show that the glacial aquifer could be dewatered in places if hypothetical increases in pumping are not distributed throughout the Tri-County region.

Contributing areas to public-supply wells in the nine-township area were delineated by a particle-tracking analysis. These areas cover about 121 square miles. Contributing areas for particles having travel times of 40 years or less cover about 42 square miles. Results of tritium sampling support results of model simulations to delineate contributing areas.

\section{INTRODUCTION}

The Tri-County region, which consists of Clinton, Eaton, and Ingham Counties, covers 1,697 $\mathrm{mi}^{2}$ in the south-central part of the Lower Peninsula of Michigan (fig. 1). The 432,700 people (U.S.

Department of Commerce, 1991) who live in this region rely on withdrawals of about $40.8 \mathrm{Mgal} / \mathrm{d}$ from ground-water sources. The primary source of ground water in the Tri-County region is the Saginaw aquifer, which is in the Grand River and Saginaw Formations of Pennsylvanian age. Aquifers in the glacial deposits and other bedrock units are also important groundwater sources in some places.

In 1988, the Tri-County Regional Planning Commission (TCRPC) began a series of studies to assess the regional water supply and distribution system. As part of this effort, the U.S. Geological Survey (USGS) entered into a cooperative agreement with TCRPC and a coalition of 22 communities who supported a 4-year study of ground-water flow and contributing areas of public-supply wells in the TriCounty region. Participating communities include Alaiedon Township, Bath Township, Delhi Township, 


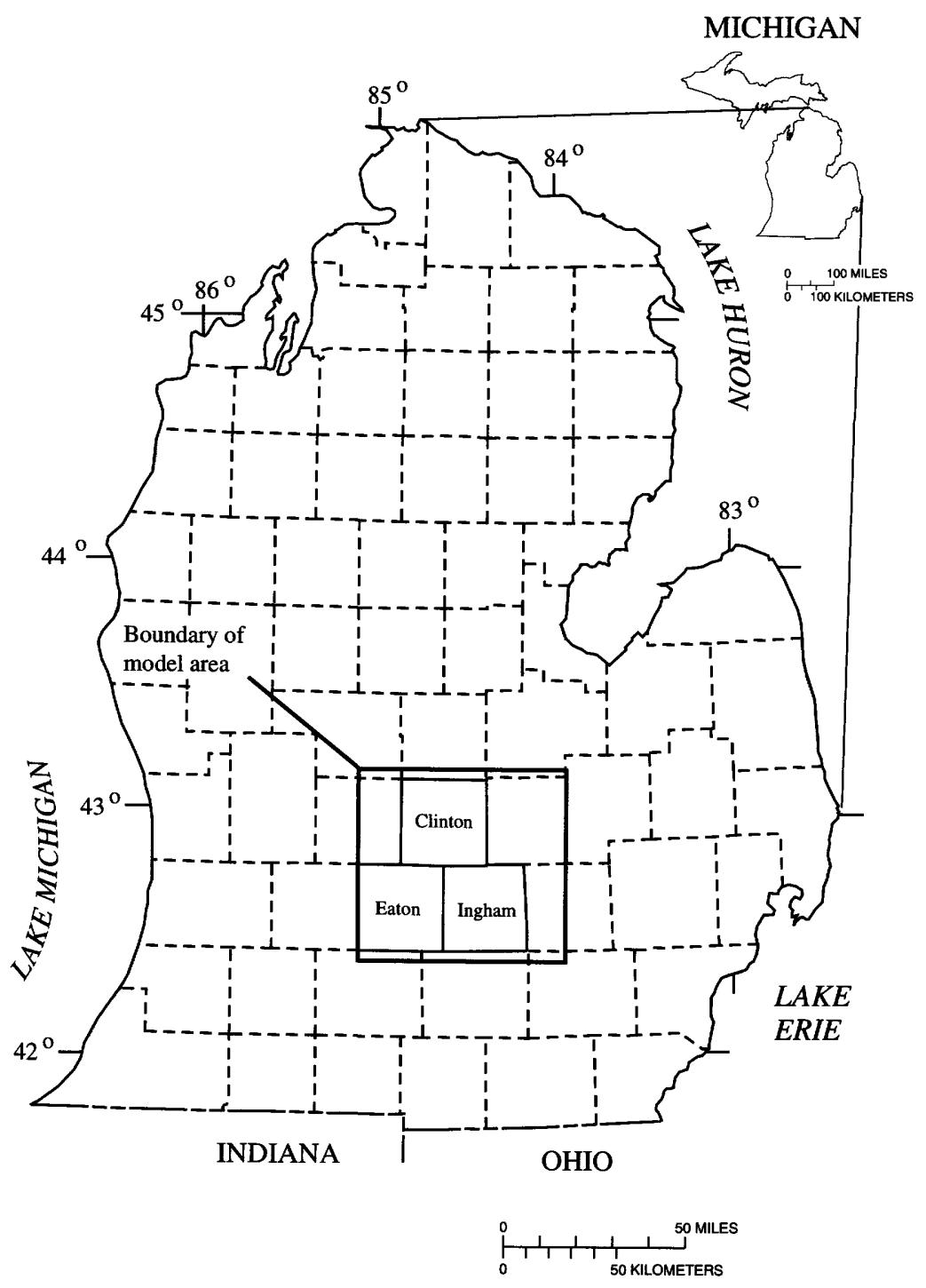

Figure 1. The Tri-County region in the Lower Peninsula of Michigan.

Delta Township, Dewitt Township, City of Dewitt, City of Dimondale, City of East Lansing, City of Grand Ledge, City of Lansing, Lansing Township, City of Mason, Michigan State University (MSU), Meridian Township, Oneida Township, Vevay Township, Watertown Township, Wheatfield Township, Williamstown Township, City of Williamston, Windsor Township, and Village of Webberville (fig. 2). In this report, the area surrounding Lansing, Mich. that is referred to as the nine-township area consists of Alaiedon, Bath, Delhi, Delta, Dewitt, Lansing, Meridian, Watertown, and Windsor Townships; this is the principal area of ground-water withdrawals in the Tri-County region.

\section{Purpose and Scope}

This report describes the simulation of ground-water flow in the Saginaw aquifer in the Tri-County region. The conceptual model of the hydrologic system is based on interpretation of new and previously available hydrogeologic data. The numerical model, which was developed from the conceptual model, simulates regional steady-state response of the Saginaw aquifer to major groundwater withdrawals from public-supply wells in 1992. Simulation results show how the model can be used to evaluate alternative ground-water pumping scenarios. Particle-tracking analysis was used with results from flow simulations to delineate contributing areas of publicsupply wells. Tritium concentrations in ground-water samples and corresponding ground-water ages were compared with delineations of 40 -year time-of-travel contributing areas. The limitations of the model for assessing ground-water levels and flow and for delineating contributing areas of wells are described.

\section{Previous Studies}

Previous studies contributed to the knowledge of the ground-water resources in the Tri-County region and were helpful to the authors of this report. Wheeler (1967) developed an electric analog model of ground-water flow in the Saginaw Formation in the Lansing, Mich. area. Wood (1969) describes the hydrogeology and geochemistry of ground water in the Saginaw Formation. Vanlier and others (1973) describe watersupply development and management alternatives in the Tri-County region. And recently, the Tri-County Regional Planning Commission (1992) completed a regional feasibility study on watersupply development. 


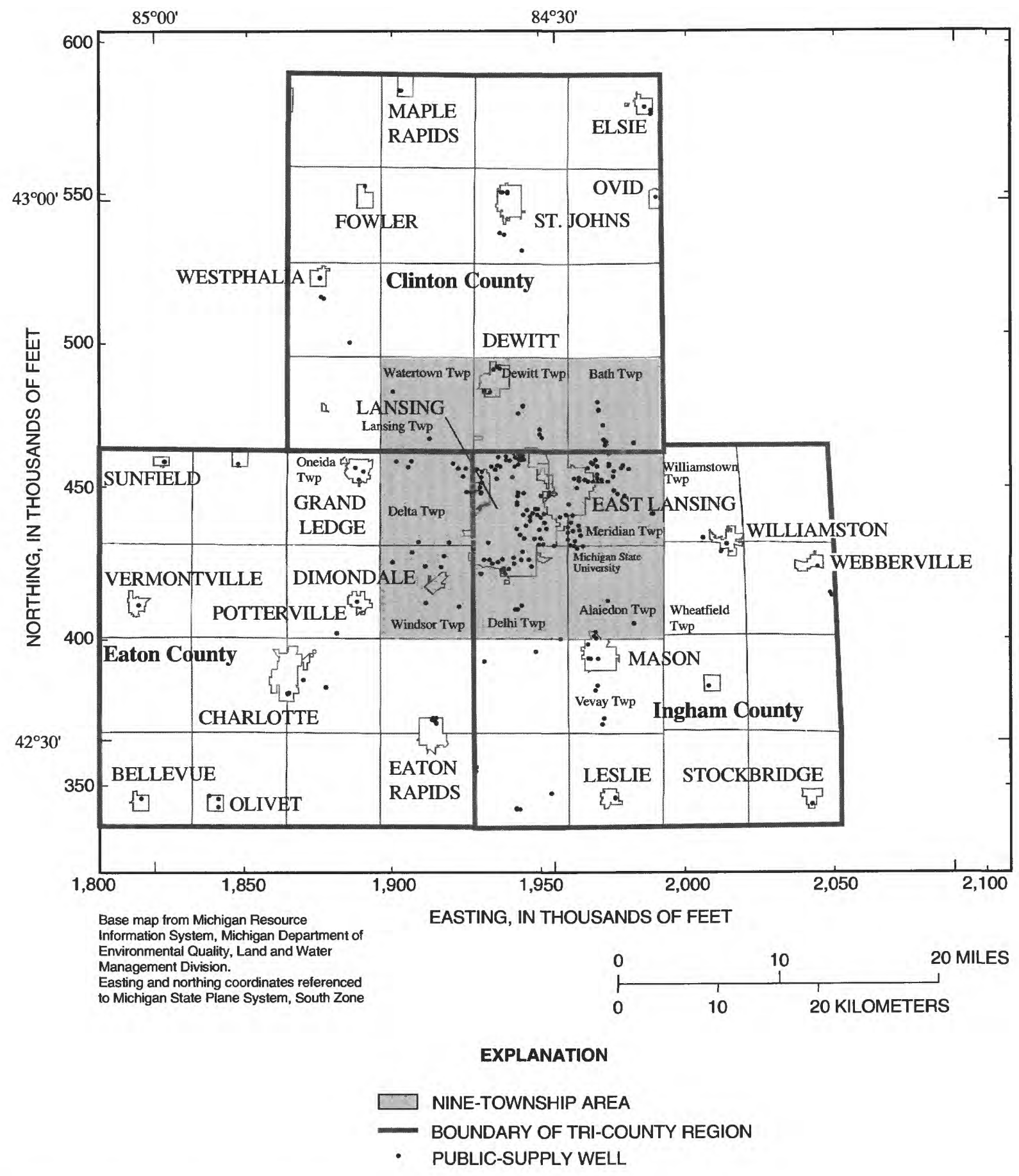

Figure 2. Active public-supply wells in 1992, Tri-County region, Michigan. 
Five reports that document computer programs were used in this study of the Grand River and Saginaw Formations. A report by McDonald and Harbaugh (1988) documents the USGS modular ground-water flow model (MODFLOW). A report by Geraghty and Miller (1993) documents the use of the MODELCAD ${ }^{1}$ program, which was used to aid the preparation of the model grid and input data. A report by Hill (1992) documents the parameter-estimation technique (MODFLOWP) applied to the ground-water-flow model. A report by Pollock (1989) documents a particle-tracking postprocessing program called MODPATH, which computes pathlines based on output from the modular model. Finally, a report by Harbaugh (1990) documents the computer program ZONEBUDGET, which calculates subregional water budgets based on results from MODFLOW.

\section{Data Availability and Management}

Model input and output data will be archived at the office of the USGS in Lansing, Mich. An electronic copy of this report and the data input and output files needed to use the ground-water-flow model will be archived to facilitate public access.

\section{Acknowledgments}

The authors gratefully acknowledge the assistance of Jon Coleman, Executive Director of TCRPC, and Sue McCormick, Manager, Water Technical Support Service, Lansing Board of Water and Light, for providing data on anticipated ground-water withdrawals (data used for simulating future pumping conditions); Christine Spitzley, TCRPC, Hope Croskey and Debbie Spakoff, Michigan Department of Environmental Quality (MDEQ), and Brant Fisher, Michigan Department of Public Health, for their assistance in delineating contributing areas of public-supply wells; and Shirley Businski, Land and Water Management Division, MDEQ, for her assistance in providing logs of water wells. The authors also wish to thank the many public suppliers who contributed water-use information.

\footnotetext{
${ }^{1}$ Use of firm names in this report is for identification purposes only and does not constitute endorsement by the U.S. Geological Survey.
}

\section{DESCRIPTION OF STUDY AREA}

The study area is the Tri-County region, which is in the south-central part of the Lower Peninsula of Michigan. The primary geologic, hydrologic, and water-use characteristics that affect ground-water flow in the Saginaw aquifer are described in the following sections.

\section{Geologic Setting}

In the Tri-County region, sedimentary rocks of Devonian, Mississippian, and Pennsylvanian age overlie Precambrian crystalline rocks. Rocks of Triassic, [Lower and Middle] Jurassic, and Cretaceous age are missing (Mandle and Westjohn, 1988). Glacial deposits of Pleistocene age overlie Pennsylvanian [and Upper Jurassic] rocks (fig. 3).

Pennsylvanian rocks are the uppermost bedrock unit in the Tri-County region. Here the altitude of the surface of the Pennsylvanian rocks ranges from about $850 \mathrm{ft}$ in the south to about $600 \mathrm{ft}$ in the north. Pennsylvanian rocks are thickest in the west-central part of Clinton County, and they generally thin to the south. They are absent in the extreme eastern part of Ingham County.

Discontinuous lenses of sandstone, shale, coal, and limestone in the Pennsylvanian rocks have been formally subdivided into two formations. The uppermost massive, coarse-grained sandstones form the Grand River Formation; all remaining Pennsylvanian rocks, including the Parma Sandstone, are considered part of the underlying Saginaw Formation (Mandle and Westjohn, 1988, p. 89). These assignments are somewhat uncertain, however, because no lithologic differences or stratigraphic horizons mark a change from one formation to the next (Westjohn and Weaver, 1996).

Jurassic "red beds," which separate Pennsylvanian rocks from glacial deposits in some areas in the Lower Peninsula, are either entirely absent or only marginally present in the Tri-County region (Westjohn and others, 1994). Therefore, for the purpose of this study, all deposits between the top of the Pennsylvanian rocks and land surface were assumed to be glacial deposits.

Glacial features in Michigan are the result of ice advances during late Wisconsin time $(35,000$ to 10,000 years before the present). The thickness of 


\begin{tabular}{|c|c|c|c|}
\hline$\overleftrightarrow{\frac{z}{x}}$ & $\frac{\hat{2}}{2}$ & $\begin{array}{l}\text { STRATIGRAPHIC } \\
\text { NOMENCLATURE }\end{array}$ & $\begin{array}{l}\text { HYDROGEOLOGIC } \\
\text { UNIT } \\
\text { (general thickness range) }\end{array}$ \\
\hline 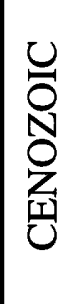 & 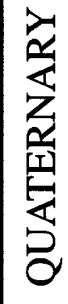 & $\begin{array}{l}\text { Glacial } \\
\text { deposits }\end{array}$ & $\begin{array}{l}\text { Aquifers in the } \\
\text { glacial deposits } \\
\text { (0-300 feet) }\end{array}$ \\
\hline \multirow{5}{*}{ 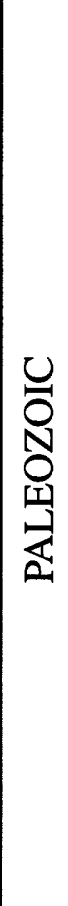 } & \multirow{2}{*}{ 觉 } & $\begin{array}{l}\text { Grand River } \\
\text { Formation }\end{array}$ & $\begin{array}{l}\text { Saginaw aquifer } \\
\quad(0-300 \text { feet })\end{array}$ \\
\hline & & \multirow{2}{*}{ 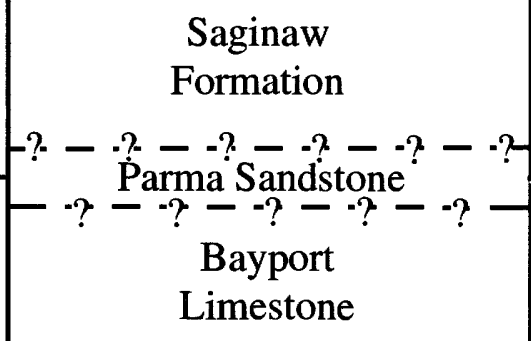 } & $\begin{array}{c}\text { Saginaw confining unit } \\
\text { (5-50 feet) }\end{array}$ \\
\hline & \multirow{3}{*}{ 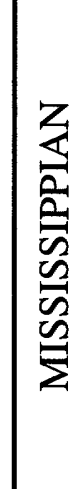 } & & $\begin{array}{l}\text { Parma-Bayport aquifer } \\
\quad(50-100 \text { feet })\end{array}$ \\
\hline & & $\begin{array}{l}\text { Michigan } \\
\text { Formation }\end{array}$ & $\begin{array}{l}\text { Michigan confining unit } \\
\quad(50-250 \text { feet })\end{array}$ \\
\hline & & $\begin{array}{l}\text { Marshall } \\
\text { Sandstone }\end{array}$ & $\begin{array}{l}\text { Marshall aquifer } \\
(100-150 \text { feet })\end{array}$ \\
\hline
\end{tabular}

Figure 3. Stratigraphic nomenclature and hydrogeologic units, Tri-County region, Michigan.

the glacial deposits in the Tri-County region ranges from 0 to $300 \mathrm{ft}$. Glacial deposits are absent in a small part of Grand Ledge; the thickest glacial deposits are in the northwestern part of the study area. The deposits range in texture from lacustrine clay or glacial till to coarse alluvial and outwash deposits. None of these deposits are regionally continuous (Mandle and Westjohn, 1988, p. 90).

\section{Hydrologic Setting}

For the purpose of developing a groundwater flow model, the hydrologic setting is characterized in terms of precipitation, streamflow characteristics, aquifers and confining units, and ground-water levels and flow. These elements of the hydrologic setting are discussed in the sections that follow. 


\section{Precipitation}

In the Tri-County region, precipitation is the ultimate source of ground-water and surface-water resources. In the region, mean precipitation ranges from a maximum of about $32 \mathrm{in} / \mathrm{yr}$ in the southwest to about $30 \mathrm{in} / \mathrm{yr}$ elsewhere (Eichenlaub and others, 1990 , p. 90). Precipitation is fairly evenly distributed throughout the year; June is the month of highest average precipitation ( 3.5 in.), and February is the month of lowest average precipitation (1.5 in.). The TriCounty region averages about $40 \mathrm{in} / \mathrm{yr}$ of snowfall. About $10 \mathrm{in} / \mathrm{yr}$ of precipitation in the region eventually becomes streamflow; the remainder is consumed by way of evaporation or transpiration, seepage to deep ground-water reservoirs, or other processes.

\section{Streamflow}

Most of the Tri-County region drains to the north and west into Grand River and its major tributaries which include Maple River, Looking Glass River, Red Cedar River, and Thornapple River (fig. 4). A small area in southeastern Ingham County drains to the east, and a small area in the southwestern part of Eaton County drains to the south.

Streamflow can be subdivided into direct-runoff and base-flow components. Direct runoff is associated with precipitation that exceeds soil infiltration capacity and flows overland directly into streams. Base flow is associated with precipitation that infiltrates the soil and percolates below the plant-rooting depth into the unsaturated zone below ground. Some of this percolating water joins deeper zones, which are permanently saturated. This water then flows to streams and sustains flow between periods of precipitation. In this report, water in these permanently saturated zones is referred to as "ground water."

Base-flow characteristics of streams were used to help determine the amount of precipitation that recharges ground water in the Tri-County region. Information about base flow at fixed locations along streams is provided by data obtained at continuousrecord and partial-record gaging stations. Continuousrecord stations provide daily mean streamflows for 1 or more years that can be used to develop streamflow hydrographs. Hydrograph-analysis techniques are commonly used to estimate the ground-water contribution to streamflow (Rutledge and Daniel, 1994). In this study, streamflow partitioning (Rutledge, 1993) was used to estimate the ground-water component by use of data from 10 continuous-record streamflow-gaging stations (table 1). Data from partial-record streamflow-gaging stations were used to supplement information at continuous-record stations. Instantaneous streamflow measurements were statistically related to daily mean streamflow at nearby continuous-record gaging stations by use of a maintenance of variance estimator (Hirsch, 1982, p. 1083). The estimates of base flow at partial-record stations are listed in table 2.

\section{Aquifers and Confining Units}

Glacial deposits are the uppermost aquifer in the Tri-County region. Aquifers in the glacial deposits are composed of coarse alluvial and outwash materials. Glacial deposits are in direct contact with the underlying Saginaw aquifer. The Saginaw aquifer is in water bearing sandstones in the Grand River and Saginaw Formations (fig. 3). Water is assumed to move slower through the shales and other tight materials than through the sandstone. The Saginaw aquifer underlies most of the Tri-County region and ranges in thickness from 0 to $300 \mathrm{ft}$. The Saginaw confining unit separates the Saginaw aquifer from underlying units. In the TriCounty region, the thickness of the Saginaw confining unit generally ranges from 5 to $50 \mathrm{ft}$, although lithologic logs for some wells indicate that the confining unit may be either locally absent or as much as $100 \mathrm{ft}$ thick (Westjohn and Weaver, 1996, fig. 7). For the purposes of this study, the Saginaw confining unit was assumed to hydraulically isolate the Saginaw aquifer from deeper aquifers.

\section{Ground-Water Levels and Flow}

The hydraulic head at a point in an aquifer can be estimated by measuring the depth to water in a well that is open only to that point in the aquifer. Groundwater levels in wells screened across the water surface indicate the position of the water table; wells tapping deeper parts of an aquifer indicate the composite hydraulic head over the screened or open interval. 


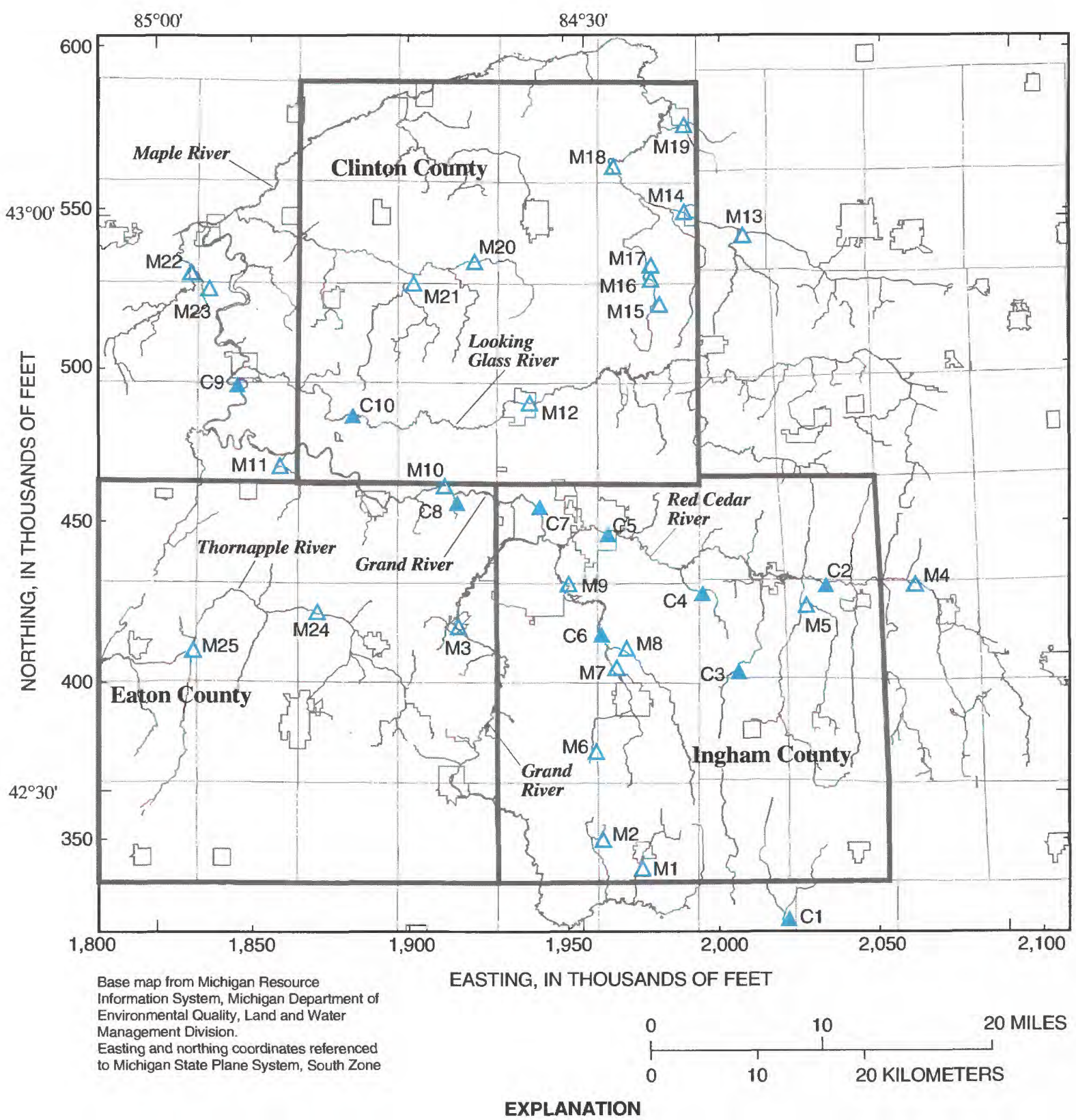

BOUNDARY OF TRI-COUNTY REGION

\section{$\triangle$ C1 CONTINUOUS-RECORD GAGING STATION \\ $\triangle \quad$ M1 PARTIAL-RECORD GAGING STATION}

Figure 4. Streamflow-gaging stations used in the analysis of ground-water flow, Tri-County region, Michigan. 
Table 1.Continuous-record streamflow-gaging stations in the Tri-County region, Michigan, used in the analysis of ground-water flow

\begin{tabular}{lllccc}
\hline $\begin{array}{c}\text { Map } \\
\text { index }\end{array}$ & $\begin{array}{c}\text { UsGS gaging } \\
\text { station No. }\end{array}$ & Station name & $\begin{array}{c}\text { Drainage } \\
\text { area } \\
\text { (square } \\
\text { miles) }\end{array}$ & $\begin{array}{c}\text { Period of } \\
\text { record }\end{array}$ & $\begin{array}{c}\text { Base flow } \\
\text { (cubic feet per } \\
\text { second) }\end{array}$ \\
\hline C1 & 04110000 & Orchard Creek at Munith & 49.0 & $1944-56$ & 27.6 \\
C2 & 04111379 & Red Cedar River near Williamston & 163 & $1986-88$ & 95.4 \\
C3 & 04111500 & Deer Creek near Dansville & 16.3 & $1954-91$ & 6.8 \\
C4 & 04112000 & Sloan Creek near Williamston & 9.34 & $1954-91$ & 3.0 \\
C5 & 04112500 & Red Cedar River at East Lansing & 355 & $1931-91$ & 146 \\
C6 & 04112850 & Sycamore Creek near Holt & 80.6 & $1976-80$ & 34.3 \\
C7 & 04113000 & Grand River at Lansing & 1,230 & $1935-92$ & 619 \\
C8 & 04113097 & Carrier Creek near Lansing & 12.1 & $1975-81$ & 3.5 \\
C9 & 04114000 & Grand River at Portland & 1,385 & $1953-81$ & 699 \\
C10 & 04114500 & Looking Glass River near Eagle & 281 & $1945-91$ & 153 \\
\hline
\end{tabular}

Table 2. Partial-record streamflow-gaging stations in the Tri-County region, Michigan, used in the analysis of ground-water flow

\begin{tabular}{llllccc}
\hline $\begin{array}{c}\text { Map } \\
\text { index }\end{array}$ & $\begin{array}{c}\text { UsGS gaging } \\
\text { station No. }\end{array}$ & \multicolumn{1}{c}{ Stream } & \multicolumn{1}{c}{$\begin{array}{c}\text { Tributary } \\
\text { to: }\end{array}$} & $\begin{array}{c}\text { Drainage } \\
\text { area } \\
\text { (square } \\
\text { miles) }\end{array}$ & $\begin{array}{c}\text { Number of } \\
\text { measure- } \\
\text { ments }\end{array}$ & $\begin{array}{c}\text { Base flow } \\
\text { estimate } \\
\text { (cubic feet } \\
\text { per second) }\end{array}$ \\
\hline M1 & 04110650 & Huntoon Creek & Grand River & 11.2 & 10 & 6.3 \\
M2 & 04110663 & Unnamed tributary & Perry Creek & .95 & 13 & 1.6 \\
M3 & 04111033 & Grand River & Lake Michigan & 722 & 19 & 909 \\
M4 & 04111200 & Red Cedar River & Grand River & 71.2 & 11 & 18.2 \\
M5 & 04111410 & Doan Creek & Red Cedar River & 54.8 & 10 & 12.0 \\
M6 & 04112670 & Willow Creek & Sycamore Creek & 1.61 & 12 & 2.5 \\
M7 & 04112700 & Sycamore Creek & Red Cedar River & 39.5 & 10 & 13.8 \\
M8 & 04112800 & Mud Creek & Sycamore Creek & 30.8 & 12 & 9.9 \\
M9 & 04112900 & Sycamore Creek & Red Cedar River & 96.2 & 11 & 49.8 \\
M10 & 04113050 & Grand River & Lake Michigan & 1,248 & 33 & 639 \\
M11 & 04113975 & Frayer Creek & Grand River & 11.3 & 11 & 4.3 \\
M12 & 04114400 & Looking Glass River & Grand River & 234 & 22 & 93.3 \\
M13 & 04114570 & Bear Creek & Maple River & 29.5 & 29 & 11.8 \\
M14 & 04114580 & Maple River & Grand River & 91.8 & 12 & 22.5 \\
M15 & 04114589 & Little Maple River & Maple River & 7.90 & 21 & 3.3 \\
M16 & 04114590 & Little Maple River & Maple River & 11.4 & 29 & 4.4 \\
M17 & 04114592 & Little Maple River & Maple River & 15.4 & 11 & 7.1 \\
M18 & 04114594 & Maple River & Grand River & 153 & 45 & 82.4 \\
M19 & 04114595 & Baker Creek & Maple River & 9.10 & 31 & 2.1 \\
M20 & 04115700 & Stony Creek & Maple River & 57.9 & 10 & 14.0 \\
M21 & 04115760 & Muskrat Creek & Stony Creek & 37.2 & 11 & 7.9 \\
M22 & 04115830 & Libhart Creek & Grand River & 33.0 & 23 & 15.6 \\
M23 & 04115850 & Little Libhart Creek & Libhart Creek & 14.1 & 22 & 4.8 \\
M24 & 04116700 & Thornapple River & Grand River & 71.5 & 11 & 32.4 \\
M25 & 04116800 & Thornapple River & Grand River & 160 & 10 & 51.0 \\
\hline
\end{tabular}


In unconfined aquifers, estimates of water-table altitude can be obtained by measuring stages in hydraulically connected lakes or perennial streams. In the TriCounty region, data for 2,932 wells contained in the State Ground-Water Data Base (SGDB) system (S. Businski, Michigan Department of Environmental
Quality, written commun., 1993), data for 805 watersurface altitudes of lakes and contour crossings of perennial stream channels posted on 7.5-minute topographic maps, and 130 measurements from observation wells were used to make initial estimates of ground-water levels (figs. 5 and 6).

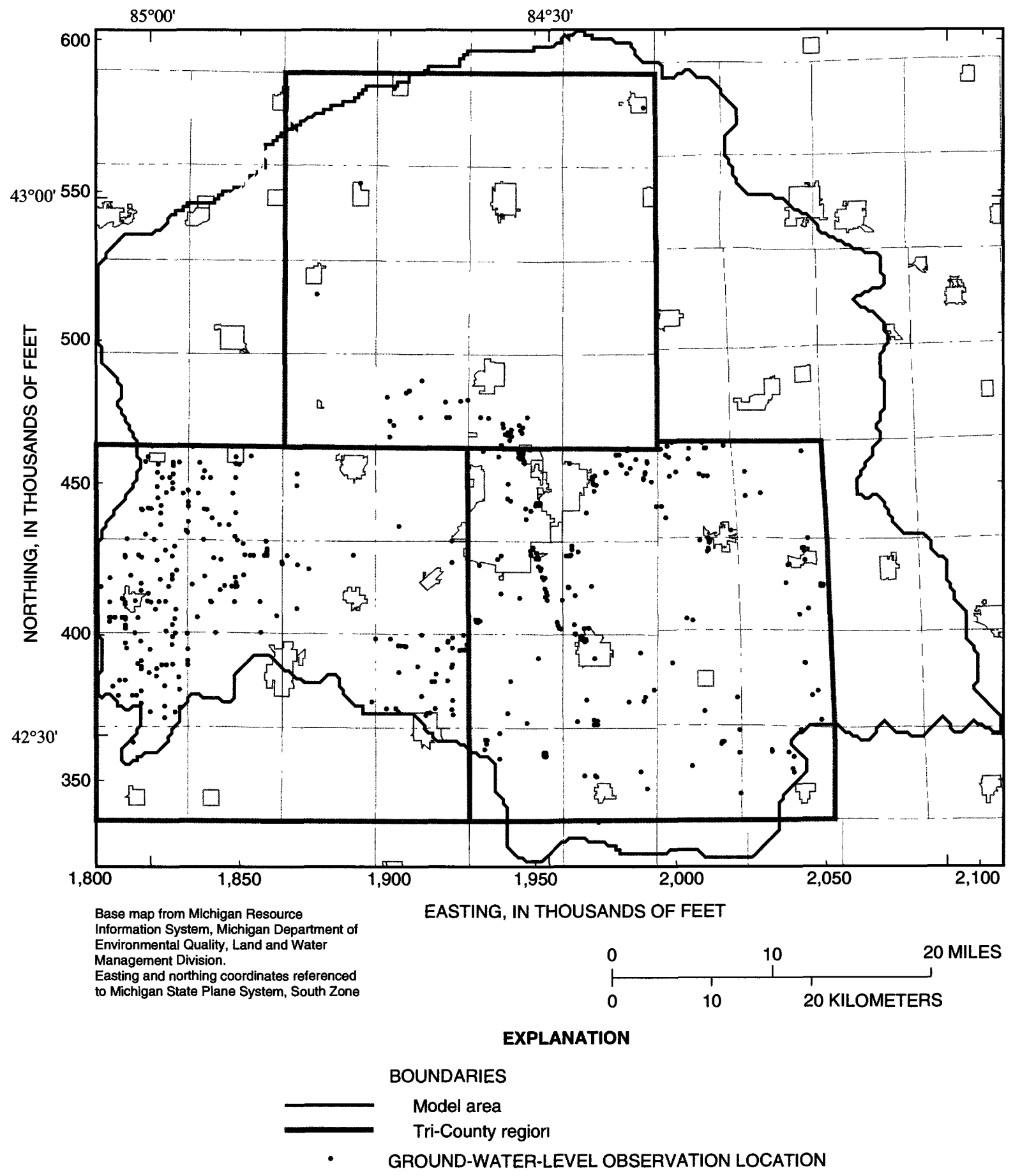

Figure 5. Wells screened in the glacial deposits in the Tri-County region, Michigan, in which water levels were measured only once. 


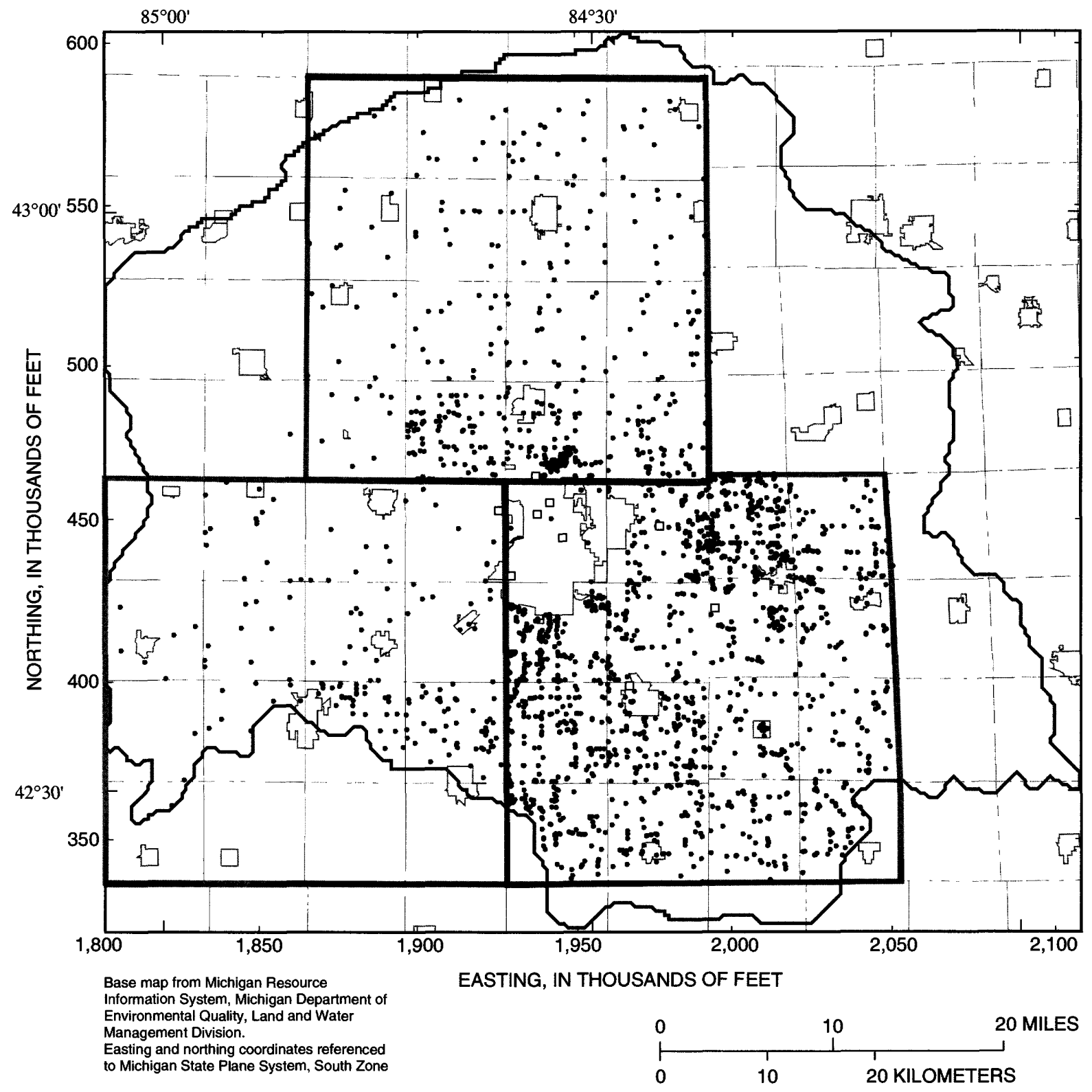

EXPLANATION

BOUNDARIES

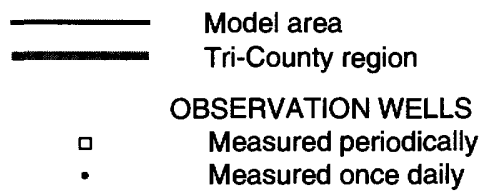

Figure 6. Wells completed in the Saginaw aquifer in the Tri-County region, Michigan, in which water levels were measured one or more times. 
A contour map of water-table altitudes or hydraulic heads provides an indication of flow in an aquifer. Ground water flows from areas of higher to lower water-table altitudes or hydraulic heads. If water flows in an aquifer with equal ease in any horizontal direction, the hydraulic conductivity of the aquifer is considered to be horizontally isotropic. In a horizontally isotropic aquifer, ground-water flow is perpendicular to contour lines.

\section{History of Water-Resources Development}

Historically, ground water has been the principal source of water supply for the Tri-County region. The City of Lansing, Mich., obtained water from wells screened in aquifers in the glacial deposits from 1885 through 1915; wells drilled into the Saginaw aquifer were added in 1895 . The village of Webberville, Mich., switched from aquifers in the glacial deposits to the Saginaw aquifer in 1956. Other Michigan municipalities, including Eaton Rapids, Mason, and Williamston, use combinations of wells completed in aquifers in the glacial deposits and the Saginaw aquifer. Baltusis and others (1992) summarize sources and annual withdrawals of ground water. Changes in ground-water withdrawals have closely matched changes in population in Lansing (fig. 7). Ground-water withdrawals increased steadily between 1910 and 1960; however, withdrawals since 1970 have been more nearly constant.

In the Tri-County Region, data for 1992 show that most public-supply withdrawals occur from the Saginaw aquifer ( 89.4 percent) or the aquifers in the glacial deposits ( 9.7 percent). The remaining publicsupply withdrawals ( 0.9 percent) are from the Marshall aquifer in southwestern Eaton County (fig. 8). Of the total ground-water withdrawals in the TriCounty region, municipalities withdrew 97.2 percent (Luukkonen, 1995). Most water is publicly supplied in Eaton and Ingham Counties, but most water is selfsupplied in Clinton County.

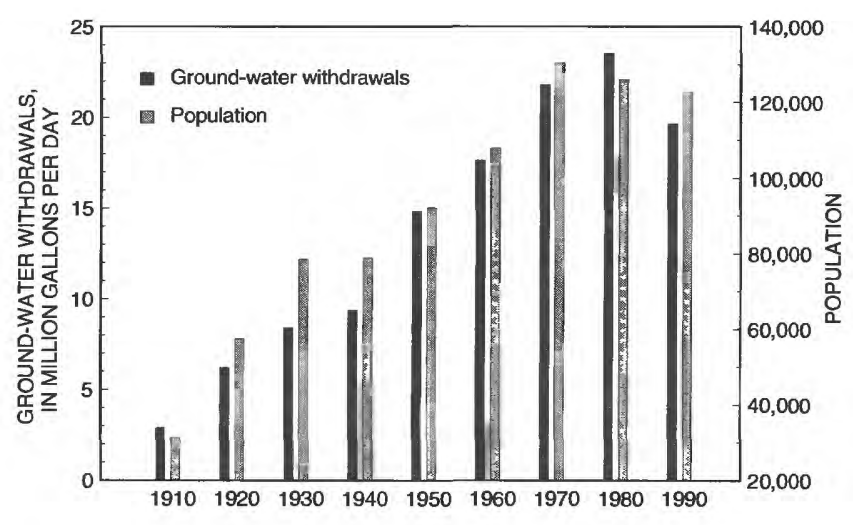

Figure 7. Ground-water withdrawals and population, Lansing, Michigan, 1910-90.

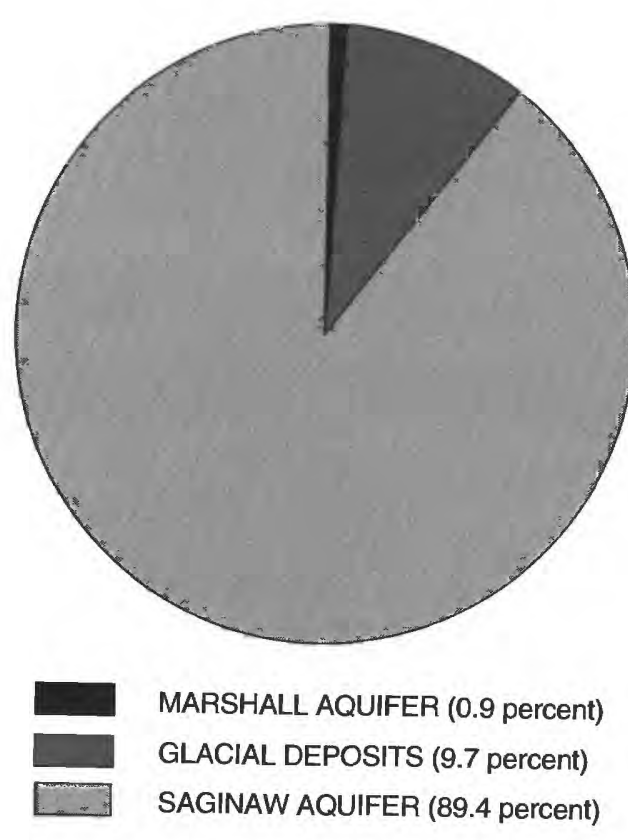

Figure 8. Sources of water for public supply, Tri-County region, Michigan.

\section{SIMULATION OF GROUND-WATER FLOW}

\section{Conceptual Model}

The conceptual model of ground-water flow synthesizes available geologic and hydrologic data into a form that is amenable to analysis. Principal elements in the conceptual model are ground-water flow directions and flow-system boundaries. 
Ground-water flow in the glacial deposits is generally from south to north (fig. 9), away from topographic divides and towards surface-water bodies. Thus, drainage divides are assumed to be groundwater flow divides for water in the glacial deposits.

Most ground-water flow in the Saginaw aquifer is from south to north, although a small amount is toward local pumping centers (fig. 10). Flow across the east and west model area, where the sandstone of the Saginaw Formation is very thin or absent, is minimal. The Saginaw aquifer is recharged principally by leakage from the glacial deposits. Generally, ground water flows toward Maple River, which forms the north hydrologic boundary of the model area; locally, some ground water flows toward the south hydrologic boundary. Ground water also discharges locally from bedrock to the glacial deposits beneath valleys of major streams. The bottom of the Saginaw aquifer is assumed to be impermeable.

Another assumption in the conceptual model is steady-state ground-water flow; that is, no net gain or loss in the ground-water-flow system. In this conceptual model, recharge from precipitation or flow into the model area across model boundaries equals discharge to streams and wells and flow out of the model area across model boundaries. Implicit in the steadystate assumption is that measured heads and flows represent long-term average conditions, because true steady-state conditions do not occur. However, the relative constancy of ground-water withdrawals since 1970 (fig. 7) and the constancy of average precipitation and evaporation rates makes the steady-state assumption tenable.

\section{Numerical Model}

Ground-water flow was simulated by use of MODFLOW (McDonald and Harbaugh, 1988), a numerical model that simulates flow in three dimensions by solving a finite-difference approximation of the partial differential equations describing groundwater flow through porous media. The numerical model was used to simulate steady-state ground-water flow. Consequently, no ground-water storage terms or temporal discretization were required for solution.

\section{Model Grid and Layers}

The model area is a rectangular area of $3,131 \mathrm{mi}^{2}$ centered on the Tri-County region (fig. 11). The model area is 53.75 mi long (north-south) and 58.25 mi wide (east-west). This area is horizontally discretized into a grid of equally spaced cells in 215 rows and 233 columns. Each cell is 1,320 by $1,320 \mathrm{ft}$. The model area is vertically discretized into two layers: the upper layer represents the aquifers in the glacial deposits, and the lower layer represents the Saginaw aquifer. Each grid cell represents the average aquifer properties in the volume of aquifer represented by the cell; thus, any variations in properties that are within the volume represented by the grid cell cannot be represented by the model.

The model grid is oriented to the southern zone of the Michigan State Plane Coordinate System as displayed on USGS 7.5-minute topographic quadrangle maps. The minimum easting coordinate of the model area is $1,801,500 \mathrm{ft}$; the maximum easting is $2,109,060 \mathrm{ft}$; the minimum northing is $320,880 \mathrm{ft}$; and the maximum northing is $604,680 \mathrm{ft}$.

\section{Boundary Conditions}

In this report, boundary conditions refer to hydraulic conditions at selected cells where flow can enter and exit the model. Boundaries are classified as either external or internal. External boundaries form a perimeter around and define the active model area. About 67 percent of the cells in the Tri-County regional ground-water flow model area are active. Boundary conditions consistent with the conceptual model are specified for each layer of the model.

Boundary conditions for the upper layer are represented by external and internal boundaries. External boundary conditions for the upper layer are constant head and no-flow (fig. 11). No-flow boundaries are located at drainage divides and ground-water divides; constant head cells are located along Grand River on the south and Maple and Grand Rivers on the north. The upper boundary of the upper layer is the water table which is represented as a specified flow equal to spatially distributed recharge rate. Internal boundaries for the upper layer are head-dependent flow or river cells. 


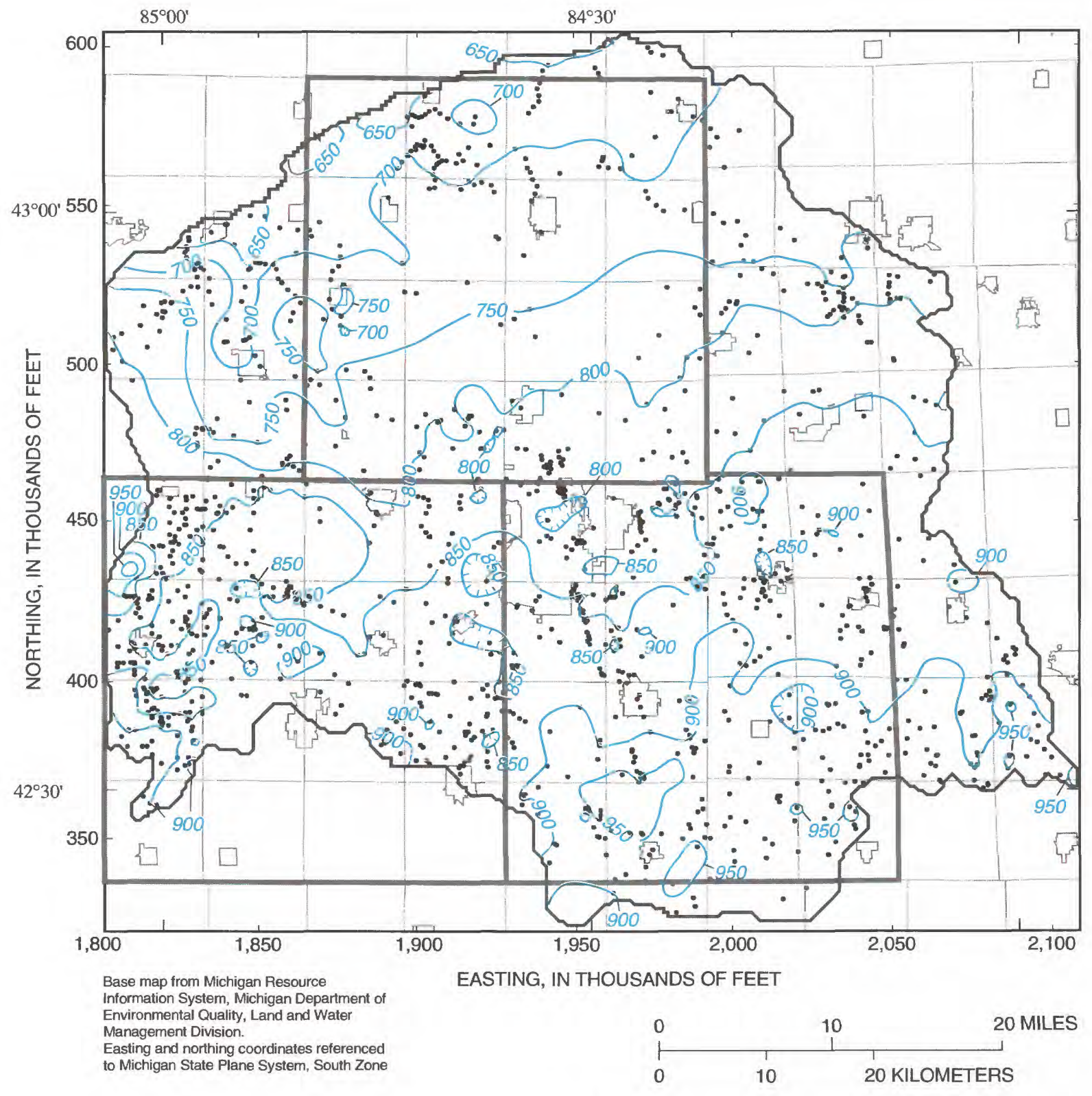

EXPLANATION

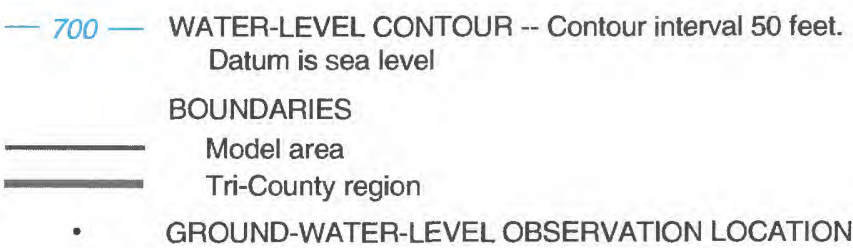

Figure 9. Ground-water levels in the glacial deposits in the model area, Tri-County region, Michigan. 


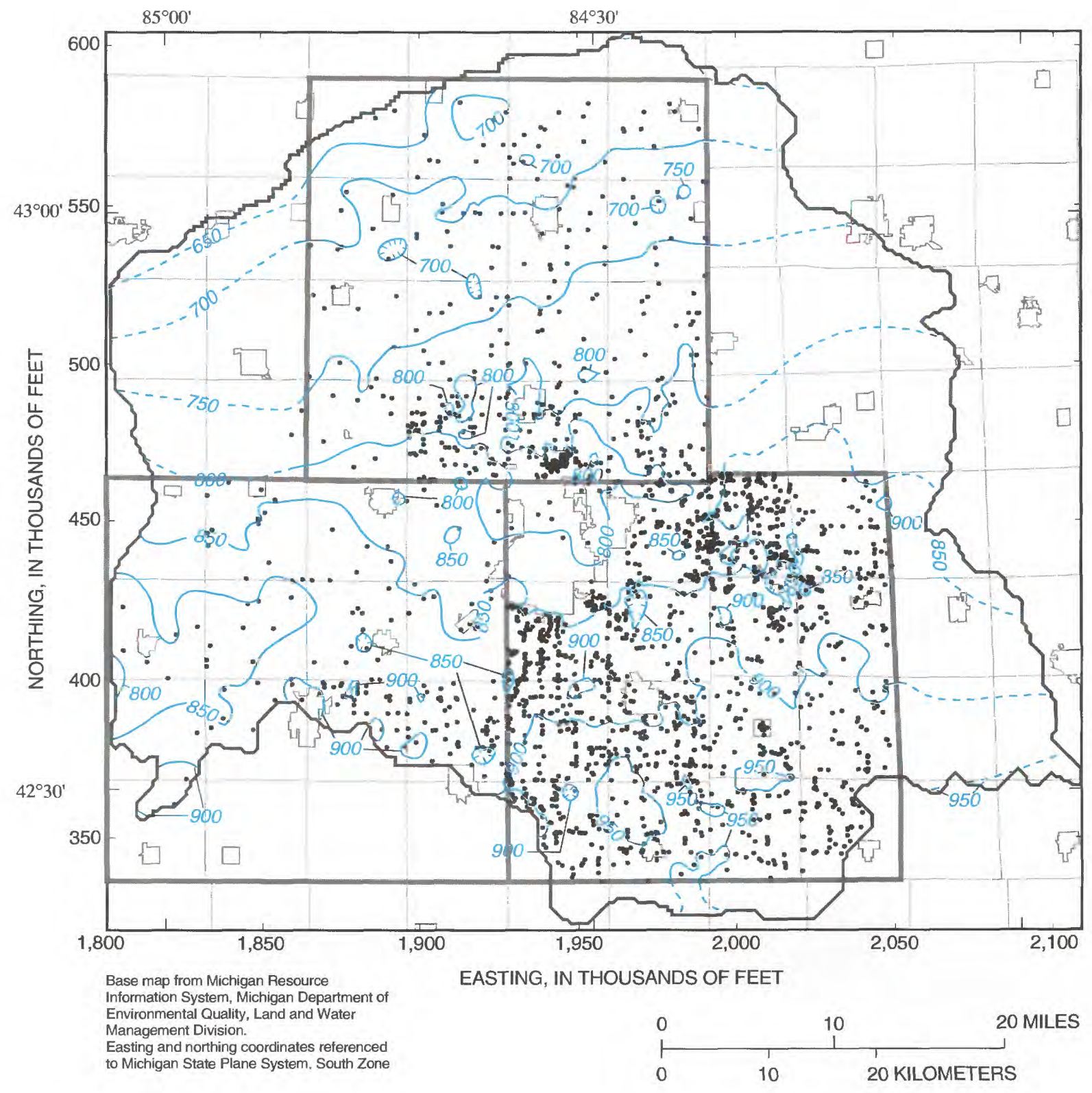

EXPLANATION

- 700 - - WATER-LEVEL CONTOUR -- Dashed where approximately located.

Contour interval 50 feet. Datum is sea level

BOUNDARIES

Model area

Tri-County region

GROUND-WATER-LEVEL OBSERVATION LOCATION

Figure 10. Ground-water levels in the Saginaw aquifer in the model area, Tri-County region, Michigan. 


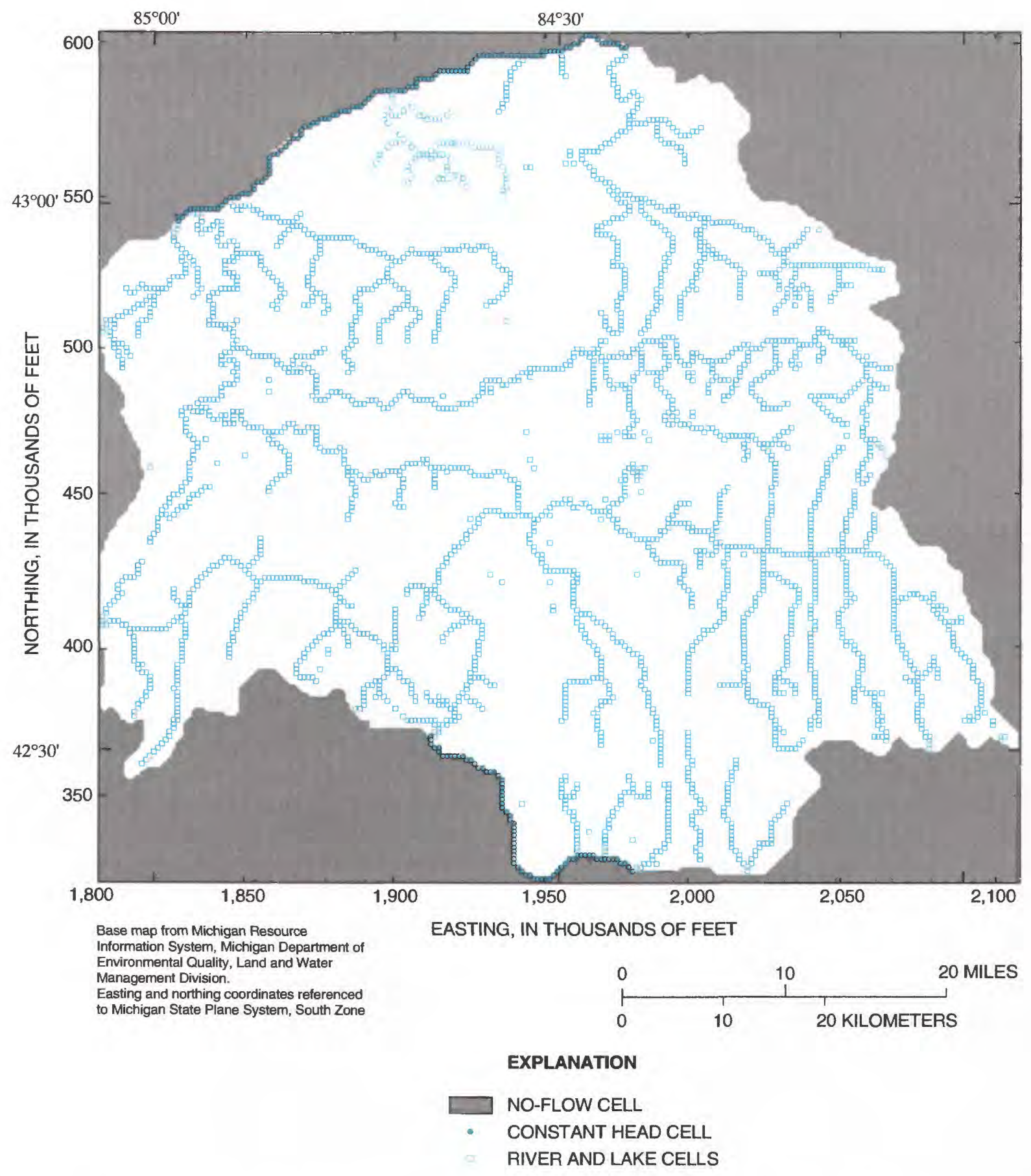

Figure 11. Grid and upper-layer boundary conditions for the model area, Tri-County region, Michigan 
Boundary head values were based on contour data shown on USGS 7.5-minute topographic quadrangle maps; linear interpolation was used, where necessary, to estimate head values at cells between contours. Flow into or out of river cells is governed by stream stage, simulated head in the stream cell, and conductance of the streambed material (McDonald and Harbaugh, 1988). The lower boundary of the upper layer is the bedrock surface.

External boundary conditions for the lower layer are constant head and no-flow. No-flow boundaries are outside the outermost active cells in the upper layer, except where constant-head cells are located along Grand River on the south. For the most part, the no-flow cells are located where little sandstone is present in the Saginaw Formation. In the north, the noflow cells require water to discharge to Grand and Maple Rivers, consistent with the conceptual model. River cells are located in the lower layer where the Saginaw Formation crops out near Grand Ledge. The lower boundary of the lower layer is the bottom of the Saginaw aquifer and is a no-flow boundary. Finally, ground-water withdrawals from public-supply wells are represented by sink terms in the upper and lower layers.

\section{Spatial Distribution of Input Properties}

Spatial distribution of input properties includes geologic and hydrologic characteristics that are needed for ground-water flow simulation. Input properties were discretized for the model configuration from field measurements and other sources of information. In the model, input properties include (1) the geometry of model layers, (2) ground-water recharge rates, and (3) initial estimates of the spatial variations in aquifer hydraulic properties, including transmissivity in the Saginaw aquifer, horizontal hydraulic conductivity in the glacial deposits, vertical hydraulic conductivity between the Saginaw aquifer and the glacial deposits, and streambed conductance. A discussion of methods used in determining the input properties follows.

\section{Layer Geometry}

Layer geometry is the spatial variation in the altitudes of the top and bottom of the upper and lower layers. Land-surface altitude is used as the top of the glacial deposits. Land-surface altitudes in the TriCounty region (fig. 12) were estimated on the basis of point-altitude data displayed on USGS 7.5-minute maps in the study area. The point-altitude data include vertical control stations, generally shown as altitudes rounded to the nearest foot at road intersections, and contour lines crossing the centerline of perennial streams. Land surface was approximated by triangulation and linear interpolation (Keckler, 1994, p. 5-15) of data from 8,620 vertical control stations and 1,046 contour crossings of streams.

Land-surface altitudes were then used in combination with well-log data to estimate the altitude of the water table. After a well is drilled, the depth from the land surface to the water is recorded in the well log. For each well in which the depth to water was measured, the altitude of the water table could be calculated by subtracting the depth to water from the interpolated land-surface altitude. These water-level data, along with data from contour crossings of streams, define the altitude of the water table. For model simulations, the top of the upper layer is the altitude of the water table, which defines the top of the unconfined aquifer. The bottom of the upper layer (fig. 13), which also is the top of the lower layer, is the upper surface of the Pennsylvanian rocks (Westjohn and Weaver, 1996).

The bottom of lower layer was determined on the basis of the surface configuration of the ParmaBayport aquifer (Westjohn and Weaver, 1996). The Saginaw confining unit is thought to separate the Pennsylvanian rocks from the Parma-Bayport aquifer. For the purposes of this study, the thickness of the Saginaw confining unit was assumed to average $50 \mathrm{ft}$ in the Tri-County region. Thus, the altitude of the bottom of the lower layer was calculated as the surface of the Parma-Bayport aquifer plus $50 \mathrm{ft}$ (fig. 14). 


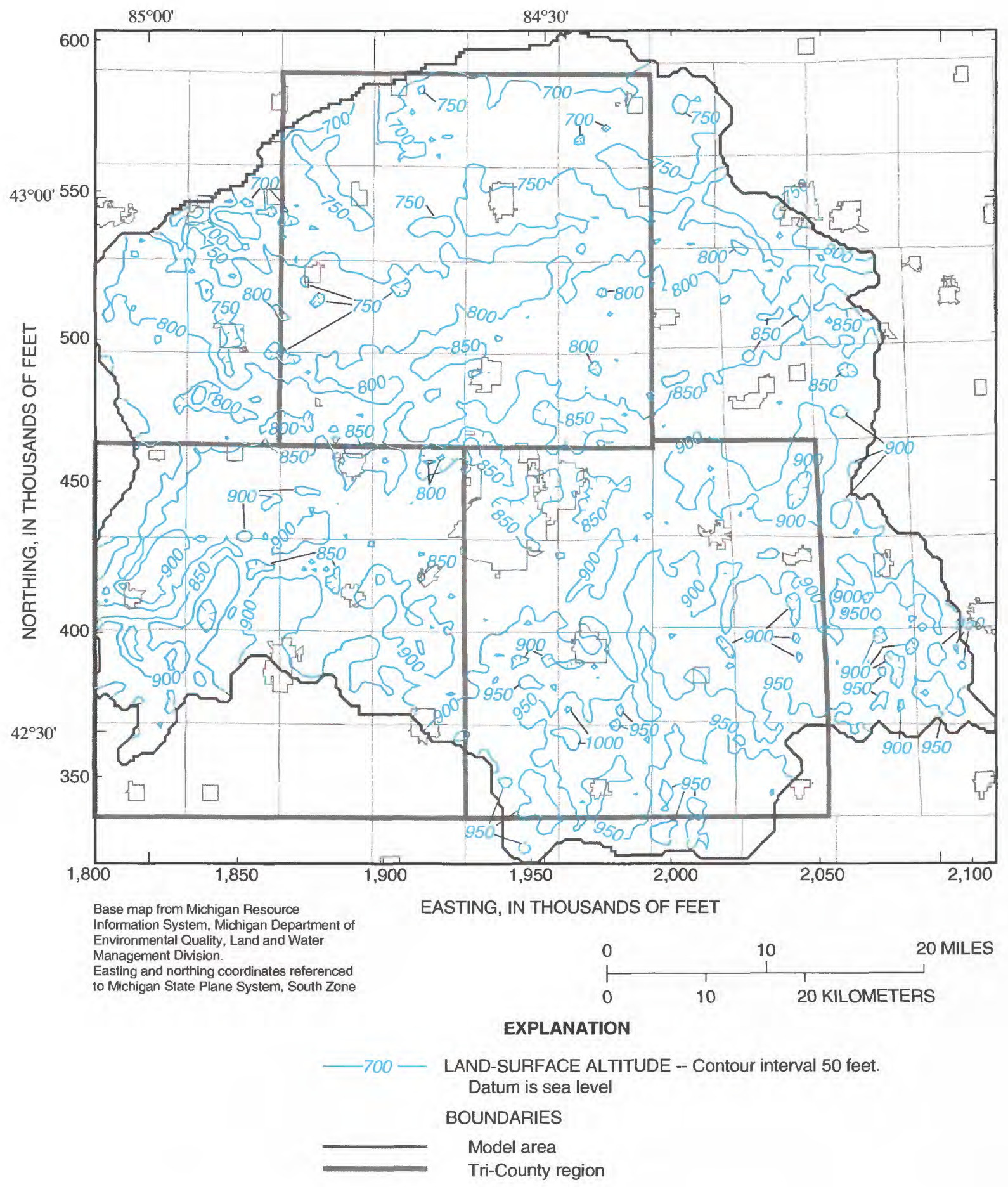

Figure 12. Estimated land-surface altitude in the model area, Tri-County region, Michigan. 


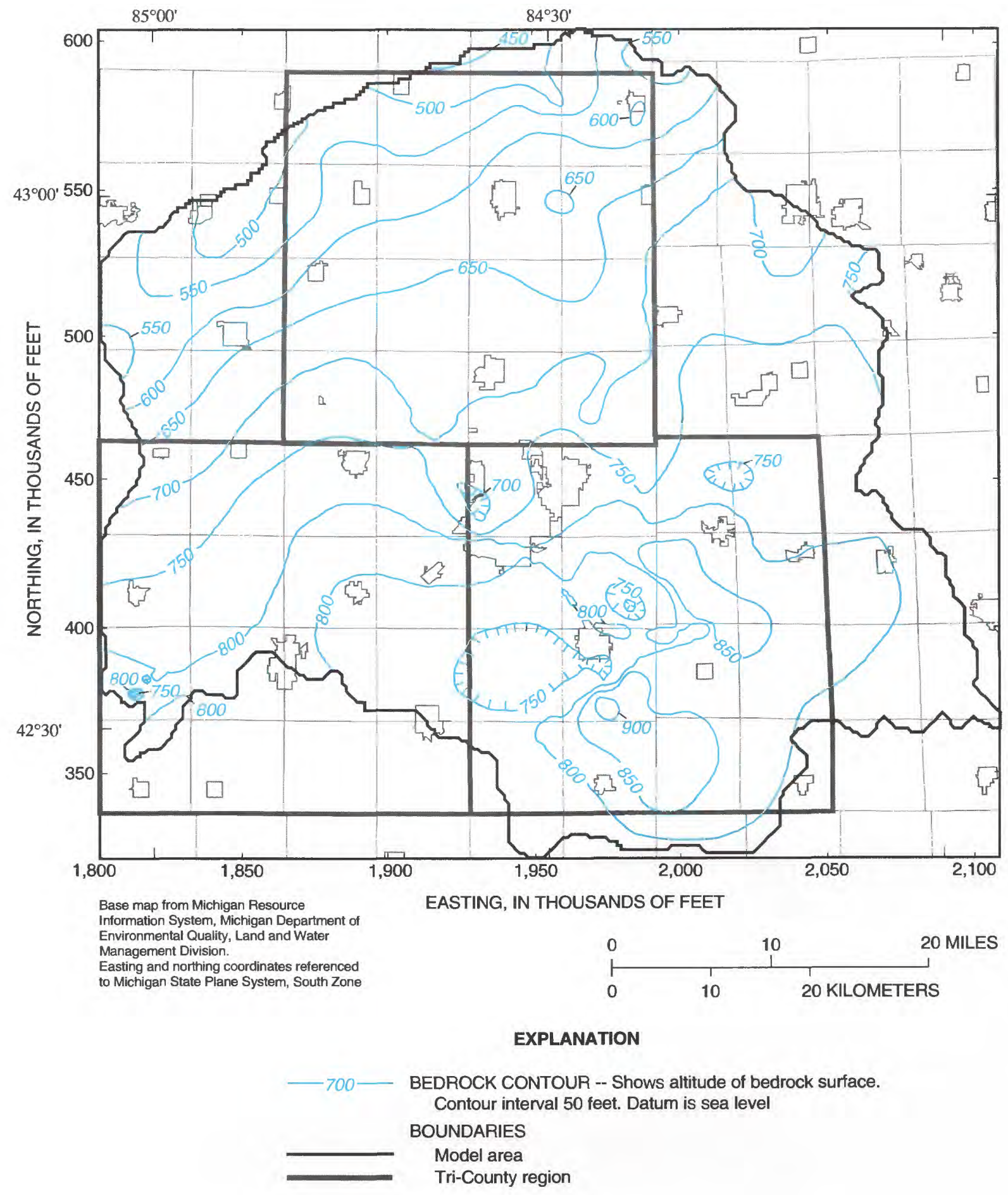

Figure 13. Altitude of the bottom of the upper model layer, Tri-County region, Michigan. 


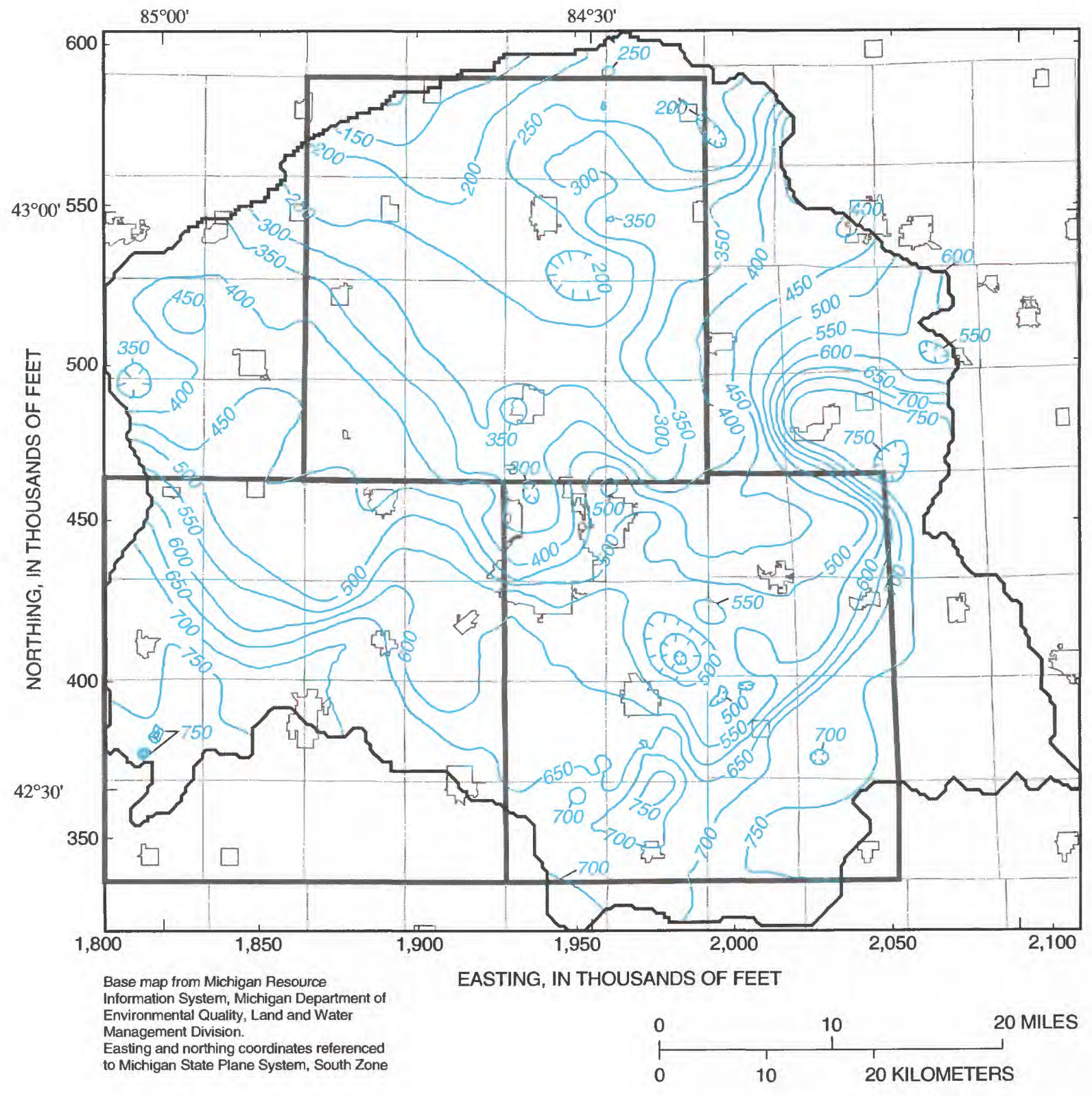

EXPLANATION

- $700-$ BEDROCK CONTOUR - Shows altitude of bedrock surface.

Contour interval 50 feet. Datum is sea level

BOUNDARIES

Model area

Tri-County region

Figure 14. Altitude of the bottom of the lower model layer, Tri-County region, Michigan 


\section{Ground-Water Recharge Rates}

The spatial variation of average ground-water recharge rates for 1951-80 (fig. 15) was determined from an analysis relating base flow characteristics of streams to land use and basin characteristics in the Lower Peninsula of Michigan (Holtschlag, 1994). On the basis of this study, the minimum average annual recharge in the Tri-County region is $4.4 \mathrm{in} / \mathrm{yr}$, and the maximum is $16.5 \mathrm{in} / \mathrm{yr}$; the spatial average groundwater recharge rate is $6.7 \mathrm{in} / \mathrm{yr}$.

\section{Hydraulic Properties of Aquifers}

Values assigned as hydraulic properties of aquifers control simulated ground-water flow through and between model layers. For this study, hydraulic properties of aquifers were determined as the product of a matrix (with dimensions equal to the model grid), which contains initial estimates of hydraulic properties, and a constant, which was determined by model calibration. The physical evidence and methodology used to develop the matrices of initial estimates of hydraulic properties are described in the following paragraphs.

\section{Transmissivity of the Saginaw Aquifer}

The horizontal flow of water in the Saginaw aquifer was assumed to be proportional to the composite sandstone thickness in the Pennsylvanian rocks. Water is assumed to move slower through the shales and other tight materials than through the sandstone. The sandstone, whose composite thickness ranges from 0 to $300 \mathrm{ft}$, is thickest in the northern part of the TriCounty region. The hydraulic conductivity of sandstone was initially estimated to be $7.5 \mathrm{ft} / \mathrm{d}$ on the basis of local aquifer-test results (B. Fisher, Michigan Department of Public Health, written commun., 1994). The transmissivity of the Saginaw aquifer equals the estimated hydraulic conductivity of sandstone times the composite sandstone thickness. Initial estimates of transmissivity range from 50 to $2,300 \mathrm{ft}^{2} / \mathrm{d}$. Transmissivity is highest in the central part of the model area and lowest along the west, south, and east boundaries of the model area.

\section{Horizontal Hydraulic Conductivity of the Glacial Deposits}

The horizontal flow of water in the glacial deposits is controlled by hydraulic conductivity, which varies with the texture of the unconsolidated materials.
Because of the local variability and non-homogeneity of glacial deposits, a statistical technique was used to provide initial estimates of the spatial variation in hydraulic conductivity on the basis of well-log data and hydraulic conductivities commonly associated with lithologic materials.

Well drillers routinely record the thickness and texture of materials through which a well is being drilled. In the Tri-County Region, driller's logs of 10,000 wells have been computerized by various governmental agencies for improved access and analysis. Of these well logs, 8,058 were produced by experienced drillers each of whom has drilled 100 or more wells in the Tri-County region.

During the process of computerizing the well logs, strata codes are assigned by the Michigan Geological Survey to similar lithologies. For this analysis, hydraulic conductivities were associated with each strata code (table 3 ) by taking the midpoint of the hydraulic-conductivity range for similar materials, as reported by Freeze and Cherry $(1979$, p. 29). Effective hydraulic conductivities were computed for each well by use of procedures described by McDonald and Harbaugh (1988, p. 5-2).

Initial estimates of the spatial variation of hydraulic conductivity in the glacial deposits also were based on an analysis of hydraulic conductivities computed for individual wells. To identify possible differences in interpretation of similar geologic materials among drillers, the distribution of effective hydraulic conductivities was compared among drillers who had drilled more than 100 wells each in the Tri-County region. For each driller, the distribution of hydraulic conductivities tended to be skewed; that is, a small proportion of values were much greater than the average. Comparison of distributions among drillers was aided by the use of a square-root transformation, which tended to make the distributions more nearly symmetrical. Comparison indicates that distributions of computed hydraulic conductivities were similar among most drillers (fig. 16). Data for driller $C$ and driller $N$ tended to produce somewhat higher average values; these deviations may reflect either differences in interpretation of similar geologic materials or local differences in geologic properties where the wells were drilled. 


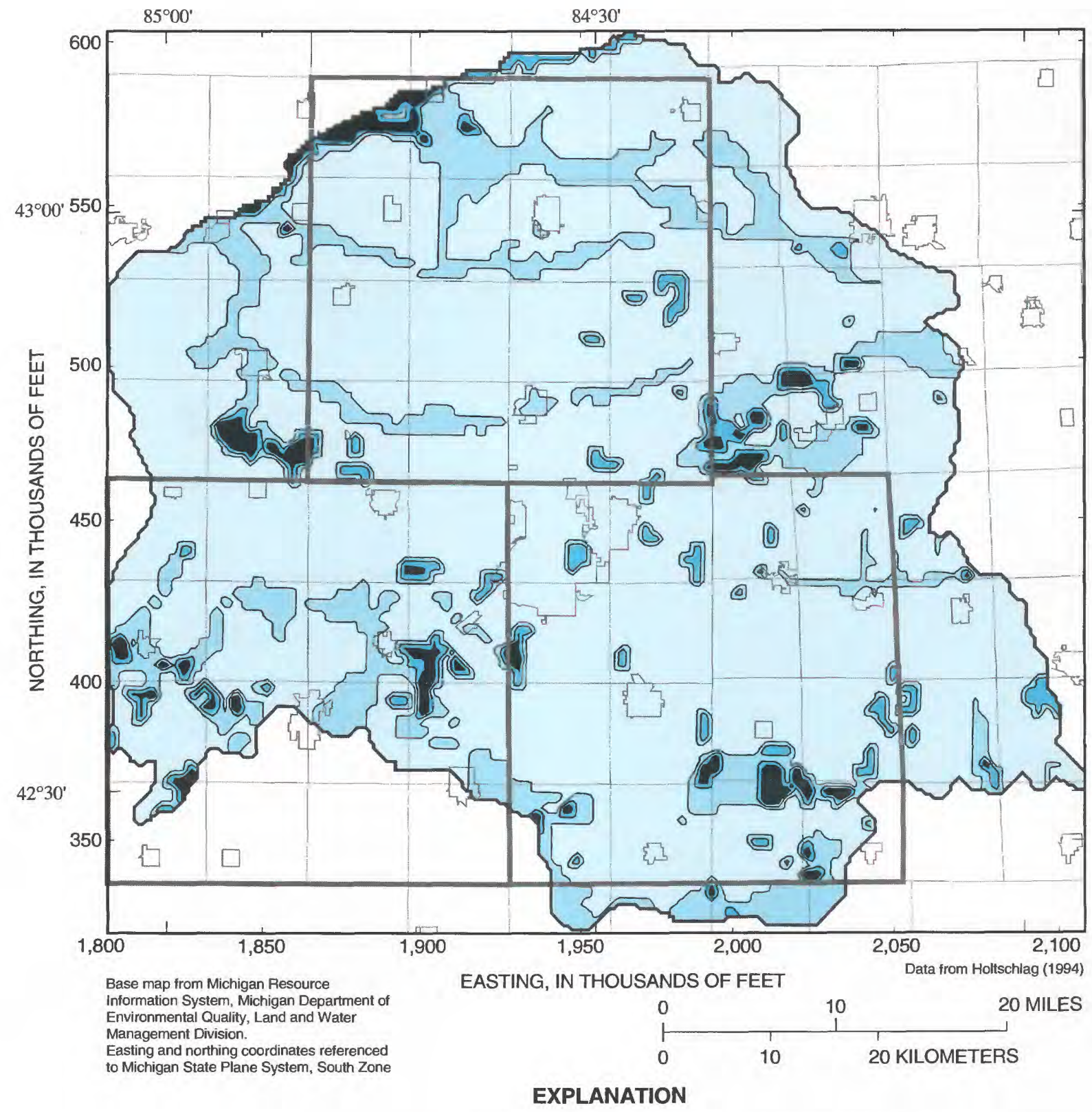

ANNUAL RECHARGE RATE, IN INCHES PER YEAR

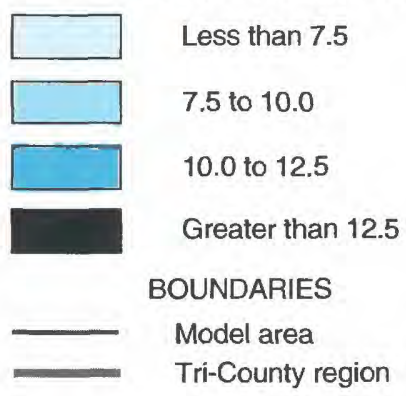

Figure 15. Spatial variation of average ground-water recharge in the model area, Tri-County region, Michigan. 
Table 3. Estimated hydraulic conductivities associated with strata codes in the statewide ground-water data base of Michigan

\begin{tabular}{|c|c|c|}
\hline $\begin{array}{c}\text { Hydraulic } \\
\text { conductivity } \\
\text { (feet per day) }\end{array}$ & $\begin{array}{l}\text { Strata } \\
\text { code }\end{array}$ & Lithologic description \\
\hline 0.000001 & 11 & Hard clay \\
\hline 0.00001 & $\begin{array}{l}10 \\
12 \\
14\end{array}$ & $\begin{array}{l}\text { Clay/clay fill } \\
\text { Soft clay } \\
\text { Fine sandy clay }\end{array}$ \\
\hline 0.0001 & $\begin{array}{l}13 \\
16\end{array}$ & $\begin{array}{l}\text { Sandy clay/sandy, silty clay } \\
\text { Clay and sand/silty, clay }\end{array}$ \\
\hline 0.001 & $\begin{array}{l}15 \\
44 \\
45\end{array}$ & $\begin{array}{l}\text { Silt/sandy silt } \\
\text { Muck } \\
\text { Marl }\end{array}$ \\
\hline 0.01 & $\begin{array}{l}17 \\
18 \\
19 \\
40 \\
49\end{array}$ & $\begin{array}{l}\text { Clay and gravel } \\
\text { Hardpan } \\
\text { Till } \\
\text { Top soil } \\
\text { Drift }\end{array}$ \\
\hline 0.1 & $\begin{array}{l}41 \\
42 \\
43\end{array}$ & $\begin{array}{l}\text { Organic soil } \\
\text { Black dirt } \\
\text { Fill }\end{array}$ \\
\hline 10 & $\begin{array}{l}27 \\
28 \\
31 \\
46\end{array}$ & $\begin{array}{l}\text { Sand and clay } \\
\text { Sand with clay } \\
\text { Gravel and clay } \\
\text { Peat }\end{array}$ \\
\hline 30 & $\begin{array}{l}20 \\
21 \\
22 \\
23 \\
26 \\
29\end{array}$ & $\begin{array}{l}\text { Sand/sandy fill } \\
\text { Fine sand/silty sand } \\
\text { Medium sand } \\
\text { Coarse sand } \\
\text { Sand with gravel } \\
\text { Water sand }\end{array}$ \\
\hline 100 & $\begin{array}{l}25 \\
30 \\
32 \\
33 \\
34 \\
35 \\
36 \\
37\end{array}$ & $\begin{array}{l}\text { Sand and gravel } \\
\text { Gravel } \\
\text { Gravel and sand } \\
\text { Fine gravel } \\
\text { Medium gravel } \\
\text { Coarse gravel } \\
\text { Water gravel } \\
\text { Gravel and cobbles }\end{array}$ \\
\hline 1,000 & $\begin{array}{l}38 \\
39\end{array}$ & $\begin{array}{l}\text { Gravel and boulders } \\
\text { Boulders }\end{array}$ \\
\hline
\end{tabular}

The spatial correlation characteristics of the computed effective hydraulic conductivities also were investigated. Spatial correlation quantifies how the similarity of hydraulic conductivities at individual wells changes as a function of separation distance. Spatial correlation is commonly interpreted on the basis of a variogram analysis. In this study, all empirical variograms were modeled as the sum of a white noise (nugget) component and a monotonically increasing function of separation distance described as a Gaussian component (Marsily, 1986, p. 303). The general variogram model can be written

$\gamma(h)=\beta_{0}(1-\delta(h))+\beta_{1}\left(1-\exp \left(-\left(\frac{h}{\beta_{2}}\right)^{2}\right)\right)$

where

$\gamma(h)$ is the value of the variogram at separation distance $h$,

$\beta_{0}$ is a parameter associated with the nugget component,

$\delta(h)$ is the Kronecker delta function, which takes on a nonzero value of 1 only at $h=0$, and

$\beta_{1}$ and $\beta_{2}$ are parameters associated with the Gaussian component.

Effective horizontal hydraulic conductivity values were transformed by the square-root function to facilitate identification of the spatial correlation structure. Records from 7 of the 18 drillers revealed a spatial correlation structure; these records, which included data for 4,947 wells, were used in the subsequent kriging analysis. Variogram models were estimated by adjusting model parameters (table 4) so that model estimates matched the empirical variogram. The interpretation of the variogram for driller $I 2$ is shown in figure 17.

Ordinary kriging (Cressie, 1991, p. 360) was used to map a smooth estimate of the spatial variation of hydraulic conductivity. Block-average estimates and associated variances were computed for each cell in the model grid on the basis of each driller's set of wells and corresponding variogram model. 


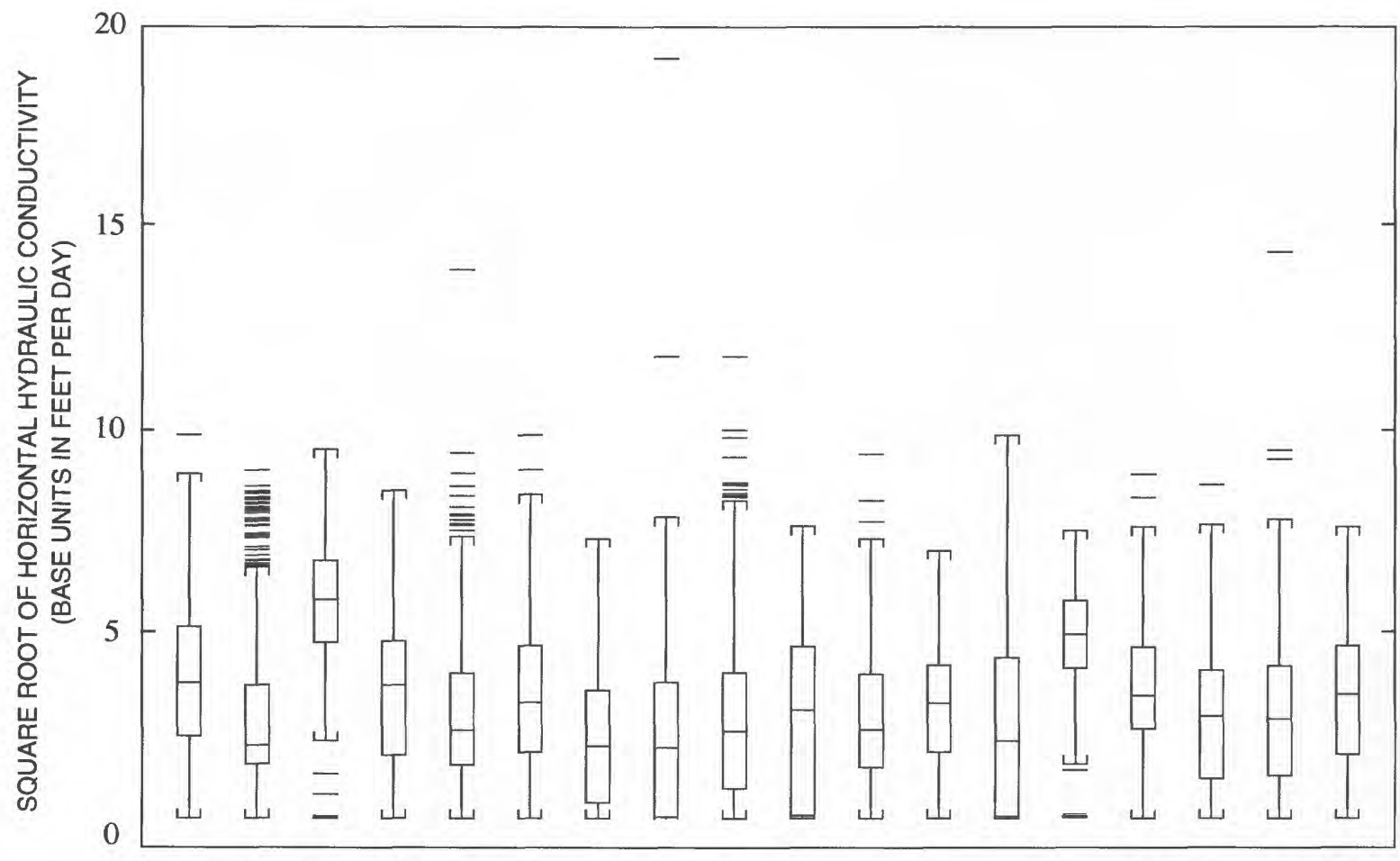

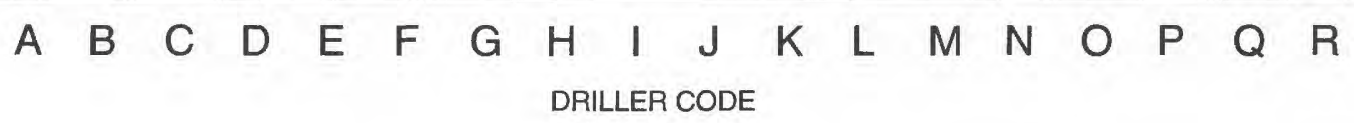
EXPLANATION

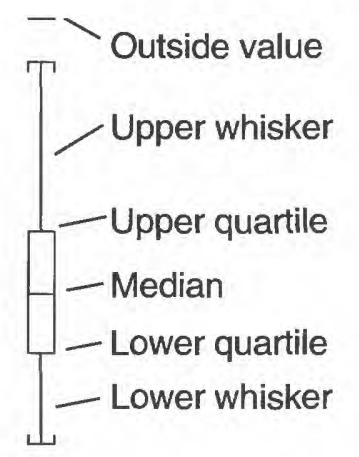

Whiskers show the range of values that fall within 1.5 times the difference between the upper quartile and the lower quartile

Figure 16. Distribution of effective horizontal hydraulic conductivities in the glacial deposits in the model area, Tri-County region, Michigan. 
Table 4. Parameters for models of sample variogram of hydraulic conductivity, Tri-County region, Michigan

[--, drillers' records were not used to define the spatial correlation structure]

\begin{tabular}{|c|c|c|c|c|c|c|c|}
\hline \multirow{2}{*}{$\begin{array}{l}\text { Driller } \\
\text { code }\end{array}$} & \multirow{2}{*}{$\begin{array}{l}\text { Number of } \\
\text { wells }\end{array}$} & \multicolumn{3}{|c|}{$\begin{array}{l}\text { Parameters for variogram model of horizontal } \\
\text { hydraulic conductivity }\end{array}$} & \multicolumn{3}{|c|}{$\begin{array}{l}\text { Parameters for variogram model of vertica } \\
\text { hydraulic conductivity }\end{array}$} \\
\hline & & $\beta_{0}$ & $\beta_{1}$ & $\beta_{2}$ & $\beta_{0}$ & $\beta_{1}$ & $\beta_{2}$ \\
\hline A & 462 & -- & -- & -- & - & -- & -- \\
\hline B & 960 & 2.40 & 1.70 & 1,500 & 8.00 & 10.0 & 1,750 \\
\hline C & 175 & -- & -- & -. & -. & -- & -- \\
\hline $\mathrm{D} 1^{1}$ & 600 & 3.90 & 2.35 & 1,300 & 9.25 & 1.50 & 1,350 \\
\hline $\mathrm{D} 2^{1}$ & 473 & 4.45 & 1.45 & 1,800 & 3.75 & 1.50 & 3,000 \\
\hline $\mathrm{E}$ & 659 & 5.50 & 1.75 & 3,000 & 18.0 & 5.00 & 2,000 \\
\hline F & 196 & 2.00 & 3.00 & 2,000 & 10.0 & 18.0 & 1,200 \\
\hline G & 179 & 6.00 & 1.40 & 3,000 & 7.00 & 2.00 & 2,500 \\
\hline H & 275 & -- & -- & -- & -- & -- & -- \\
\hline$\left[1^{1}\right.$ & 900 & 6.00 & 2.80 & 2,500 & 10.5 & 4.75 & 3,000 \\
\hline $12^{1}$ & 768 & 3.00 & 5.00 & 900 & 5.50 & 5.50 & 900 \\
\hline $\mathbf{J}$ & 212 & 4.25 & 3.25 & 1,500 & 8.00 & 4.00 & 1,500 \\
\hline K & 243 & -- & -- & -- & -- & - & -- \\
\hline L & 349 & -- & -- & -- & -- & -- & -- \\
\hline $\mathbf{M}$ & 653 & - & -- & - & -- & -- & -- \\
\hline $\mathrm{N}$ & 158 & -- & - & -- & -- & -- & -- \\
\hline o & 129 & -- & - & -- & -- & -- & -- \\
\hline$P$ & 113 & - & -- & -- & -- & -- & -- \\
\hline $\mathrm{Q}$ & 270 & -- & -- & -- & -- & -- & - \\
\hline R & 284 & -- & - & -- & -- & -- & - \\
\hline
\end{tabular}

${ }^{1}$ Data from individual well drillers having more than 1.000 wells were split into two groups due to memory limitations of the software.

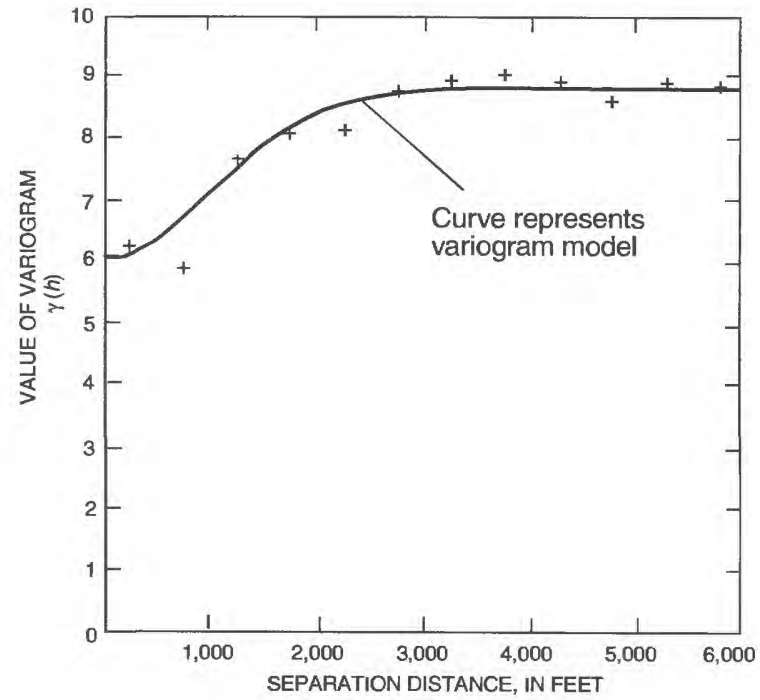

Figure 17. Variogram of effective horizontal hydraulic conductivity in the glacial deposits, computed on the basis of wells logged by driller $I 2$ in the model area, Tri-County region, Michigan.
A minimum variance estimate of hydraulic conductivity for each model cell was computed by weighting estimates (determined on the basis of individual driller records) in inverse proportion to their corresponding variances. The initial estimate of the spatial variation of effective horizontal hydraulic conductivities was determined by squaring the weighted averages. Initial estimates of horizontal hydraulic conductivity range from 7.06 to $27.5 \mathrm{ft} / \mathrm{d}$. Horizontal hydraulic conductivity is highest in the west-central part of the model area and lowest in the north and south parts of the model area.

\section{Vertical Hydraulic Conductivity}

Vertical hydraulic conductivity between the Saginaw aquifer and the glacial deposits was assumed to be controlled by the effective vertical hydraulic conductivity in the glacial deposits. Effective vertical hydraulic conductivities (McDonald and Harbaugh, 1988, p. 5-2), computed from logs of drillers who have drilled more than 100 wells in the Tri-County region, were based on values for hydraulic conductivity associated with specific strata codes 
(table 3). The distributions of effective vertical hydraulic conductivities were more skewed than the distributions of effective horizontal hydraulic conductivities. A natural logarithm transformation was used to reduce the distributional asymmetry and to facilitate comparison among drillers. After transformation, the distributions of effective vertical hydraulic conductivity for several drillers showed a tri-modal characteristic, with modes at about $-11,-4$, and 3 on the natural logarithm scale (fig. 18). This characteristic exaggerates the apparent variability in the interquartile ranges (the difference between the logarithms of hydraulic conductivities at the upper and lower quartiles) among drillers.

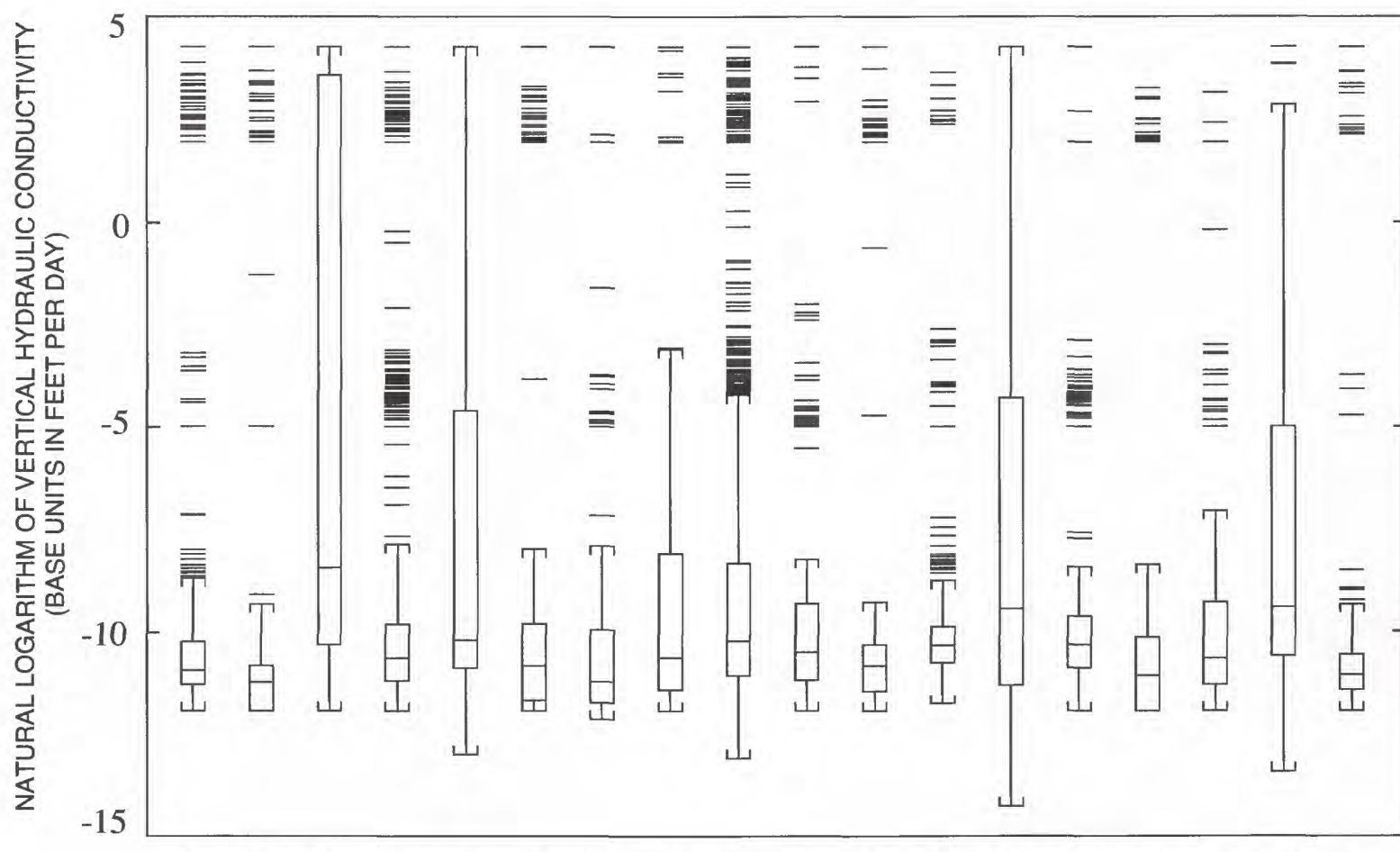

$\begin{array}{lllllllllllllllllll}A & B & C & D & E & F & G & H & \text { I } & J & K & L & M & N & O & P & Q & R\end{array}$ DRILLER CODE

\section{EXPLANATION}

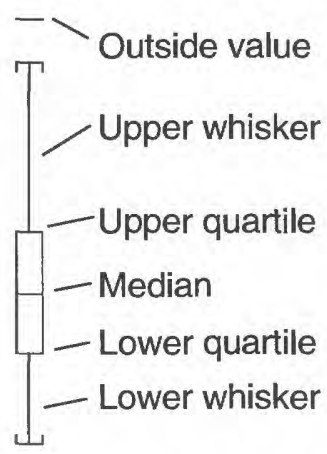

Whiskers show the range of values that fall within 1.5 times the difference between the upper quartile and the lower quartile

Figure 18. Distribution of effective vertical hydraulic conductivities in the glacial deposits in the model area, Tri-County region, Michigan. 
The spatial correlation structure of effective vertical hydraulic conductivity was interpreted on the basis of variogram analysis. The empirical variograms were modeled (fig. 19) as the sum of a nugget component and a Gaussian component (table 4), similar to the analysis of effective horizontal hydraulic conductivity. Ordinary block kriging was used to develop an estimate of the spatial variation of effective vertical hydraulic conductivities and an associated variance from records of individual drillers. A weighted average of these estimates was computed, and then the weighted average was exponentiated to provide the initial estimate of the spatial variation of effective vertical hydraulic conductivities. Initial estimates of vertical hydraulic conductivity range from $1.4 \times 10^{-5}$ to $1.2 \times 10^{-3} \mathrm{ft} / \mathrm{d}$. Vertical hydraulic conductivity is highest in the southern part of the model area and lowest in the northern part of the model area. In MODFLOW, vertical leakance values, computed by dividing vertical hydraulic conductivity by the local thickness of the glacial deposits, were used for simulation.

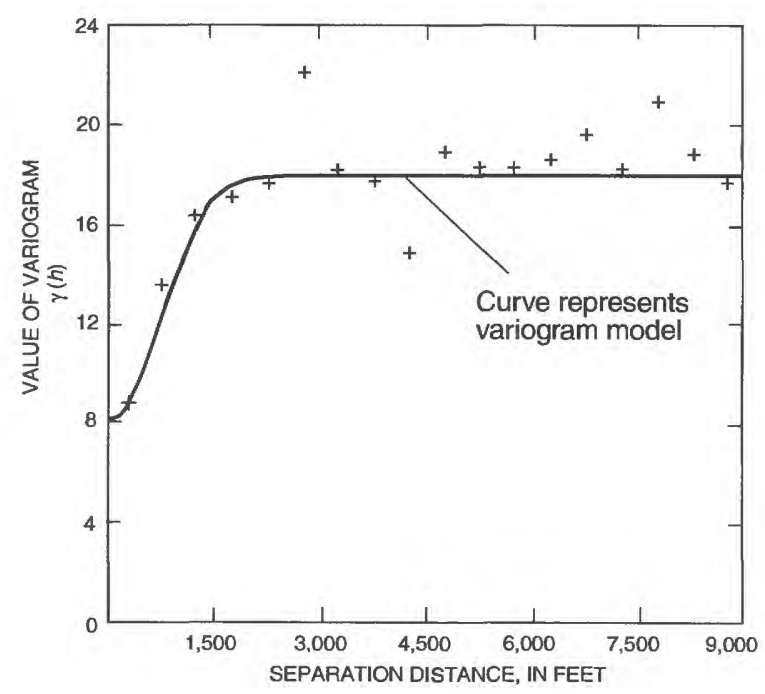

Figure 19. Variogram of effective vertical hydraulic conductivity in the glacial deposits, computed on the basis of wells logged by driller $B$ in the model area, Tri-County region, Michigan.

\section{Streambed Conductance}

The vertical flow of ground water from an aquifer to a stream is controlled by streambed conductance. In MODFLOW, streambed conductance is computed as the product of the hydraulic conductivity of the streambed materials, stream length, and stream width, divided by the streambed thickness (McDonald and Harbaugh, 1988, p. 6-5). To simplify estimation of the response from these interrelated properties, the hydraulic conductivity of the streambed materials, stream length, and streambed thickness were assumed to be constant for all streams in the model area. Stream widths were divided into four size classes corresponding to average widths of $10,50,150$, and $300 \mathrm{ft}$ (fig. 20). Hydraulic conductivity of the streambed materials was initially estimated to be $0.076 \mathrm{ft} / \mathrm{d}$. Stream length is specified as equal to the length of the cell $(1,320 \mathrm{ft})$, and streambed thickness is arbitrarily assigned as $1 \mathrm{ft}$.

\section{Model Calibration}

Model calibration is a process of adjusting the number and value of selected model parameters to reduce model error; that is, the difference between simulated and measured hydraulic heads and flows. Model error results from the simplification of the flow system in the conceptual model and its finite-difference approximation. Model error can usually be reduced by increasing the number of model parameters. However, increasing the number of parameters will also increase the estimation error resulting from uncertainty as to the true parameter values (Yeh, 1986). Thus, an appropriate balance between model error and estimation error is needed.

\section{Parameter-Estimation Techniques}

In this study, the ground-water flow model was calibrated by use of a nonlinear regression method developed by Cooley and Naff (1990) and modified by Hill (1992) for use with MODFLOW. The nonlinear regression method, MODFLOWP, is an automated method to calculate optimal parameter values. 


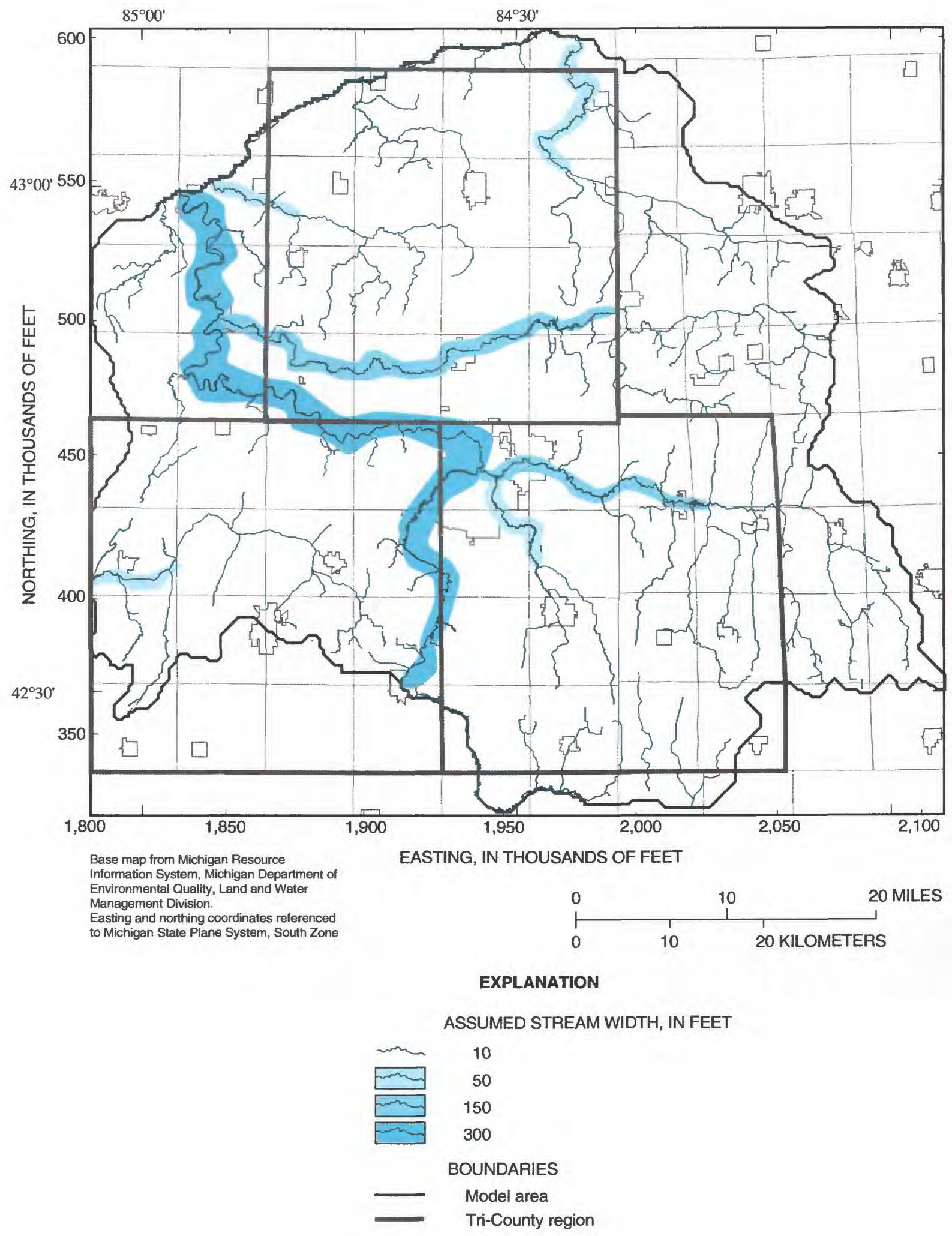

Figure 20. Distribution of stream size classes in the model area, Tri-County region, Michigan. 
In MODFLOWP, optimal parameter values are those that minimize the sum of squared errors (SSE):

$$
S S E=\sum_{i=1}^{n}\left[\sqrt{w_{i}} \cdot e_{i}\right]^{2},
$$

where

$e_{i}$ is the difference between the observed and simulated values of measurement $i$,

$\sqrt{w_{i}}$ is the square root of the weight assigned to the error in the observed value of measurement $i$,

$\sqrt{w_{i}} \cdot e_{i}$ is the weighted residual corresponding to measurement $i$, and

$n$ is the number of measurements.

Because the calculated parameter values are optimal for the given set of assumptions about the aquifer system, the remaining error results from these assumptions being incorrect.

Scaled parameter sensitivities are computed before parameter estimates in MODFLOWP. The set of scaled sensitivities $\left\{\chi_{i}\right\}$ associated with each model parameter is computed as

$$
\left\{\chi_{i}\right\}_{j}=\frac{\partial y_{i}}{\partial b_{j}} \cdot \sqrt{w_{i}} \cdot b_{j},
$$

where

$y_{i}$ for $i=1,2, \ldots n$ are measurements of hydraulic head or flow, and

$b_{j}$ for $j=1,2, \ldots p$ are estimated model parameters.

Scaled sensitivities are a measure of how much simulated heads or flows vary with changes in model parameters. Parameters with low sensitivities have little effect on simulated results and cannot be estimated accurately by regression or by trial and error. If sensitivities are very low for a parameter, then the regression will not converge to a solution. An iterative analysis of parameter sensitivities and alternative model forms resulted in the selection of a fourparameter model. The selected model form contains parameters that scale initial estimates of the spatial variations in aquifer hydraulic properties to match head and flow measurements. The four model parameters are multiplicative constants for matrices containing initial estimates of transmissivity in the Saginaw aquifer, horizontal hydraulic conductivity in the glacial deposits, vertical hydraulic conductivity between the Saginaw aquifer and the glacial deposits, and streambed conductance.

\section{Initial Parameter Estimates}

Once the form of the regression model was identified, optimal parameters were estimated in nonlinear regression by varying initial parameter estimates to minimize the weighted sum of squares for error. In this analysis, parameters were varied from a starting value of 1.0 until mass-balance errors computed by MODFLOW were eliminated, computed and measured heads and flows were reasonably consistent, and total flow from constant-head nodes was within a plausible range.

\section{Measurements and Weighting}

The error criterion used in this analysis was the weighted sum of squared residuals (eq. 2). The measurements were weighted to account for differences in measurement accuracy and differences in units of measurement. In general, more weight was assigned to measurements whose measurement variances were low. A somewhat arbitrary weighting factor was applied so that data from not only head measurements but also flow measurements affected parameter estimates. The weighting strategy used in this model calibration is described below.

Head data used in the calibration of the groundwater flow model were obtained from three sources. First, the SGDB contained 2,932 head measurements that were compiled from drillers' logs. Of these, 572 were in the upper layer and 2,360 were in the lower layer. Measurements in the upper layer were not restricted to a particular time period. However, measurements in the lower layer were restricted to the period 1984-92 because of local trends in the historical ground-water-head data associated with changes in pumping conditions. Second, 805 ground-water levels in the upper layer were inferred from water-surface altitudes posted for lakes and contour crossings of perennial streams on 7.5-minute topographic maps. And third, 130 head measurements were obtained from nine monitoring wells in the lower layer.

Errors in head measurements were assumed to be normally distributed. Measurements from the SGDB and altitudes of surface-water bodies were estimated to be accurate within $\pm 7 \mathrm{ft}, 90$ percent of the time. This level of precision corresponds to a standard deviation of $4.26 \mathrm{ft}$. This uncertainty is associated with estimating a datum from a topographic map, measuring depth to water in a recently developed well, and fluctuations in levels of surface-water bodies. Measurements at monitoring wells were estimated to be accurate within $\pm 2 \mathrm{ft} 90$ percent of the time, a level of precision that corresponds to a standard deviation of 
$1.22 \mathrm{ft}$. This greater precision was considered appropriate because datums from monitoring wells are commonly established by field survey and measurements are obtained by specially trained and equipped observers.

The average head in 1,164 model cells in the upper layer and 1,627 model cells in the lower layer was computed on the basis of the measured head data. The minimum variance estimate of the average head in a model cell was computed by weighting individual head measurements within a cell in inverse proportion to their respective variances (standard deviations, from the previous paragraph, squared). Corresponding estimates of the variances of average heads within cells also were computed.

Streamflow data used to calibrate the groundwater flow model originated from daily mean streamflow data from continuous-record gaging stations and streamflow-measurement data from partial-record gaging stations. Daily mean streamflows from 10 gaging stations in the Tri-County region were disaggregated into surface-runoff and base-flow components (table 1 ) by use of a streamflow partitioning technique (Rutledge, 1993). The average base-flow component was assumed to represent average ground-water discharge. Although no precise measure of uncertainty for estimates of base flow is available, the assumption for this analysis was that the standard error of the base-flow estimate was 10 percent.

A statistical model was developed between streamflow measurements at 25 partial-record gaging stations and corresponding daily mean streamflow at continuous-record gaging stations (fig. 4). Base flow at the partial-record stations (table 2) was estimated from this statistical relation and the base flow determined at the continuous-record gaging station (table 1). The uncertainty of base flow at the partial-record stations was based on the standard error of the statistical relation.

The incremental ground-water discharge between gaging stations was computed as the difference between base flows at each station. The variance of the increments was computed as the sum of the variances of the base-flow estimates at the upstream- and downstream-reach limits. Ground-water discharge upstream from the most upstream gaging station on a stream was taken as the base flow at that station.

Initial estimates of the standard errors of the average heads in model cells were adjusted during preliminary MODFLOWP runs to increase the relative significance of streamflow data, which were measured in cubic feet per second, and to correspond more closely with the error characteristics computed by the parameter-estimation model. Final estimates of the standard error of average heads within cells were computed by multiplying the initial estimate of standard deviation by 2 and adding $5 \mathrm{ft}$.

\section{Optimal Parameter Estimates}

The optimal values for the four parameters estimated by use of nonlinear regression are given in table 5. The optimization reduced the weighted sum of squared residuals by 97 percent, from an initial value of $1.50 \times 10^{5}$ to a minimum value of $4.05 \times 10^{3}$. The estimated standard deviations at the optimal values indicated that all the parameters are likely to be significantly different from zero; however, the exact level of significance could not be determined by linear estimation. The model was determined to be nonlinear on the basis of modified Beale's measure (Hill, 1994, p. 45), which could not be calculated for the optimal parameter set.

Table 5. Parameter estimates for coefficients multiplying matrices that describe the spatial variation of hydraulic properties, Tri-County region, Michigan

\begin{tabular}{|c|c|c|c|c|c|}
\hline \multirow[b]{2}{*}{ Estimate } & \multirow[b]{2}{*}{ Statistic } & \multicolumn{4}{|c|}{ Parameter } \\
\hline & & $\begin{array}{l}\text { Transmissivity of } \\
\text { the Saginaw aquifer } \\
\text { (feet squared per day) }\end{array}$ & $\begin{array}{l}\text { Hydraulic conductivity } \\
\text { within the glacial } \\
\text { deposits } \\
\text { (feet per day) }\end{array}$ & $\begin{array}{l}\text { Vertical leakance } \\
\text { between the } \\
\text { Saginaw aquifer and } \\
\text { the glacial deposits } \\
\text { (per day) }\end{array}$ & $\begin{array}{c}\text { Streambed } \\
\text { conductance } \\
\text { (feet squared } \\
\text { per day) }\end{array}$ \\
\hline Initial & Estimated value & 1.0 & 1.0 & 1.0 & 1.0 \\
\hline \multirow[t]{3}{*}{ Optimal } & Estimated value & 1.49 & 3.18 & 33.0 & 29.9 \\
\hline & Standard deviation & .126 & 1.46 & 1.50 & 4.49 \\
\hline & Coefficient of variation & .0846 & .457 & .0456 & .150 \\
\hline
\end{tabular}


Correlation between parameters complicates the estimation and interpretation of parameter values; however, in this analysis, the largest correlation between parameters is $\mathbf{0 . 3 5}$, in absolute value. This correlation is far below values that might indicate estimation problems such as collinearity. In addition, the interpretation of the parameters is simplified if the weighted residuals are normally distributed. Although there was some evidence that the weighted residuals were not quite normally distributed, the correlation between the ordered weighted residuals and corresponding standard normal deviates is high $(0.965)$.

The estimated transmissivity in the Saginaw aquifer and the horizontal hydraulic conductivity in the glacial deposits in the model area were computed as the product of the corresponding parameter estimates and the matrices describing the spatial variation. Vertical hydraulic conductivity between the Saginaw aquifer and the glacial deposits was computed as the product of the parameter estimate and the matrix of vertical leakance values multiplied by the local thickness of the glacial deposits. The resulting range in transmissivities is 75.7 to $3,430 \mathrm{ft}^{2} / \mathrm{d}$, in horizontal hydraulic conductivities is 22.3 to $87.5 \mathrm{ft} / \mathrm{d}$, and in vertical hydraulic conductivities is $4.7 \times 10^{-4}$ to $4.0 \times 10^{-2} \mathrm{ft} / \mathrm{d}$ (figs. 21-23). Streambed hydraulic conductivity was estimated to be $2.3 \mathrm{ft} / \mathrm{d}$.

\section{Simulation Results for 1992 Pumping Conditions}

Model simulations were used to compute ground-water heads and flows in the Tri-County region. Comparison of simulated and measured heads is a means of assessing model adequacy for specific applications.

\section{Ground-Water Heads}

Simulated ground-water heads in the upper and lower layers generally are consistent with measured heads. In the upper layer (fig. 24), 50 percent of simulated heads are within $\pm 3.23 \mathrm{ft}$ of measured heads; 90 percent of simulated heads are within $\pm 21.1 \mathrm{ft}$ of measured heads. The standard error of the difference between simulated and measured heads is $12.5 \mathrm{ft}$. In the upper layer, the greatest differences between simulated and measured heads ( -64 to $53 \mathrm{ft}$ ) are in the south and central part of the model area.

In the lower layer (fig. 25), 50 percent of the simulated heads are within $\pm 9.4 \mathrm{ft}$ of measured heads; 90 percent of the simulated heads are within $\pm 25.7 \mathrm{ft}$ of the measured heads. The standard error of the difference between simulated and measured heads is $15.8 \mathrm{ft}$. In the lower layer, the greatest differences between simulated and measured heads $(-49$ to $68 \mathrm{ft})$ are in the central part of the model area. The tendency for simulated heads to overestimate computed heads less than $720 \mathrm{ft}$ above sea level may be associated with local drawdown (where average heads computed from measurements do not adequately represent average cell heads), or it may indicate model limitations. The spatial variation of simulated ground-water heads in the upper and lower layers is shown in figures 26 and 27.

\section{Ground-Water Flow}

To aid in model calibration, simulated discharges of ground water to streams, $\hat{y}_{S}$ (flow to cells in the upper layer that are designated as rivers), were compared to estimates of groundwater flow developed on the basis of streamflow measured at continuous- and partial-record streamflow-gaging stations, $\hat{y}_{M}$ (tables 1 and 2). The results indicate that the estimates are consistent with the line of agreement (fig. 28). In the model area, 50 percent of the simulated streamflows are within $7.1 \mathrm{ft}^{3} / \mathrm{s}$ of the estimates based on measured flow; 90 percent are within $28.8 \mathrm{ft}^{3} / \mathrm{s}$. Four reaches of streams that were indicated as discharging to the aquifer on the basis of streamflow measurements are simulated as receiving water from the aquifer by the model; however, the magnitudes of these flows was small relative to the overall budget of the model. Areas of greatest discrepancy between estimates generally are near model boundaries. 


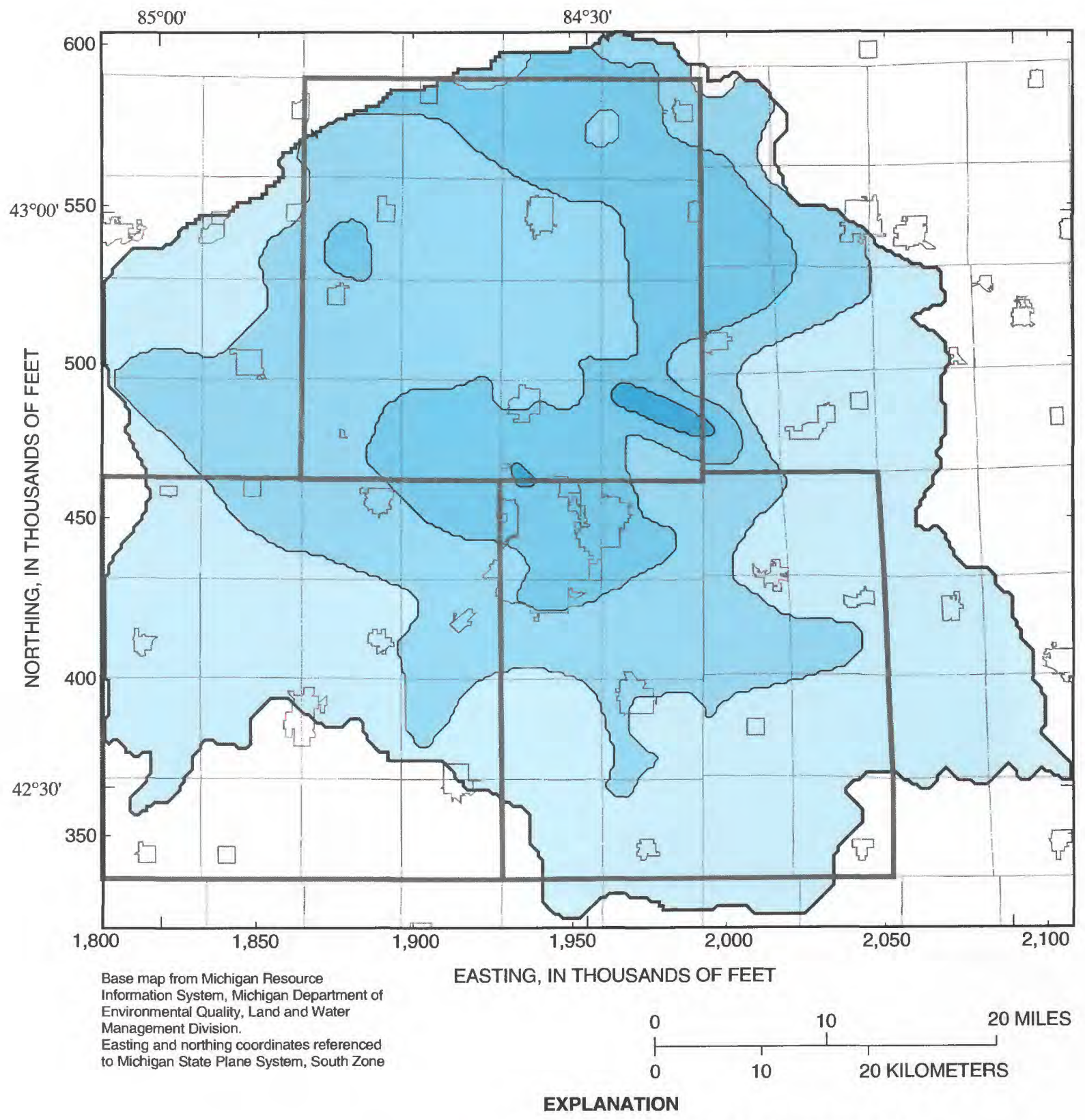

TRANSMISSIVITY, IN FEET SQUARED PER DAY

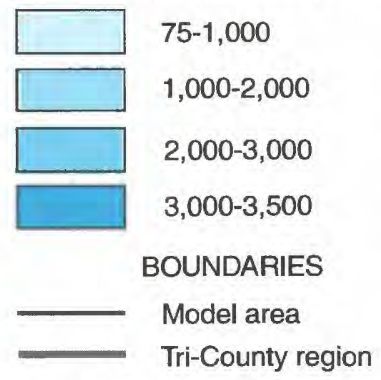

Figure 21. Estimated transmissivity of the Saginaw aquifer in the model area, Tri-County region, Michigan. 


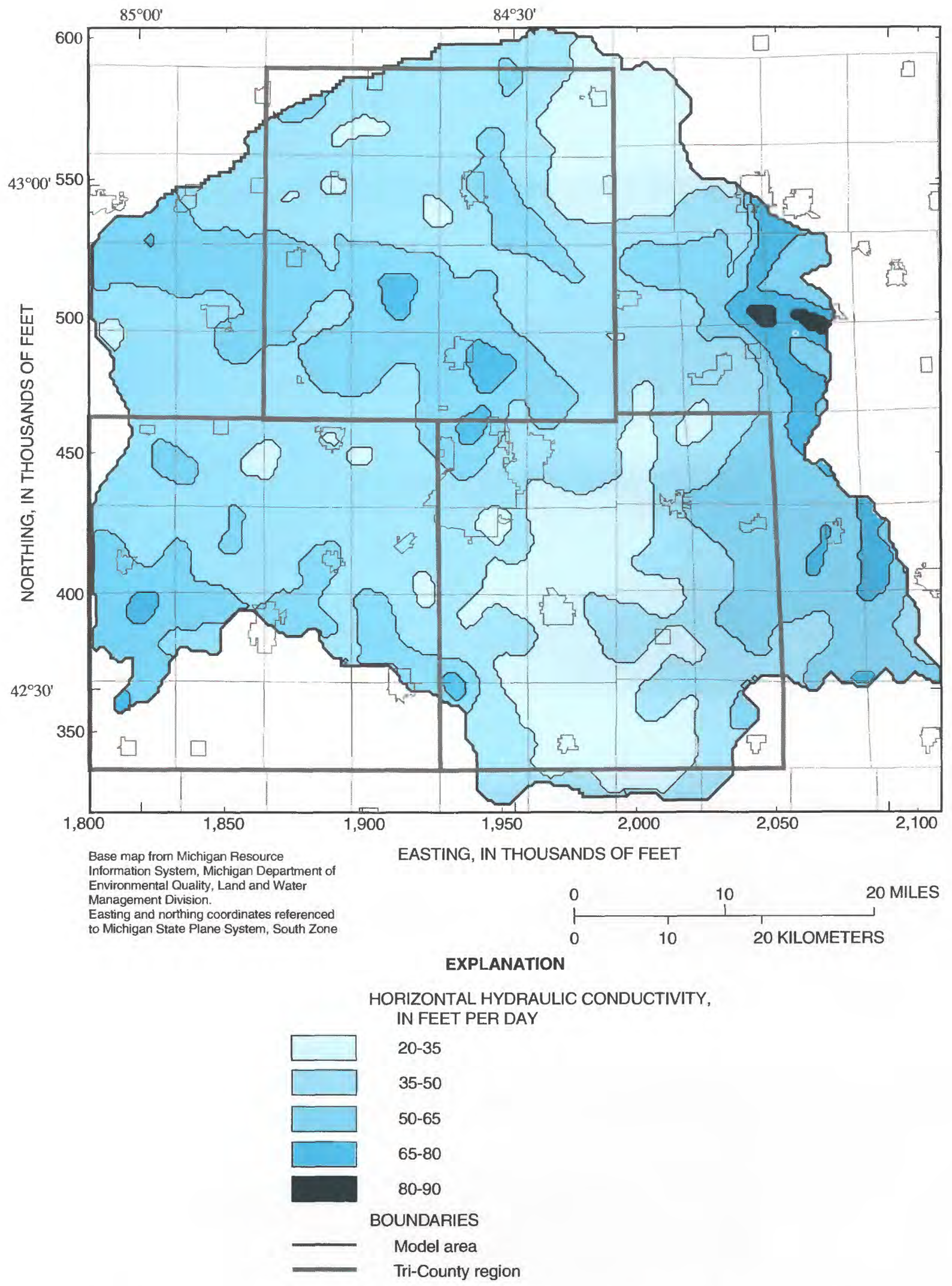

Figure 22. Estimated horizontal hydraulic conductivity in the glacial deposits in the model area, Tri-County region, Michigan. 

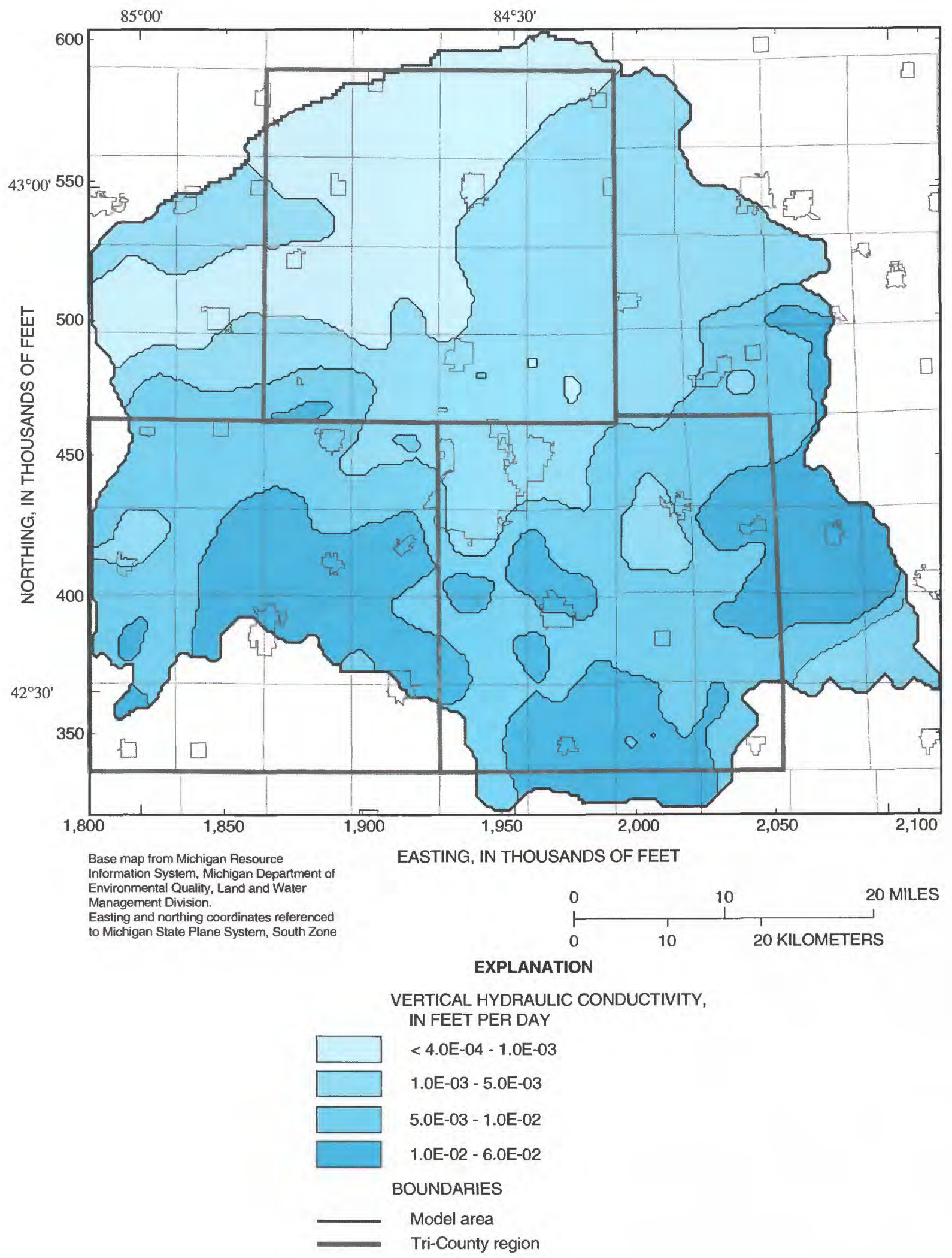

Figure 23. Estimated vertical hydraulic conductivity between the Saginaw aquifer and the glacial deposits in the model area, Tri-County region, Michigan. 


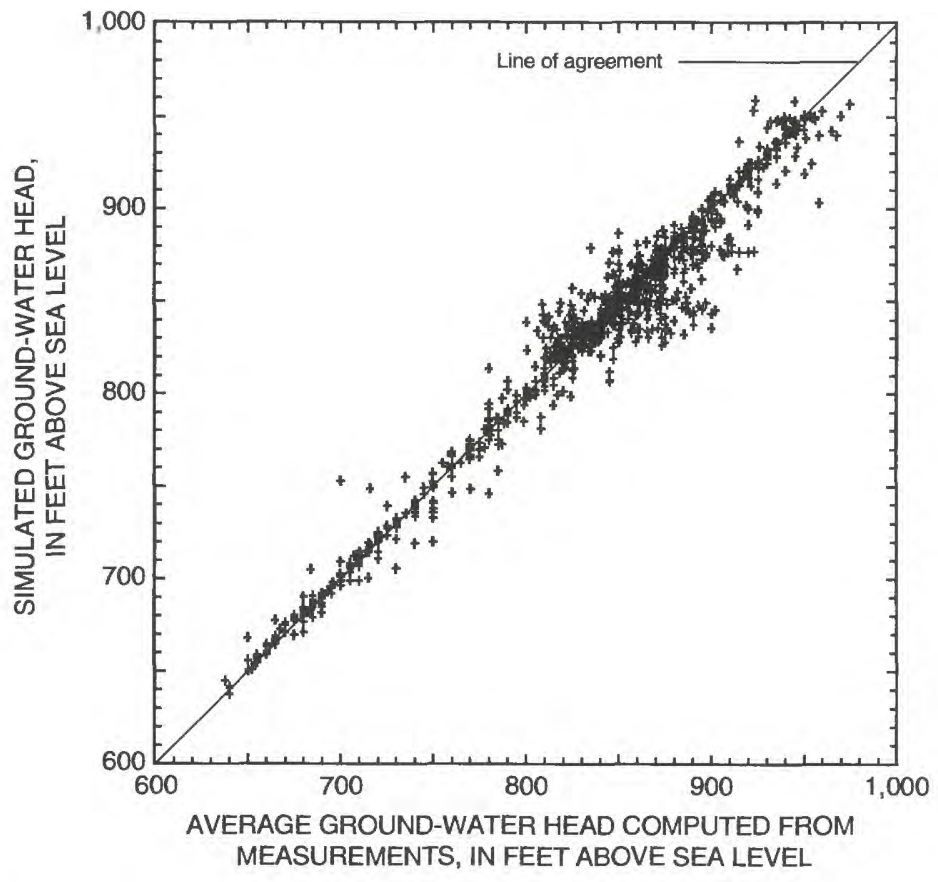

Figure 24. Relation between measured and simulated heads in cells in the glacial deposits, Tri-County region, Michigan.

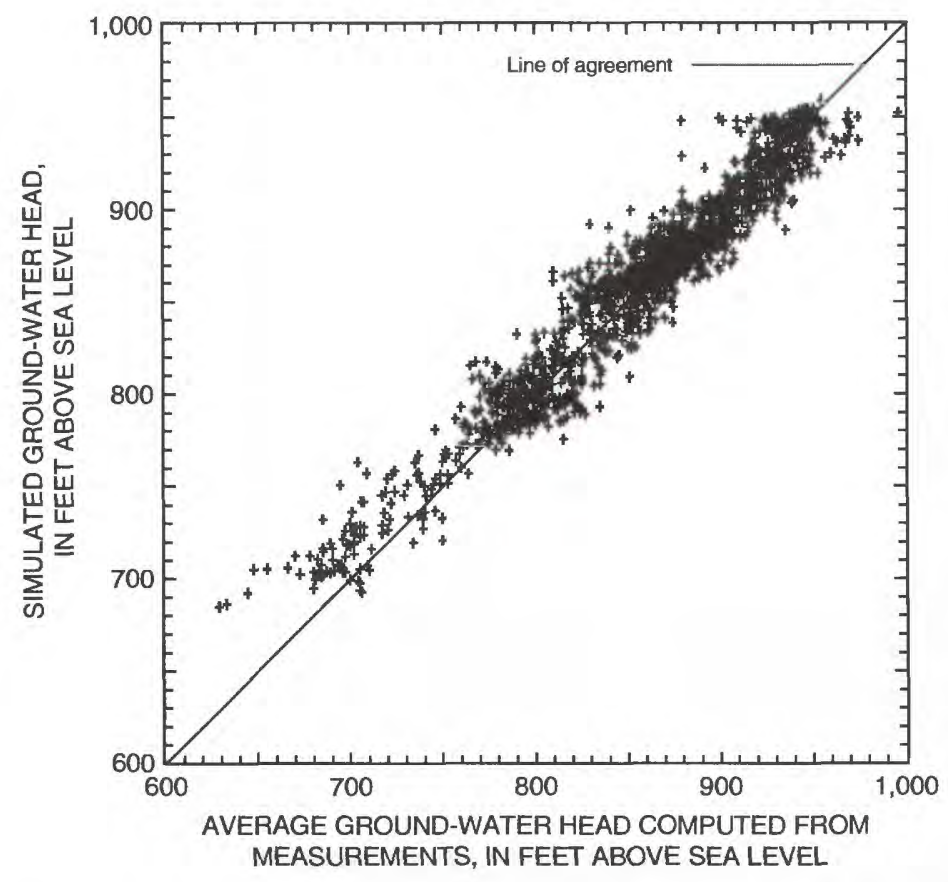

Figure 25. Relation between measured and simulated heads in cells in the Saginaw aquifer, Tri-County region, Michigan.
Ground-water flow simulations for 1992 pumping conditions were used to develop a steady-state ground-water-flow budget (fig. 29) by use of the computer program ZONEBUDGET (Harbaugh, 1990). The budget indicates that the glacial deposits receive about $6.53 \mathrm{in} / \mathrm{yr}$ of recharge from the land surface and $0.99 \mathrm{in} / \mathrm{yr}$ of recharge from streams or other surface-water bodies. Of this recharge, about $7.1 \mathrm{in} / \mathrm{yr}$ is discharged to streams either internally to the model ( $6.58 \mathrm{in} / \mathrm{yr})$ or externally $(0.52 \mathrm{in} / \mathrm{yr})$. A net discharge of $0.39 \mathrm{in} / \mathrm{yr}$ drains from the upper layer and recharges the lower layer; 0.04 $\mathrm{in} / \mathrm{yr}$ in the upper layer is withdrawn from wells. In the lower layer, approximately the same amount of water that recharges the Saginaw aquifer from the glacial deposits is withdrawn from wells. A small amount of water $(0.02 \mathrm{in} / \mathrm{yr})$ is discharged directly from the lower layer to streams. The error in the computed water balance is less than 0.05 percent.

\section{Expected Future Pumping Conditions}

Ground water from the Saginaw aquifer is the primary source of water for Tri-County residents. In 1992, more than 89 percent of the ground water withdrawn by public systems was withdrawn from the Saginaw aquifer (Luukkonen, 1995). A drought in 1988 and subsequent water rationing in the Tri-County region prompted local communities to assess the adequacy of water resources for future needs. A regional water feasibility study was done to evaluate the development of a regional water-supply system, assess the total sustainable yield of the aquifer system, and identify areas for future water supply (Tri-County Regional Planning Commission, 1992). 


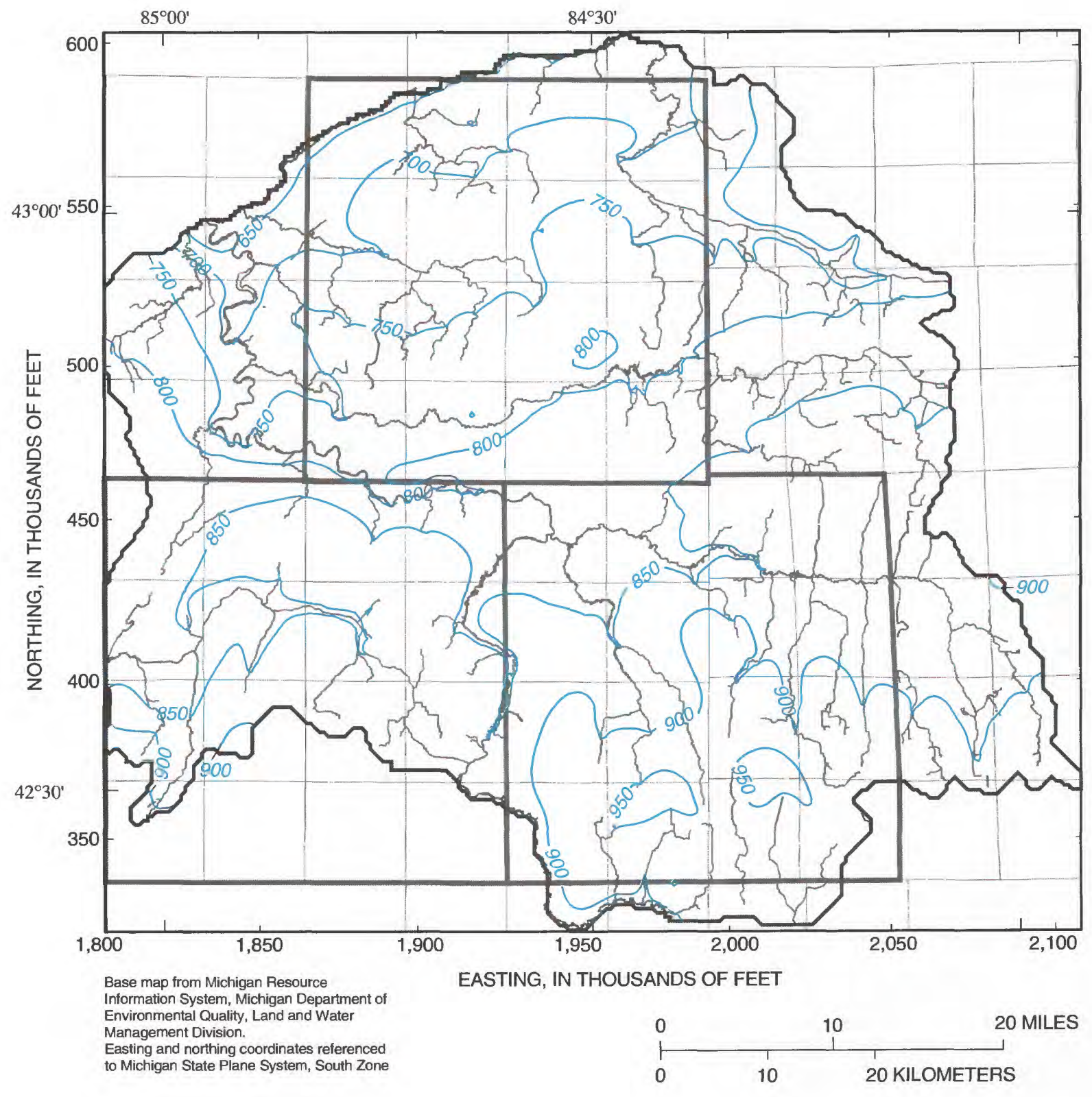

EXPLANATION
- 700 - WATER-LEVEL CONTOUR -- Shows altitude of simulated ground-water heads. Contour interval 50 feet. Datum is sea level

BOUNDARIES

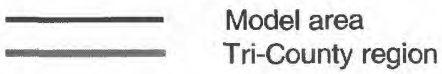

Figure 26. Simulated heads in the glacial deposits for 1992 pumping conditions in the model area, Tri-County region, Michigan. 


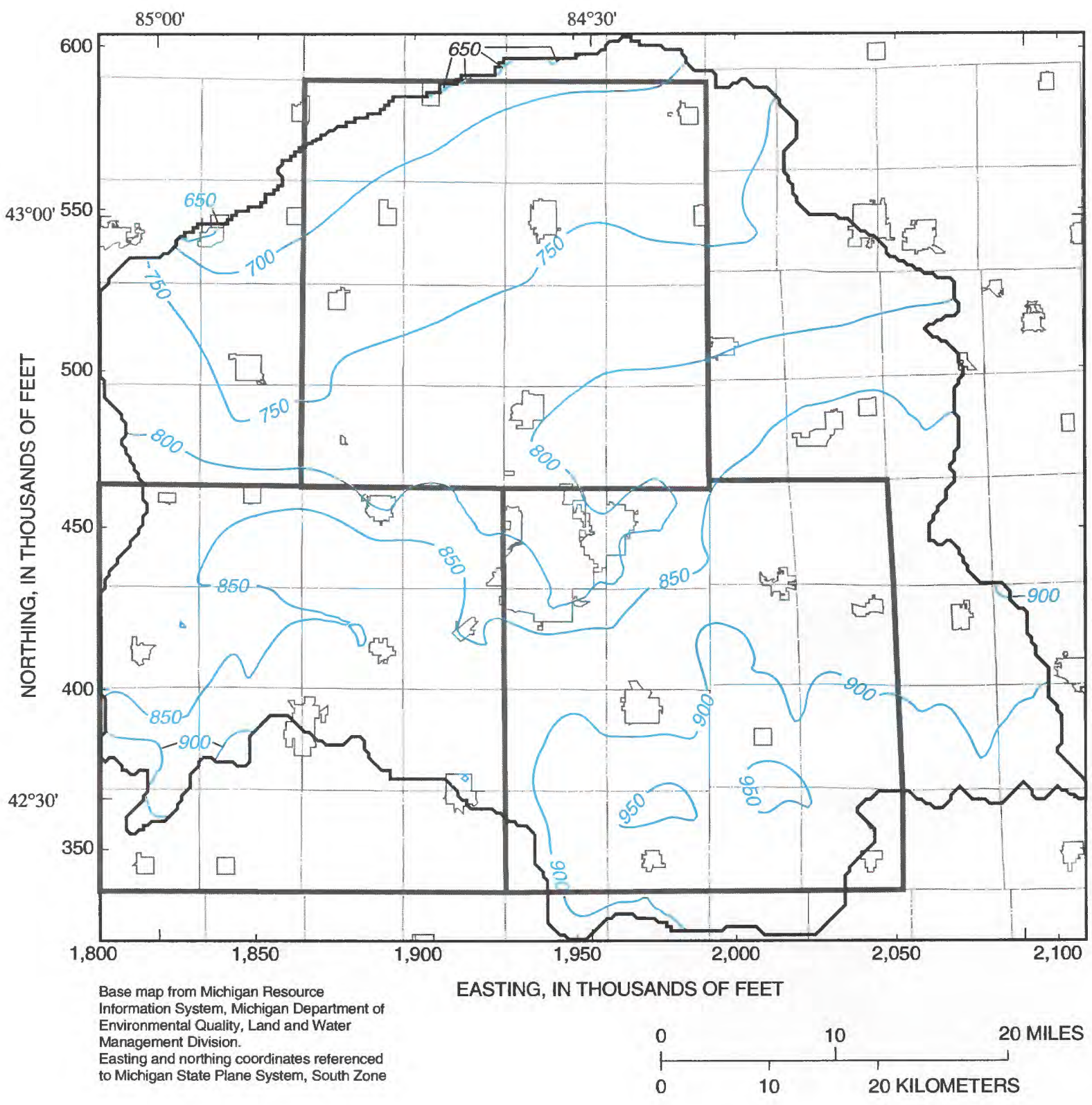

EXPLANATION

— 700 WATER-LEVEL CONTOUR -- Shows altitude of simulated ground water heads. Contour interval 50 feet. Datum is sea level

BOUNDARIES

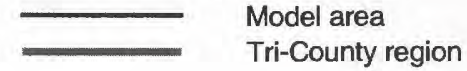

Figure 27. Simulated heads in the Saginaw aquifer for 1992 pumping conditions in the model area, Tri-County region, Michigan. 


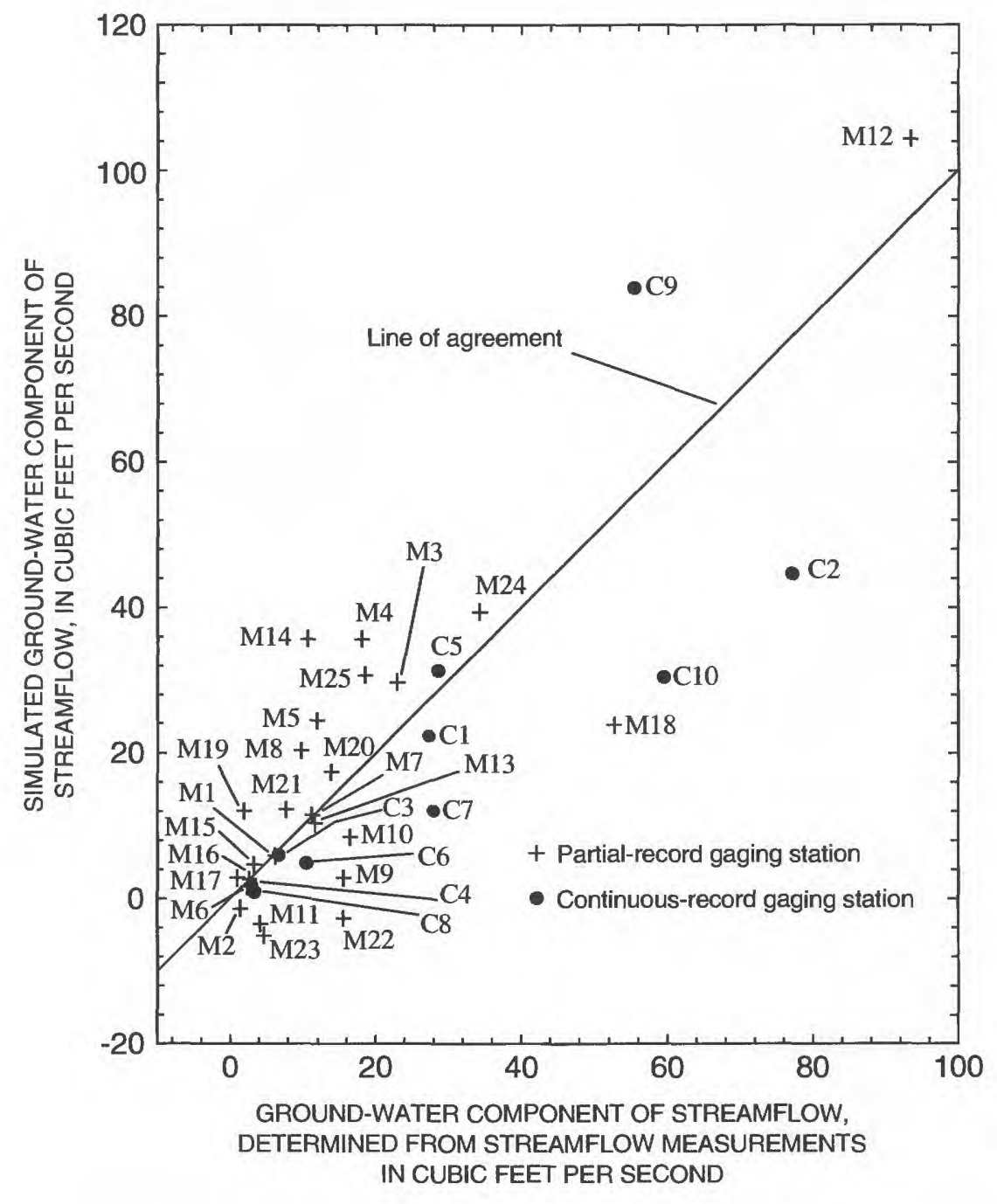

Figure 28. Relation between measured and simulated streamflow, Tri-County region, Michigan (see fig. 4 for gaging-station location).

The ability to assess the effects of alternative pumping scenarios prior to implementation is an effective ground-water management tool. Water-supply requirements were projected for the year 2020 by use of population forecasts and current per capita wateruse characteristics (Jon Coleman, Tri-County Regional Planning Commission, written commun., 1994). Three pumping scenarios were developed on the basis of these projections, the existing water-supply networks, and the projected areas of increasing demand (TriCounty Regional Planning Commission, 1992).
Scenario 1 depicts an increase in pumping from $39.9 \mathrm{Mgal} / \mathrm{d}$ in 1992 to $64.4 \mathrm{Mgal} / \mathrm{d}$ in 2020 . Hypothetical new well fields in Delhi Township and Bath Township are used to supply the additional water. Simulation results (fig. 30 ) indicate a lowering of water levels in the Saginaw aquifer from 1992 pumping conditions near the hypothetical new well fields and dewatering of an area of about $4.31 \mathrm{mi}^{2}$ in Delhi Township in the glacial deposits. 


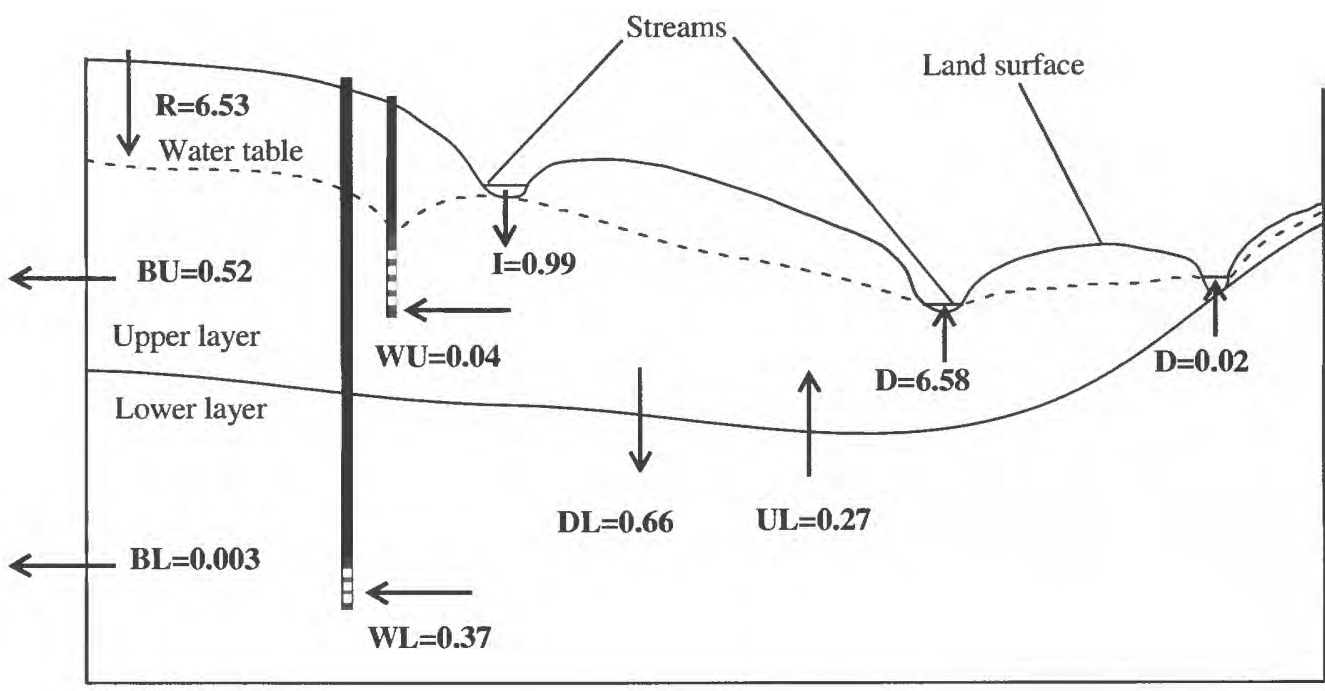

Not to scale

\section{EXPLANATION \\ (units in inches per year)}

$\begin{aligned} & \text { R } \text { Recharge } \\ & \text { BU } \text { Boundary outflow in upper layer } \\ & \text { BL } \text { Boundary outflow in lower layer } \\ & \text { WU } \text { Flow to wells in upper layer } \\ & \text { WL } \text { Flow to wells in lower layer } \\ & \text { I Infiltration from streams } \\ & \text { D Discharge to streams } \\ & \text { DL Downward flow between layers } \\ & \text { UL Upward flow between layers }\end{aligned}$

Figure 29. Ground-water model budget components for 1992 pumping conditions, Tri-County region, Michigan.

Scenario 2 depicts a total pumpage of $67.9 \mathrm{Mgal} / \mathrm{d}$ from hypothetical new well fields in Delhi Township and Delta Township. Simulation results (fig. 31) indicate that the increased withdrawals would lower ground-water levels in the Saginaw aquifer from 1992 pumping conditions near the hypothetical new well fields and dewater an area in the glacial deposits of about $4.3 \mathrm{mi}^{2}$ in Delhi Township and about $1.2 \mathrm{mi}^{2}$ in Delta Township.

Scenario 3 depicts a total pumpage of 63.7 $\mathrm{Mgal} / \mathrm{d}$ with new well fields in Delhi Township and Bath Township as well as increased pumpage at existing wells in the Tri-County region. Simulation results (fig. 32) indicate that the increased withdrawals would lower water levels in the Saginaw aquifer from 1992 pumping conditions near the hypothetical new well fields and dewater an area in the glacial deposits of about $0.06 \mathrm{mi}^{2}$ in Delta Township.

\section{Delineation of Contributing Areas}

Ground-water resources are naturally replenished by infiltration of precipitation and subsequent percolation of water through geologic materials in contributing areas. Although this process is necessary to sustain ground-water resources, it also has the potential to transport contaminants to pumped wells.

Simulated ground-water flow and estimated effective porosity values were used with a particletracking model (Pollock, 1989) to delineate contributing areas to public-supply wells. The particle-tracking program, MODPATH, uses a semianalytical particle tracking scheme. The method is based on the assumption that each directional velocity component of a water particle varies linearly within a cell in its own coordinate direction. 


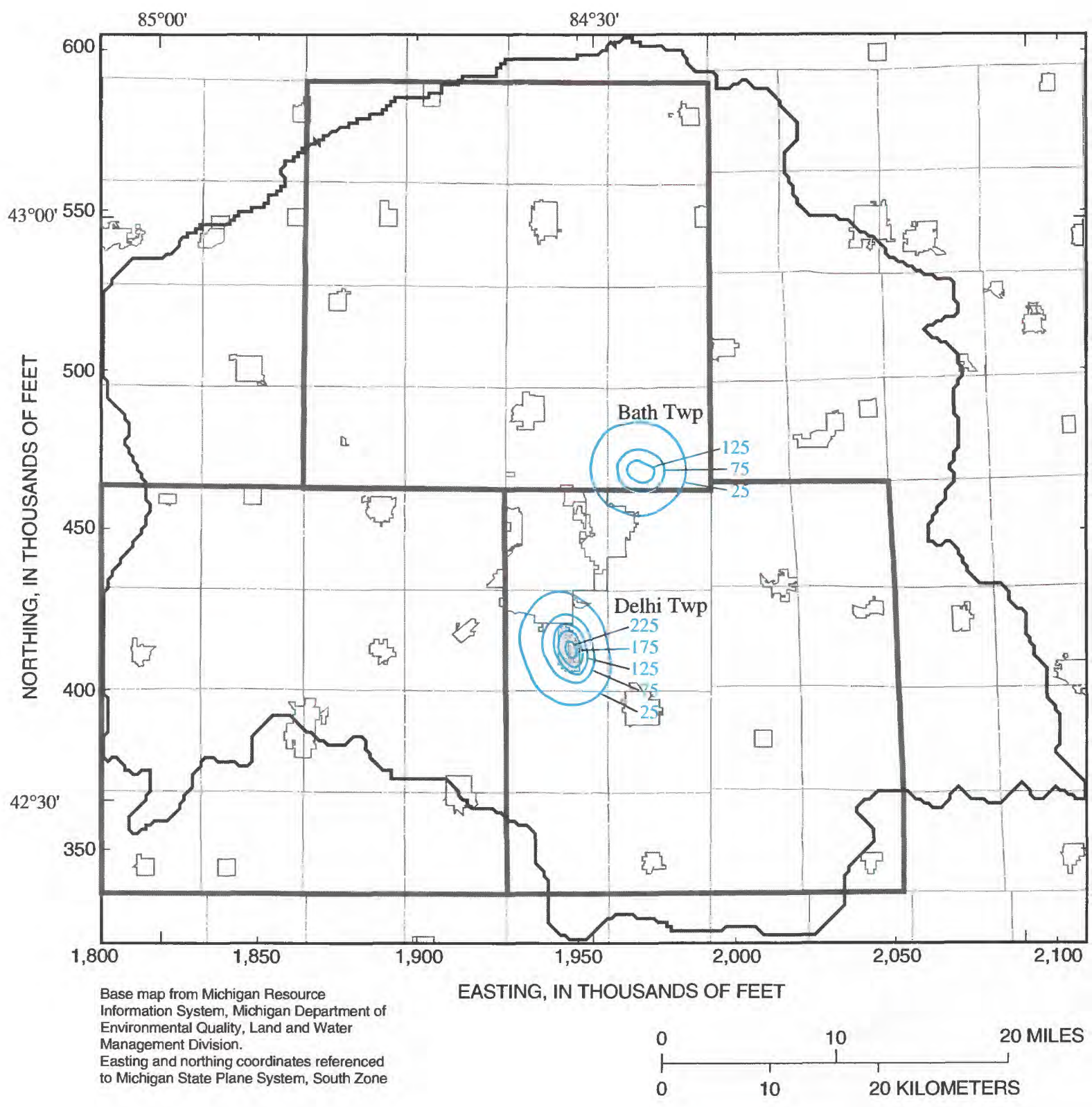

EXPLANATION

LOCATION OF DRY CELLS WITHIN THE UPPER LAYER

LINE OF EQUAL DRAWDOWN -- Shows simulated drawdown from 1992 conditions. Interval 50 feet

BOUNDARIES

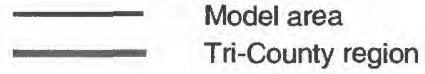

Figure 30. Simulated changes in water levels in the lower layer from 1992 conditions in the model area, Tri-County region, Michigan, resulting from implementation of scenario 1. 


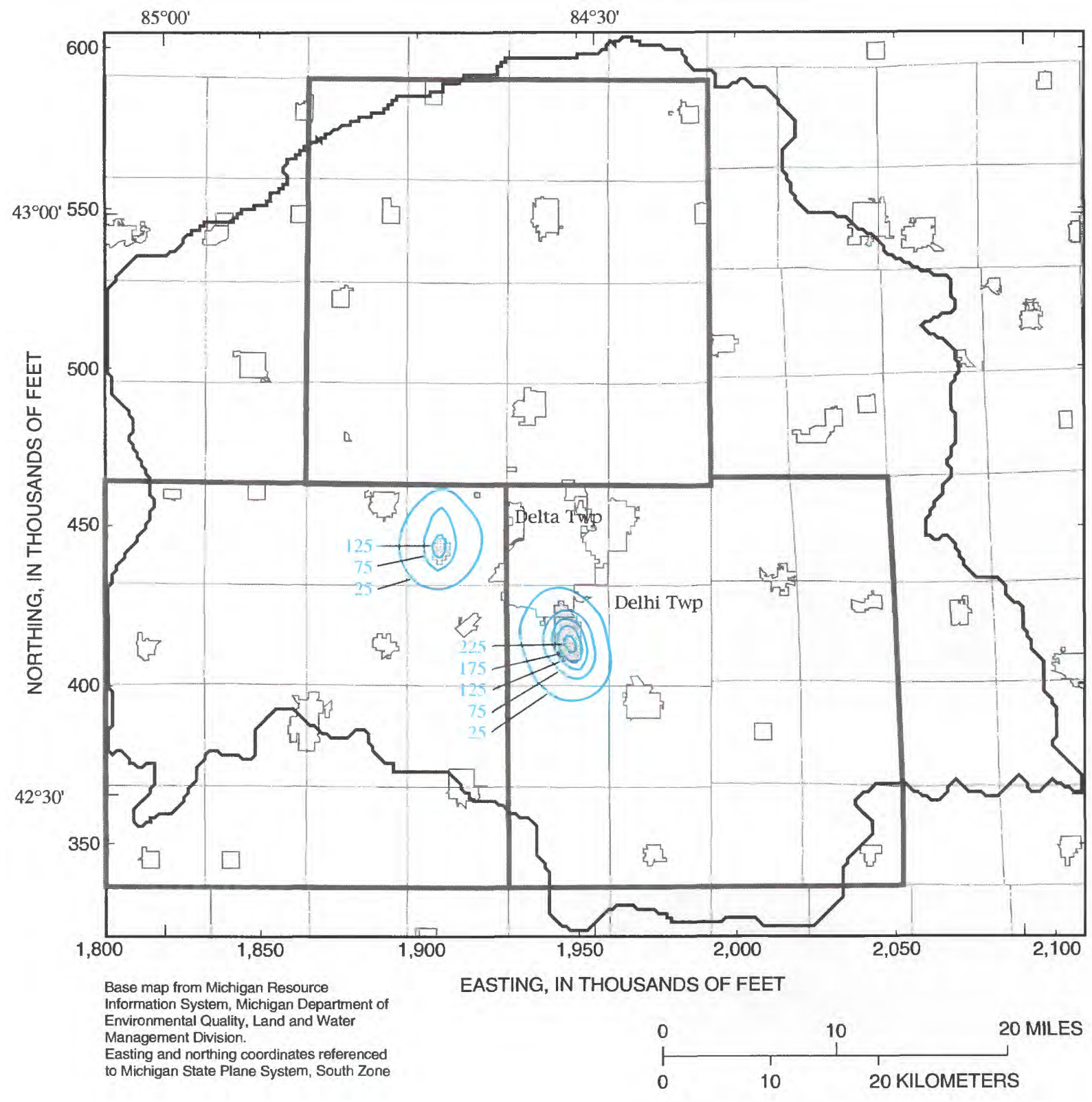

EXPLANATION

$5^{\circ} \quad$ LOCATION OF DRY CELLS WITHIN THE UPPER LAYER

- 25 - LINE OF EQUAL DRAWDOWN -- Shows simulated drawdown from 1992 conditions. Interval 50 feet

BOUNDARIES

$\longrightarrow \quad$ Model area

Figure 31. Simulated changes in water levels in the lower layer from 1992 conditions in the model area, Tri-County region, Michigan, resulting from implementation of scenario 2. 


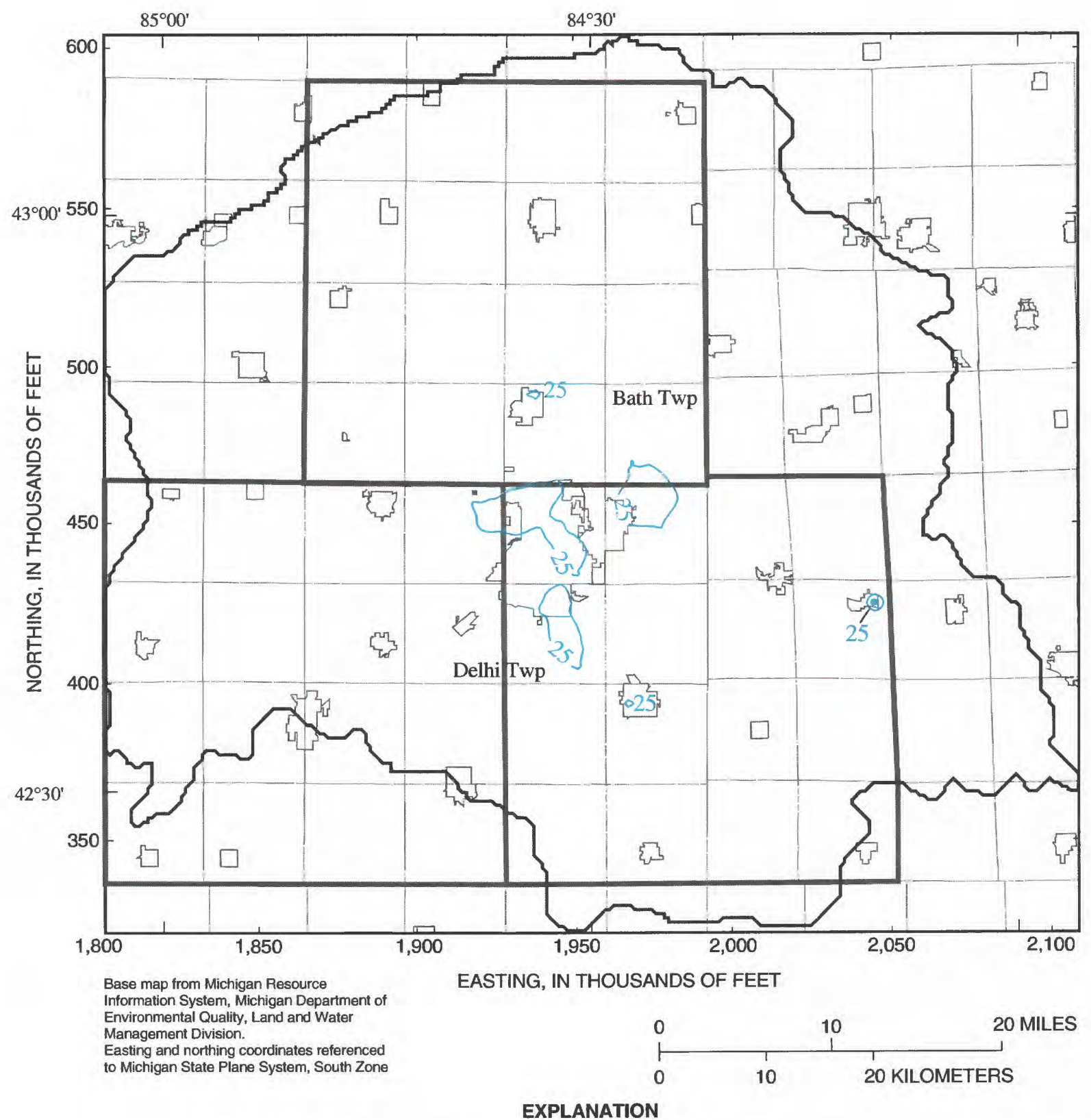

EXPLANATION

\section{BOUNDARIES \\ $-\quad$ Model area
Tri-County region}

- LOCATION OF DRY CELL WITHIN THE UPPER LAYER

- 25 - LINE OF EQUAL DRAWDOWN -- Shows simulated drawdown from 1992 conditions. Interval 50 feet

Figure 32. Simulated changes in water levels in the lower layer from 1992 conditions in the model area, Tri-County region, Michigan, resulting from implementation of scenario 3. 
This assumption allows an analytical expression describing the flow path within each cell to be obtained. The particle is then tracked as it moves from cell to cell through the steady-state three-dimensional flow system. Effective porosity, which describes the relative void (non-solid) space in a volume of geologic material, was estimated as 15 percent in the upper and the lower layer, a value consistent with the range reported by Marsily (1986, p. 36) for these types of materials.

The particle-tracking program was used by specifying locations of hypothetical water particles along the faces of cells containing one or more wells. Particles were distributed along cell faces in proportion to the total well pumpage simulated. In all, 187 wells are simulated in 161 cells of the lower model layer in the nine-township area (fig. 2); the combined withdrawal from these wells is about $32.9 \mathrm{Mgal} / \mathrm{d}$.

The particles were then tracked backward in time through the ground-water-flow velocity field until they reached a top cell face in the upper layer. Thus, the position at the end of the simulation represented the starting position of the particle. This collection of starting locations, projected up to the land surface, represents the contributing area for pumped wells.

The particle-tracking results are based on steady-state ground-water flow by advection only; dispersion is not considered. Qualitatively, however, the effects of dispersion would enlarge the contributing areas.

Pumping conditions in 1992 were simulated by distributing 87,779 particles along the faces of cells containing one or more public-supply wells. The contributing area for these wells encompasses 1,929 model cells, or total of about $121 \mathrm{mi}^{2}$, and consists of disconnected zones in the central and south-central parts of the model area (fig. 33). In addition, 40-year time-of-travel areas, identified by those particles whose time of travel is 40 years or less, are delineated by the positions of 32,032 particles (fig. 34 ). The 40 year time-of-travel areas encompass 668 model cells or a total of about $42 \mathrm{mi}^{2}$ and consist of disconnected zones in the central part of the model area.

\section{Use of Tritium Data to Confirm Particle- Tracking Results}

Tritium $\left({ }^{3} \mathbf{H}\right)$ is a radioactive isotope of hydrogen. Tritiated water has physical and chemical properties similar to those of non-tritiated water. Tritium is produced naturally at low levels by reactions between cosmic rays and water in the upper atmosphere. Payne (1972) estimates that tritium concentrations in precipitation ranged from 5 to 20 tritium units ${ }^{2}$ (TU) before 1952. On the basis of this estimated range, natural concentrations of tritium in ground water that is 41 years old (from 1952 to the reference date of 1993) would naturally decrease through radioactive decay to 0.5 to 2.0 TU, based on the half-life of ${ }^{3} \mathrm{H}$ of 12.3 years.

In late 1952, large quantities of tritium were introduced into the atmosphere at the beginning of atomic testing in the atmosphere. The resulting elevated concentrations of tritiated water provide a marker that can be used to date ground water. Thus, ground water whose tritium concentration is greater than $2.0 \mathrm{TU}$ would be expected to have entered the ground water system less than 41 years ago.

In the Tri-County region, water from 51 wells was sampled for tritium during three investigations (fig. 35). Slayton (1982) sampled 18 wells in the southern half of the model area; water from 9 of these wells had tritium concentrations exceeding $2.0 \mathrm{TU}$. Ritter (1980) sampled 12 wells in Meridian Township near the center of the model area; water from 8 of these wells had tritium concentrations exceeding 2.0 TU. During this investigation, 21 wells were sampled throughout the model area; water from 11 of these wells had tritium concentrations exceeding $2.0 \mathrm{TU}$.

Particle-tracking analysis was used to estimate the time of travel to the 51 wells sampled for tritium. Particles were placed on the faces of cells containing sampled wells. Each selected cell contained 1,125 particles. During the simulation, particles were tracked backward in time from the selected cells to the upper cell face in the upper layer; thus, the position at the end of the simulation represented the starting position of the particle. Particles that took 41 years or less to travel from the upper cell face in the upper layer to the cells containing the sampled wells represent water recharging the aquifer since 1952.

\footnotetext{
${ }^{2} \mathrm{~A}$ tritium unit (TU) is equal to 1 tritium atom in $10^{18}$ atoms of hydrogen.
} 


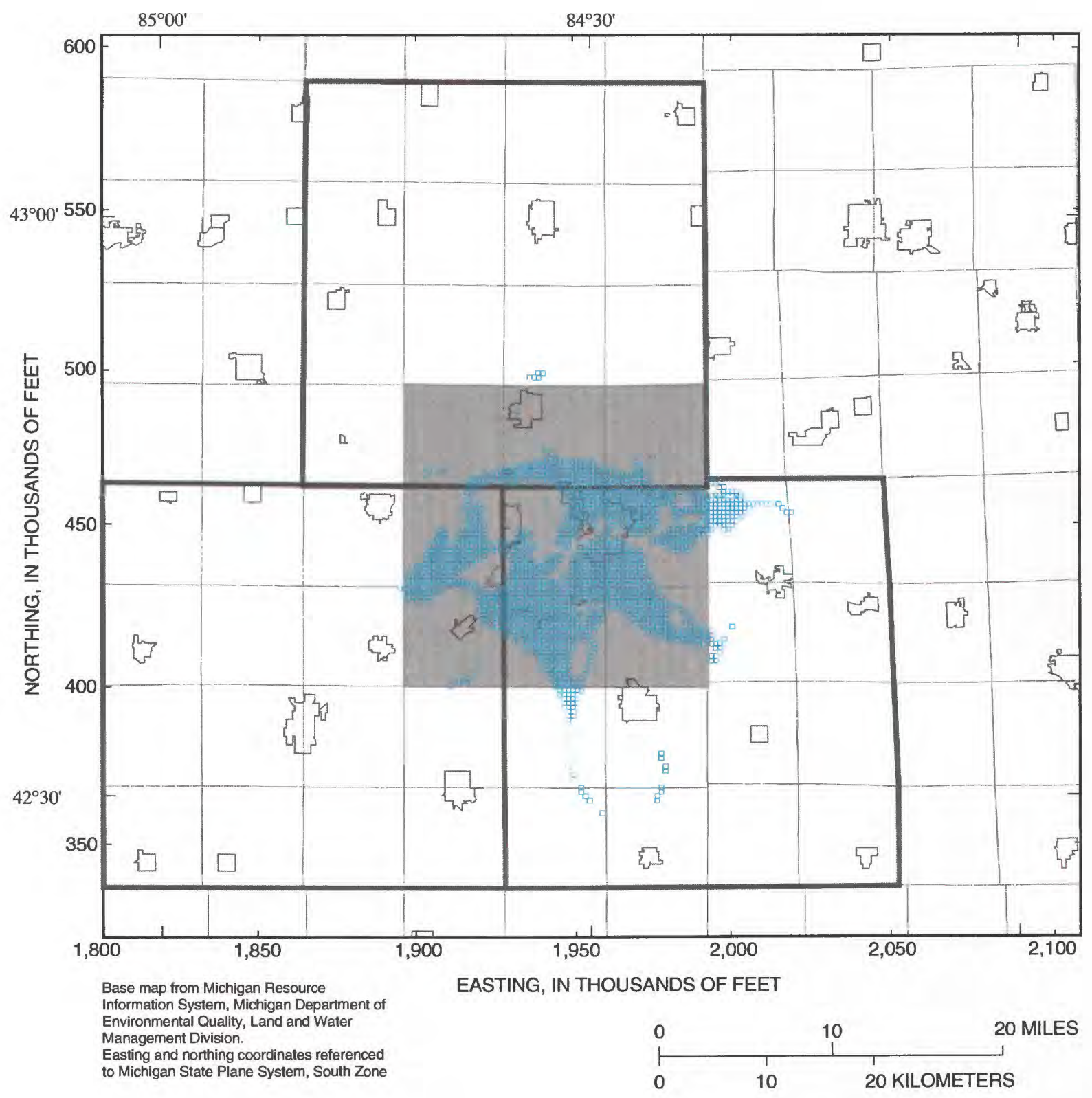

EXPLANATION

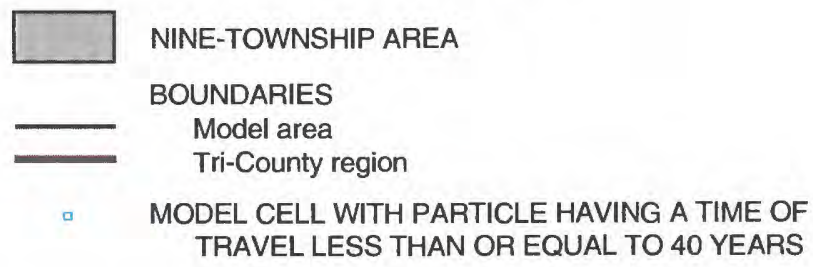

Figure 33. Simulated contributing areas of public-supply wells in the nine-township area, Tri-County region, Michigan. 


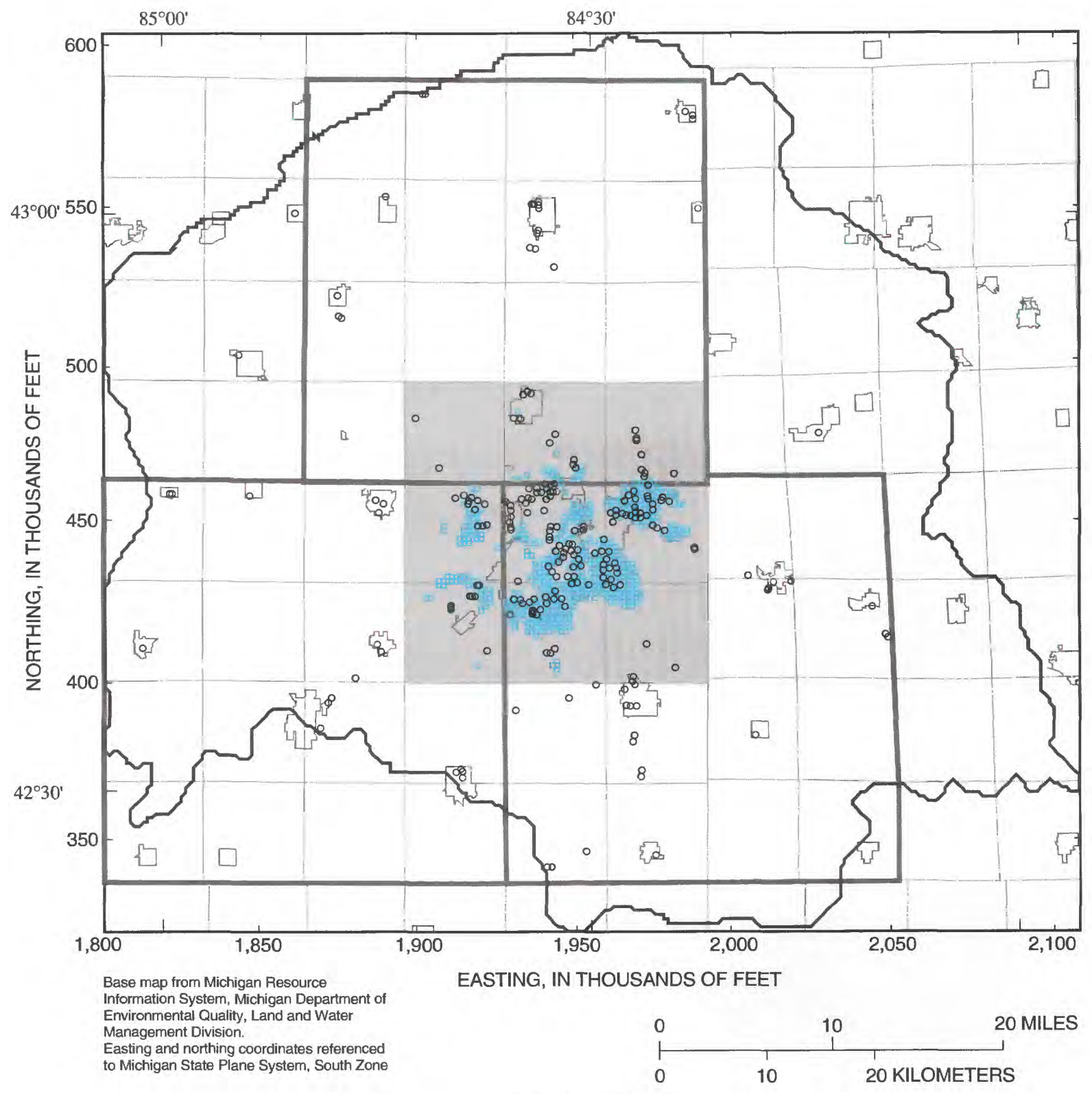

EXPLANATION

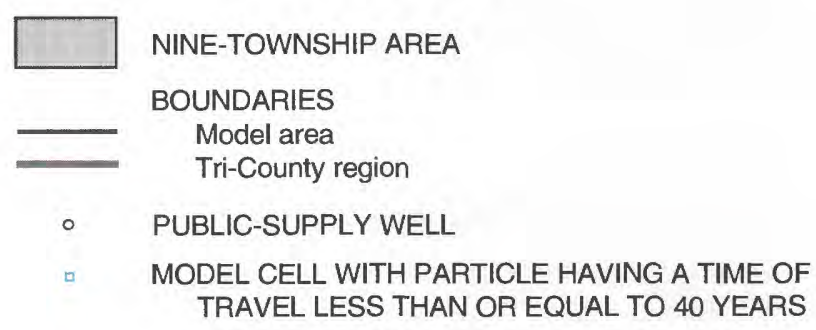

Figure 34. Simulated 40-year time-of-travel areas for public-supply wells in the nine-township area, Tri-County region, Michigan. 


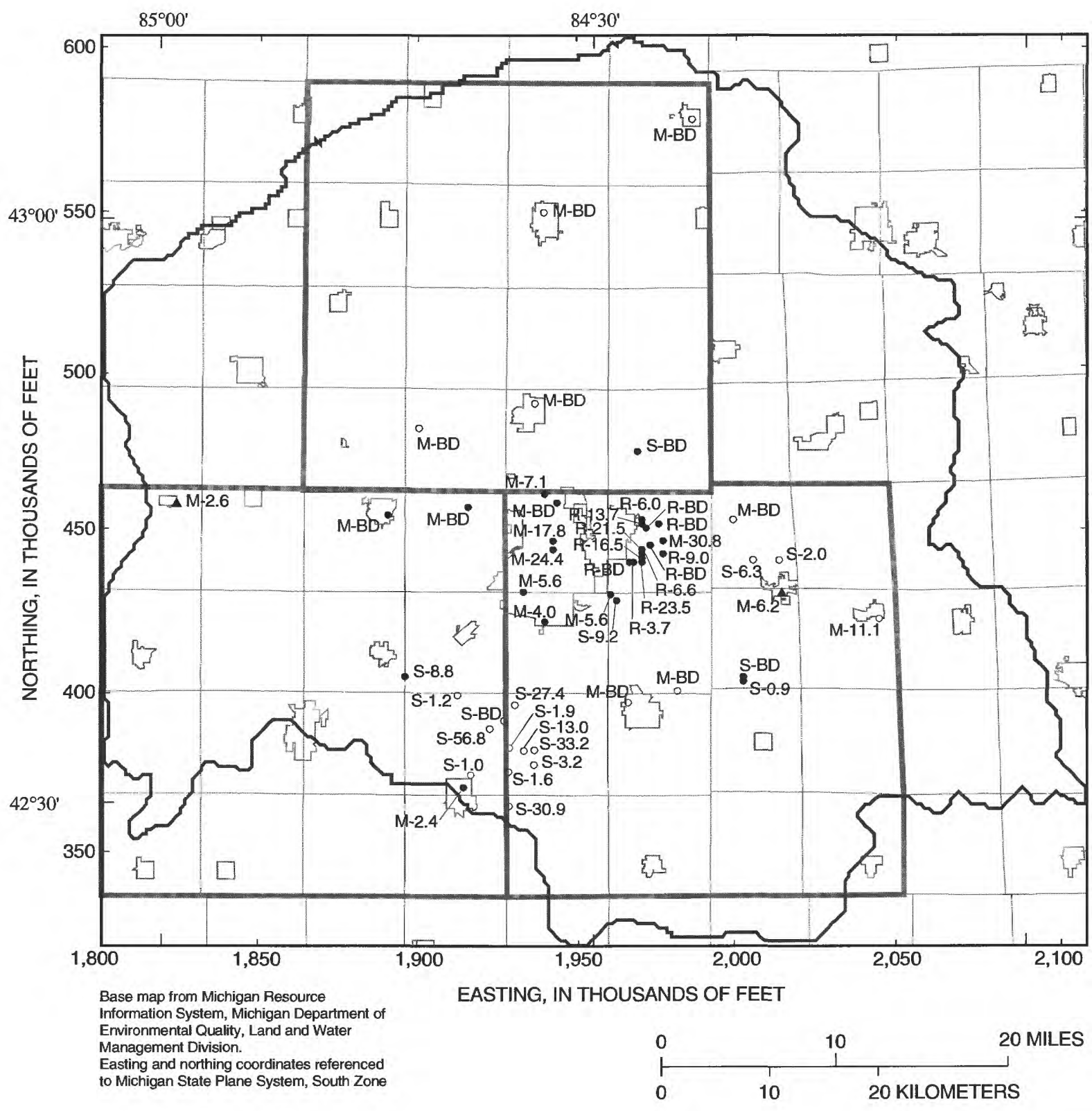

EXPLANATION

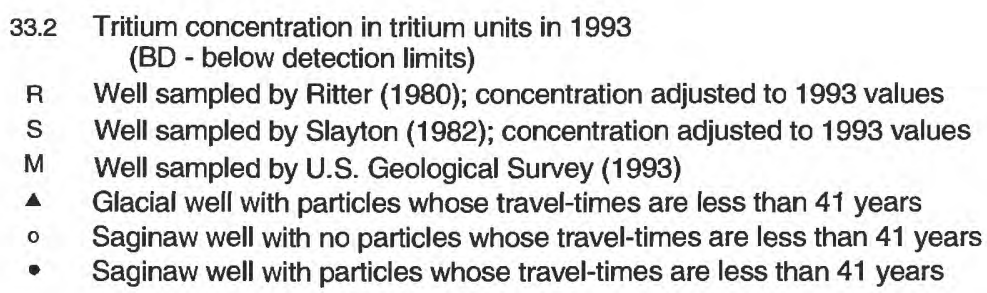

Figure 35. Tritium concentrations and particle-tracking results for sampled wells in the model area, Tri-County region, Michigan. 
Time-of-travel estimates obtained from the particle-tracking analysis were compared with tritium concentrations of water from sampled wells. Particletracking results from 51 wells throughout the model area indicate that 33 wells are correctly classified and 18 are not. That is, water from 33 wells either had greater than $2.0 \mathrm{TU}$ and particles reaching the wells in less than 41 years or had less than or equal to $2.0 \mathrm{TU}$ and no particles reaching the wells in less than 41 years. Those that are incorrectly classified either had greater than $2.0 \mathrm{TU}$ and no particles reaching the wells in less than 41 years or had less than or equal to 2.0 TU and particles reaching the wells in less than 41 years. For two wells, fewer than 100 particles (38 and 40 particles) reached the land surface in less than 41 years; whereas for the rest, more than 200 particles reached the land surface in less than 41 years. Contingency-table analysis of these results indicate that this degree of concordance could occur with a probability $(p)$ less than 0.05 , based on a Chi-square statistic $\left(X^{2}\right)$ of 4.07 . In the nine-township area, where 28 wells were sampled, 20 are correctly classified and 8 are misclassified $\left(p<0.05, X^{2}=4.23\right)$. Thus, in the whole model area and in the nine-township area where most of the ground water is being withdrawn, the results of the tritium sampling support the effectiveness of the particle-tracking analysis. Finally, for the 21 wells sampled during this investigation throughout the model area, 17 are correctly classified and 4 are misclassified $\left(p<0.005, X^{2}=8.24\right)$. Thus, where the reliability of the sampling protocols and analytical techniques could be readily verified, the results of the tritium sampling support the results of the particle-tracking analysis.

Some of the discrepancies between the results of tritium sampling and those of particle-tracking analysis are likely associated with (1) sampling of water from wells that do not fully penetrate the aquifer and (2) the model conceptualization of the Saginaw aquifer as a single continuous unit. Because the Saginaw aquifer is formed from a composite of sandstone units, tritium concentrations may vary with depth. Moreover, the particle-tracking analysis does not account for dispersion, which likely affects tritium distribution.

\section{Limitations of Model Results}

The ground-water-flow model was developed to simulate the regional, steady-state response of the Saginaw aquifer in the Tri-County region to groundwater withdrawals typical of those applied in 1992.
Flow in the Saginaw aquifer is modeled as a single layer whose properties are based on the composite thickness of the sandstone units in the Pennsylvanian rocks. However, the various sandstone units are separated by less permeable materials that likely affect local flow and head characteristics. Anyies. Local flows over distances smaller than the dimensions of the grid cell cannot be accurately represented. Additional geologic and hydraulic data, as well as finer discretization of the model, would be needed to simulate local flow systems. The accuracy of the model is limited by the data available to estimate the transmissivity of the Saginaw aquifer, the horizontal hydraulic conductivity of the glacial deposits, the vertical hydraulic conductivity between the Saginaw aquifer and the glacial deposits, and the streambed conductance. Initial estimates of hydraulic properties were interpolated by analysis of available data. However, the interpolation process produces estimates of hydraulic properties that are less variable than the corresponding properties in nature.

Model simulations are restricted to steady-state conditions. All stresses within and inputs to the system, including well pumpages and recharge, remain constant throughout the simulation. No net gain or loss of flow is simulated in the system. Recharge from precipitation or flow into the model area across external boundaries equals flow to streams, lakes, and wells and flow out of the model area across external boundaries. Implicit in the steady-state assumption is that measured heads and flows represent long-term average conditions, because true steadystate conditions do not occur. Changes in storage of water in the aquifers are not accounted for in steadystate simulations. Thus, the current configuration of the ground-water-flow model cannot be used to simulate transient-flow conditions.

External boundary conditions were specified on the basis of natural hydrologic conditions and pumping stresses in 1992; however, use of the model to simulate ground-water withdrawals near an external boundary cell may change the boundary conditions and produce inaccurate results. Simulated well pumpages were assumed to come from the centers of the grid cells. Small pumpages from domestic wells were not included owing to the difficulty in obtaining reliable data and the limitations in accurately representing small scale flow systems. 
The accuracy of the particle-tracking results are limited by the accuracy of the flow model, the estimates of the effective porosity of the flow system, the linear approximation of the cell flow velocities to the local ground-water flow velocities, and the assumption of no dispersion. The model does not explicitly describe flow through fractures or fissures in the rocks, but it implicitly combines primary and secondary permeability components to describe average flow conditions. The presence of fractures and fissures could create large heterogeneities in local hydraulic properties and could result in large discrepancies between simulated and actual times of travel for various constituents. Particle tracking was done for the ninetownship area near the center of the model area. Attempts to apply the results of additional particle tracking results for wells near the boundaries of the model area would be inappropriate. Likewise, detailed analysis of contributing areas for a small, localized area might not produce reliable results because of the inability of the model to represent local flow systems.

\section{SUMMARY}

A ground-water-flow model was developed to simulate the regional, steady-state response of the Saginaw aquifer to major ground-water withdrawals in the Tri-County region surrounding Lansing, Michigan. Ground water from the Saginaw aquifer is the primary source of water for Tri-County residents. In 1992, more than 89 percent of the ground water withdrawn by public systems was pumped from the Saginaw aquifer. Aquifers in the glacial deposits and other bedrock units also are important ground-water sources in some locations.

The Saginaw aquifer is in the Grand River and Saginaw Formations of Pennsylvanian age. These formations, which are primarily sandstone, range in thickness from 0 to $300 \mathrm{ft}$, and are thickest in the northern part of the Tri-County region. Glacial deposits, left by ice advances during late Wisconsin time ( 35,000 to 10,000 years before the present), overlie the Saginaw aquifer. These deposits range in texture from lacustrine clay or glacial till to coarse alluvial and outwash deposits. The glacial deposits range in thickness from 0 to 300 feet and are thickest in the northwestern part of the Tri-County region.

Ground-water flow in the glacial deposits is generally from south to north. The spatial variation of recharge to the glacial deposits, which averaged
$6.7 \mathrm{in} / \mathrm{yr}$, was estimated on the basis of regional relations determined for the Lower Peninsula of Michigan (Holtschlag, 1994). Initial estimates of the spatial variation in the horizontal and vertical hydraulic conductivities in the glacial deposits were determined on the basis of a geostatistical analysis of lithologic data from 4,947 wells. Flow between the glacial deposits and the Saginaw aquifer was assumed to be related to the vertical hydraulic conductivity of the glacial deposits.

Ground-water flow in the Saginaw aquifer also is primarily from south to north. Recharge to the Saginaw aquifer is principally by leakage from the glacial deposits; discharge is primarily to regional river systems, such as Maple River. The spatial variation of transmissivity in the Saginaw aquifer was associated with the composite thickness of sandstone units in the Pennsylvanian rock. The Saginaw confining unit was assumed to prevent flow of ground water between the Saginaw aquifer and underlying units.

The ground-water-flow model developed for the Tri-County region consists of two layers; the upper layer represents aquifers in the glacial deposits and the lower layer represents the Saginaw aquifer. The model area is horizontally discretized into a grid of equally spaced cells in 215 rows and 233 columns. Each cell is 1,320 by $1,320 \mathrm{ft}$. Constant-head and no-flow cells are used as external boundaries for the model; constanthead river cells and public-supply wells are primarily used as internal boundaries.

The model was calibrated by estimating four parameters by use of nonlinear regression. Three parameters adjust initial estimates of the spatial variations in aquifer hydraulic properties, and one parameter estimates streambed conductance. After application of the three parameters to the matrices of initial estimates, the resulting transmissivities of the Saginaw aquifer range from 75.7 to $3,430 \mathrm{ft}^{2} / \mathrm{d}$; horizontal hydraulic conductivities of the glacial deposits range from 22.3 to $87.5 \mathrm{ft} / \mathrm{d}$; and vertical hydraulic conductivities of the glacial deposits range from $4.7 \times 10^{-4}$ to $4.0 \times 10^{-2} \mathrm{ft} / \mathrm{d}$. Streambed hydraulic conductivity was estimated as $2.3 \mathrm{ft} / \mathrm{d}$. No significant correlation was found among estimated parameters. However, because of nonlinearities detected by Beale's measure, reliable confidence intervals for parameters could not be computed.

The regression analysis improved on initial parameter estimates by minimizing the weighted residuals formed as the differences between 2,791 head measurements and 35 ground-water flow 
estimates and simulated values. Measurements were weighted to account for differences in units of measurement between heads (in feet) and flows (in cubic feet per second), differences in the numbers of head and flow data, and differences in accuracies among head and flow data. Analysis of model simulation results for 1992 pumping conditions indicate that 50 percent of simulated head values are within about $3 \mathrm{ft}$ of measured values for the upper layer and within about $9 \mathrm{ft}$ for the lower layer; 90 percent are within about $21 \mathrm{ft}$ of measured values for the upper layer and within about $25 \mathrm{ft}$ for the lower layer. Simulation results also indicate that 50 percent of the simulated streamflows are within about $7 \mathrm{ft}^{3} / \mathrm{s}$ and 90 percent are within $29 \mathrm{ft}^{3} / \mathrm{s}$ of estimated streamflow estimates.

Three scenarios were simulated for alternative pumping conditions projected for the year 2020. The scenarios represent an average increase of 64 percent over 1992 pumping withdrawals. The results show areas where ground-water levels are expected to be lowered from 1992 conditions if the scenarios are implemented.

Contributing areas were delineated for public supply wells in the Saginaw aquifer in the ninetownship area, which is near the center of the TriCounty region. Contributing areas were delineated by use of particle-tracking analysis. Results of flow simulations under 1992 pumping conditions indicate that these areas cover about $121 \mathrm{mi}^{2}$. Contributing areas for particles whose traveltimes are 40 years or less cover about $42 \mathrm{mi}^{2}$. An estimate of effective porosity of 15 percent for the Saginaw aquifer and for the glacial deposits was used in the computations.

Tritium concentrations of water from 51 wells in the Tri-County region were used to confirm the delineation of 40-year contributing areas. Tritium data indicate whether sampled ground water recharged the system before atmospheric atomic testing began in 1952. Results of tritium sampling support results of model simulations for wells sampled throughout the model area, the nine-township area, and during this study. Some of the discrepancies between the results of tritium sampling and model simulations are thought to be associated with sampling from wells that are not fully penetrating the aquifers and differences in sampling and analytical procedures between this study and studies done more than 10 years earlier.

\section{REFERENCES CITED}

Baltusis, M.A., Quigley, M.F., and Mandle, R.J., 1992, Municipal ground-water development and withdrawals in the central lower peninsula of Michigan, 18701987: U.S. Geological Survey Open-File Report 91-215, $89 \mathrm{p}$.

Cooley, R.L., and Naff, R.L., 1990, Regression modeling of ground-water flow: U.S. Geological Survey Techniques of Water-Resources Investigations, book 3, chap. B4, 232 p.

Cressie, Noel, 1991, Statistics for spatial data: New York, John Wiley, $900 \mathrm{p}$.

Eichenlaub, V.L., Harman, J.R., Nurnberger, F.V., and Stolle, H.J., 1990, The climatic atlas of Michigan: Notre Dame, Indiana, The University of Notre Dame Press, $165 \mathrm{p}$.

Freeze, R.A., and Cherry, J.A., 1979, Groundwater: Englewood Cliffs, New Jersey: Prentice-Hall, Inc., $604 \mathrm{p}$.

Geraghty \& Miller, Inc., 1993, MODELCAD 386, Computer aided design software for groundwater modeling: Reston, Virginia, Geraghty \& Miller, Inc., 196 p

Harbaugh, A.W., 1990, A computer program for calculating subregional water budgets using results from the U.S. Geological Survey Modular three-dimensional finite-difference ground-water flow model: U.S. Geological Survey Open-File Report 90-392, 46 p.

Hill, M.C., 1992, A computer program (MODFLOWP) for estimating parameters of a transient, threedimensional, ground-water flow model using nonlinear regression: U.S. Geological Survey Open-File Report 91-484, 358 p.

Hill, M.C., 1994, Five computer programs for testing weighted residuals and calculating linear confidence and prediction intervals on results from the groundwater parameter-estimation computer program MODFLOWP: U.S. Geological Survey Open-File Report 93-481, 81 p. 
Hirsch, R.M., 1982, A comparison of four streamflow record extension techniques: Water Resources Research, v. 18, no. 4, pp. 1081-1088.

Holtschlag, D.J., 1994, A generalized estimate of groundwater recharge rates in the lower peninsula of Michigan: U.S. Geological Survey Water-Supply Paper $2437,81 \mathrm{p}$.

Keckler, Doug, 1994, Surfer for Windows, user's guide: Golden, Colo., Golden Software, 446 p.

Luukkonen, C. L., 1995, Ground-water withdrawals in Clinton, Eaton, and Ingham counties, Michigan: U.S. Geological Survey Fact Sheet 226-95.

Mandle, R.J., and Westjohn, D.B., 1988, Geohydrologic framework and ground-water flow in the Michigan basin in Swain, L.A., and Johnson, A.I., eds., Regional aquifer systems of the United States, Aquifers of the Midwestern area: 24th Annual Conference of American Water Resources Assoc., Milwaukee, Wisc., 1988, AWRA Monograph Series 13, pp. 83-109.

Marsily, Ghislain de, 1986, Quantitative hydrogeology: New York, Academic Press, 440 p.

McDonald, M.G., and Harbaugh, A.W., 1988, A modular three-dimensional finite-difference ground-water flow model: U.S. Geological Survey Techniques of Water-Resources Investigations, Book 6, Chap. A1, $576 \mathrm{p}$.

Payne, B.R., 1972, Isotope hydrology: Adv. Hydrosci, v. 8, p. 95-138.

Pollock, D.W., 1989, Documentation of computer programs to compute and display pathlines using three Dimensional finite-difference ground-water flow model: U.S. Geological Survey Open-File Report 89-381, $188 \mathrm{p}$.

Ritter, M.H., 1980, The use of tritium for confirming areas of groundwater recharge, Meridian Township, Michigan: East Lansing, Michigan State University, M.S. Thesis, $26 \mathrm{p}$.

Rutledge, A. T., 1993, Computer programs for describing the recession of ground-water discharge and for estimating mean ground-water recharge and discharge from streamflow records: U.S. Geological Survey Water-Resources-Investigations Report 93-4121, $45 \mathrm{p}$.
Rutledge, A.T., and Daniel, III, C.C., 1994, Testing an automated method to estimate ground-water recharge from streamflow records: Ground water, v. 32, no. 2, March-April, p. 180-189.

Slayton, D.S., 1982, Field evidence for shale membrane filtration of groundwater, south-central Michigan: East Lansing, Michigan State University, M.S. Thesis, $80 \mathrm{p}$.

Tri-County Regional Planning Commission, 1992, TriCounty regional water feasibility study: Burns and McDonnell; Snell Environmental Group; and Dickinson, Wright, Moon, Van Busen, and Freeman Report 90-338-4-005.

U.S. Department of Commerce, 1991, 1990 Census of population and housing: Summary population and housing characteristics for Michigan: Bureau of the Census, Economics and Statistics Administration Report 1990 CPH-1-24.

Vanlier, K.E., Wood, W.W., and Brunett, J.O., 1973, Water-supply development and management alternatives for Clinton, Eaton, and Ingham Counties, Michigan: U.S. Geological Survey Water-Supply Paper 1969, $111 \mathrm{p}$.

Westjohn, D.B., Weaver, T.L., and Zacharias, K.F., 1994, Hydrogeology of Pleistocene glacial deposits and Jurassic "Red Beds" in the central Lower Peninsula of Michigan: U.S. Geological Survey WaterResources Investigations Report 93-4152, 14 p.

Westjohn, D.B., and Weaver, T.L., 1996, Hydrogeologic framework of Pennsylvanian and Late Mississippian rocks in the central Lower Peninsula of Michigan: U.S. Geological Survey Water-Resources Investigations Report 94-4107, 50 p.

Wheeler, M.L., 1967, Electric analog model study of the hydrology of the Saginaw Formation in the Lansing, Michigan area: East Lansing, Michigan State University, M.S. Dissertation, 74 p.

Wood, W.W., 1969, Geochemistry of ground water of the Saginaw Formation in the upper Grand River basin, Michigan: East Lansing, Michigan State University, Ph.D. dissertation, $104 \mathrm{p}$.

Yeh, W. W-G., 1986, Review of parameter identification procedures in groundwater hydrology--the inverse problem: Water Resources Research, v. 22, no. 2, p. 95-108. 